Prepared in cooperation with the Texas Water Development Board and the Galveston Bay Estuary Program

\title{
Characterization of Streamflow, Suspended Sediment, and Nutrients Entering Galveston Bay from the Trinity River, Texas, May 2014-December 2015
}

Scientific Investigations Report 2016 $=5177$ 
Cover. U.S. Army Corps of Engineers navigational locks near U.S. Geological Survey streamflow-gaging station 08067252 Trinity River at Wallisville, Texas. 


\section{Characterization of Streamflow, Suspended Sediment, and Nutrients Entering Galveston Bay from the Trinity River, Texas, May 2014-December 2015}

By Zulimar Lucena and Michael T. Lee

Prepared in cooperation with the Texas Water Development Board and the Galveston Bay Estuary Program

Scientific Investigations Report 2016-5177 


\section{U.S. Department of the Interior SALLY JEWELL, Secretary}

\section{U.S. Geological Survey Suzette M. Kimball, Director}

\section{U.S. Geological Survey, Reston, Virginia: 2017}

For more information on the USGS - the Federal source for science about the Earth, its natural and living resources, natural hazards, and the environment—visit http://www.usgs.gov or call 1-888-ASK-USGS.

For an overview of USGS information products, including maps, imagery, and publications, visit http://store.usgs.gov.

Any use of trade, firm, or product names is for descriptive purposes only and does not imply endorsement by the U.S. Government.

Although this information product, for the most part, is in the public domain, it also may contain copyrighted materials as noted in the text. Permission to reproduce copyrighted items must be secured from the copyright owner.

Suggested citation:

Lucena, Zulimar, and Lee, M.T., 2017, Characterization of streamflow, suspended sediment, and nutrients entering Galveston Bay from the Trinity River , Texas, May 2014-December 2015: U.S. Geological Survey Scientific Investigations Report 2016-5177, 38 p., https://doi.org/10.3133/sir20165177.

ISSN 2328-031X (print)

ISSN 2328-0328 (online)

ISBN 978-1-4113-4107-4 


\section{Contents}

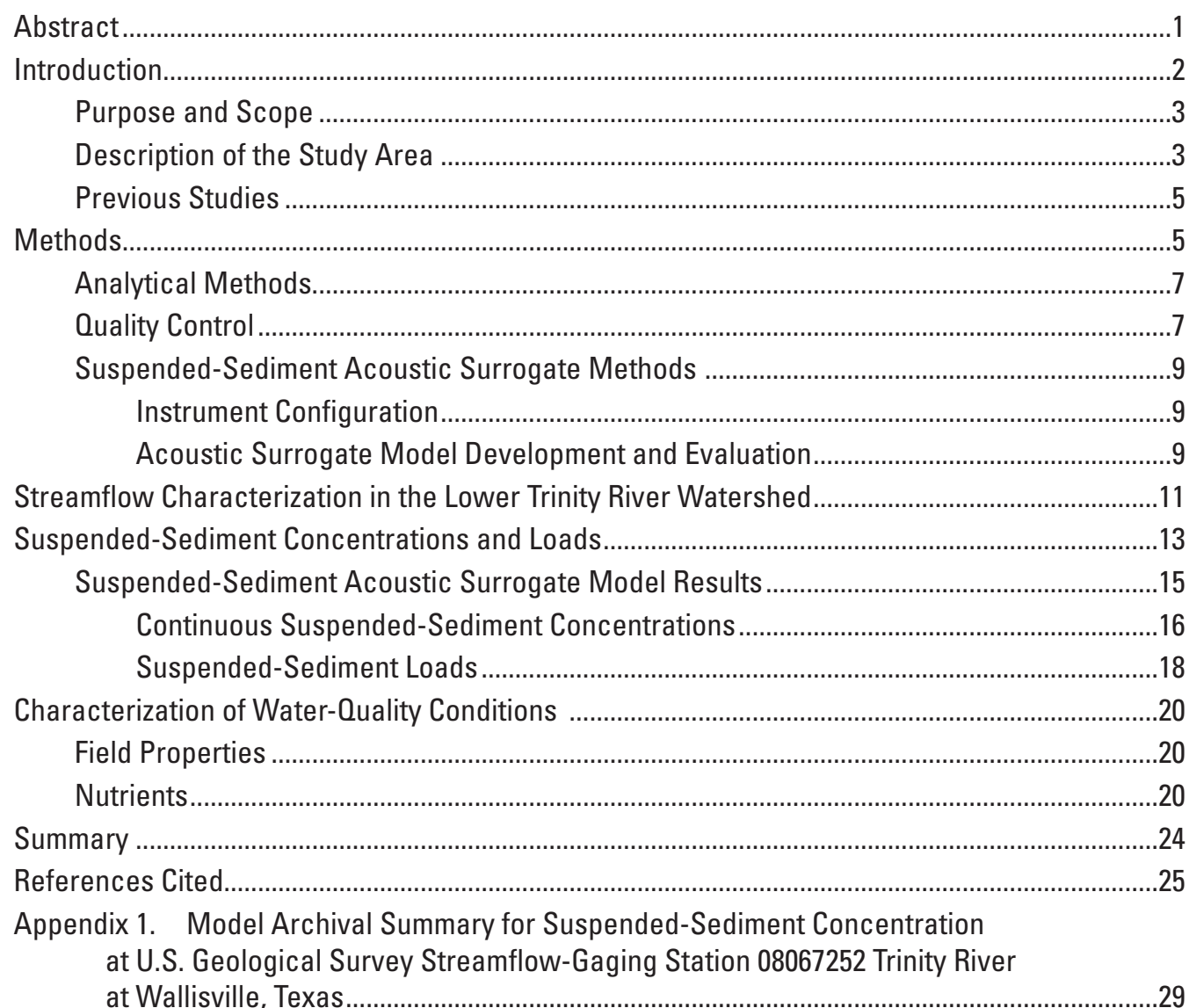

\section{Figures}

1. Map showing location of monitoring sites in the lower Trinity River watershed downstream from Lake Livingston, Texas

2. Map showing wetland cover and classification in the lower Trinity River watershed downstream from Lake Livingston, Texas

3. Photographs showing the $A$, data collection platform and $B$, Acoustic Doppler velocity meter installed at U.S. Geological Survey streamflow-gaging station 08067252 Trinity River at Wallisville, Texas

4. Graph showing annual daily mean discharge at U.S. Geological Survey streamflowgaging station 08066250 Trinity River near Goodrich, Texas, 1966-2015

5. Graph showing instantaneous discharge at U.S. Geological Survey streamflowgaging stations in the lower Trinity River watershed, Texas, May 2014December 2015

6. Graph showing discharge-duration curve indicating the streamflow at which each sample was collected at U.S. Geological Survey streamflow-gaging station 08067252 Trinity River at Wallisville, Texas, May 2014-December 2015.. 
7. Graph showing relation between sand-fine separation results and discharge measured at U.S. Geological Survey streamflow-gaging station 08067252

Trinity River at Wallisville, Texas, May 2014-December 2015.

8. Estimated suspended-sediment concentrations for residual plot and normal probability plot for a multiple linear regression model developed for the Trinity River at U.S. Geological Survey streamflow-gaging station 08067252 Trinity River at Wallisville, Texas, May 2014-December 2015

9. Graph showing estimated and measured suspended-sediment concentrations determined from a multiple linear regression model at U.S. Geological Survey streamflow-gaging station 08067252 Trinity River at Wallisville, Texas.

10. Example of acoustic backscatter profiles from Acoustic Doppler current profiler showing backscatter distributions in cross sections at discharges of 2,370 cubic feet per second $\left(\mathrm{ft}^{3} / \mathrm{s}\right)$, and $13,700 \mathrm{ft}^{3} / \mathrm{s}$

11. Graph showing suspended-sediment concentrations estimated by using a regression model developed for the Trinity River at U.S. Geological Survey streamflow-gaging station 08067252 Trinity River at Wallisville, Texas, January-December 2015.

12. Graph showing estimated monthly suspended-sediment loads at U.S. Geological Survey streamflow-gaging station 08067252 Trinity River at Wallisville, Texas, May 2014-December 2015

13. Graphs showing time series depicting concentrations of total nitrogen; total phosphorus; and associated daily mean discharge for samples collected at U.S. Geological Survey streamflow-gaging station 08067252 Trinity River at Wallisville, Texas, May 2014-December 2015.

14. Graph showing percentages of nitrogen constituents in water-quality samples collected at U.S. Geological Survey streamflow-gaging station 08067252 Trinity River at Wallisville, Texas, May 2014-December 2015

15. Graph showing relation between phosphorus concentrations and suspendedsediment concentrations at U.S. Geological Survey streamflow-gaging station 08067252 Trinity River at Wallisville, Texas, May 2014-December 2015.

1-1. Streamflow and sediment corrected backscatter duration curves at U.S. Geological Survey streamflow-gaging station 08067252 Trinity River at Wallisville, Texas, May 2014-December 2015

1-2. Diagnostics plots for selected regression model developed for U.S. Geological Survey streamflow-gaging station 08067252 Trinity River at Wallisville, Texas.

1-3. Model predicted and measured suspended-sediment concentrations at U.S. Geological Survey streamflow-gaging station 08067252 Trinity River at Wallisville, Texas.

1-4. Continuous suspended-sediment concentration record at U.S. Geological Survey streamflow-gaging station 08067252 Trinity River at Wallisville, Texas, January-December 2015 


\section{Tables}

1. Description of monitoring sites in the lower Trinity River watershed downstream from Lake Livingston, Texas, May 2014-December 2015.

2. Analytes measured, sample treatment and preservation, analytical methods, and reporting limits for samples collected at U.S. Geological Survey streamflowgaging station 08067252 Trinity River at Wallisville, Texas

3. Peak discharges measured at U.S. Geological Survey streamflow-gaging stations in the lower Trinity River watershed, Texas, May 2014-December 2015.

4. Results from suspended-sediment size analysis for selected samples in U.S. Geological Survey streamflow-gaging station 08067252 Trinity River at Wallisville, Texas, April 3, 2015-June 10, 2015

5. Summary of linear regression evaluation statistics for equation using discharge and sediment corrected backscatter to estimate suspendedsediment concentration in U.S. Geological Survey streamflow-gaging station 08067252 Trinity River at Wallisville, Texas, May 2014-December 2015.

6. Suspended-sediment load during high-flow events at U.S. Geological Survey streamflow-gaging station 08067252, Trinity River at Wallisville, Texas, May 2014December 2015.

7. Summary statistics for water-quality field properties measured at U.S. Geological Survey streamflow-gaging station 08067252 Trinity River at Wallisville, Texas, May 2014-December 2015

8. Summary statistics for nutrient parameters measured in the Trinity River at Wallisville, Texas, May 2014-December 2015......

1-1. Acoustic Doppler velocity meter specifications ..............................................................30

1-2. Acoustic Doppler velocity meter configuration settings. .................................................30

1-3. Summary statistics for suspended-sediment concentration data collected at U.S. Geological Survey streamflow-gaging station 08067252 Trinity River at Wallisville, Texas, May 2014-December 2015

1-4. Acoustic Doppler velocity meter settings used to process backscatter data with the Surrogate Analysis and Index Developer tool.

1-5. Alternatives models considered for estimating suspended-sediment concentrations at U.S. Geological Survey streamflow-gaging station 08067252 Trinity River at Wallisville, Texas.

1-6. Suspended-sediment regression model and nonparametric smearing bias correction factor for U.S. Geological Survey streamflow-gaging station 08067252 Trinity River at Wallisville, Texas

1-7. Summary statistics for the selected model and statistical measures to evaluate the suspended-sediment regression model for U.S. Geological Survey streamflowgaging station 08067252 Trinity River at Wallisville, Texas

1-8. Calibration data used for suspended-sediment model development at U.S.

Geological Survey streamflow-gaging station 08067252 Trinity River at Wallisville, Texas and selected statistical results. 


\section{Conversion Factors}

U.S. customary units to International System of Units

\begin{tabular}{|c|c|c|}
\hline Multiply & By & To obtain \\
\hline \multicolumn{3}{|c|}{ Length } \\
\hline inch (in.) & 25.4 & millimeter (mm) \\
\hline foot $(\mathrm{ft})$ & 0.3048 & meter $(\mathrm{m})$ \\
\hline mile (mi) & 1.609 & kilometer $(\mathrm{km})$ \\
\hline \multicolumn{3}{|c|}{ Area } \\
\hline square mile $\left(\mathrm{mi}^{2}\right)$ & 259.0 & hectare (ha) \\
\hline square mile $\left(\mathrm{mi}^{2}\right)$ & 2.590 & square kilometer $\left(\mathrm{km}^{2}\right)$ \\
\hline \multicolumn{3}{|c|}{ Volume } \\
\hline acre-foot (acre-ft) & 1,233 & cubic meter $\left(\mathrm{m}^{3}\right)$ \\
\hline \multicolumn{3}{|c|}{ Flow rate } \\
\hline foot per second (ft/s) & 0.3048 & meter per second $(\mathrm{m} / \mathrm{s})$ \\
\hline cubic foot per second $\left(\mathrm{ft}^{3} / \mathrm{s}\right)$ & 0.02832 & cubic meter per second $\left(\mathrm{m}^{3} / \mathrm{s}\right)$ \\
\hline \multicolumn{3}{|c|}{ Mass } \\
\hline ton, short $(2,000 \mathrm{lb})$ & 0.9072 & metric ton $(\mathrm{t})$ \\
\hline
\end{tabular}

International System of Units to U.S. customary units

\begin{tabular}{lll}
\hline \multicolumn{1}{c}{ Multiply } & \multicolumn{1}{c}{ By } & \multicolumn{1}{c}{ To obtain } \\
\hline \multicolumn{2}{c}{ Length } \\
\hline millimeter $(\mathrm{mm})$ & 0.03937 & inch (in.) \\
meter $(\mathrm{m})$ & 3.281 & foot (ft) \\
\hline
\end{tabular}

Temperature in degrees Celsius $\left({ }^{\circ} \mathrm{C}\right)$ may be converted to degrees Fahrenheit $\left({ }^{\circ} \mathrm{F}\right)$ as follows: ${ }^{\circ} \mathrm{F}=\left(1.8 \times{ }^{\circ} \mathrm{C}\right)+32$.

\section{Datum}

Horizontal coordinate information is referenced to the North American Datum of 1983 (NAD 83) and the North American Datum of 1927 (NAD 27).

\section{Supplemental Information}

Specific conductance is given in microsiemens per centimeter at 25 degrees Celsius $\left(\mu \mathrm{S} / \mathrm{cm}\right.$ at $\left.25^{\circ} \mathrm{C}\right)$.

Concentrations of chemical constituents in water are given in milligrams per liter (mg/L). 


\section{Abbreviations}

ADVM Acoustic Doppler velocity meter

BCF bias correction factor

EDI equal discharge increment

MAPE mean absolute percent error

NWIS National Water Information System

$\mathrm{R}^{2} \quad$ coefficient of determination

$\mathrm{R}^{2} \quad$ adjusted coefficient of determination

RMSE root mean square error

RPD relative percent difference

$\overline{S C B} \quad$ sediment corrected backscatter

SSL suspended-sediment load

VIF variance inflation factor 



\title{
Characterization of Streamflow, Suspended Sediment, and Nutrients Entering Galveston Bay from the Trinity River, Texas, May 2014-December 2015
}

\author{
By Zulimar Lucena and Michael T. Lee
}

\begin{abstract}
The U.S. Geological Survey (USGS), in cooperation with the Texas Water Development Board and the Galveston Bay Estuary Program, collected streamflow and water-quality data at USGS streamflow-gaging stations in the lower Trinity River watershed from May 2014 to December 2015 to characterize and improve the current understanding of the quantity and quality of freshwater inflow entering Galveston Bay from the Trinity River. Continuous streamflow records at four USGS streamflow-gaging stations were compared to quantify differences in streamflow magnitude between upstream and downstream reaches of the lower Trinity River. Water-quality conditions were characterized from discrete nutrient and sediment samples collected over a range of hydrologic conditions at USGS streamflow-gaging station 08067252 Trinity River at Wallisville, Tex. (hereinafter referred to as the "Wallisville site"), approximately 4 river miles upstream from where the Trinity River enters Galveston Bay.

Based on streamflow records, annual mean outflow from Livingston Dam into the lower Trinity River was 2,240 cubic feet per second $\left(\mathrm{ft}^{3} / \mathrm{s}\right)$ in 2014 and 22,400 $\mathrm{ft}^{3} / \mathrm{s}$ in 2015, the second lowest and the highest, respectively, during the entire period of record (1966-2015). During this study, only about 54 percent of the total volume measured at upstream sites was accounted for at the Wallisville site as the Trinity River enters Galveston Bay. This difference in water volumes between upstream sites and the Wallisville site indicates that at high flows a large part of the volume released from Lake Livingston does not reach Galveston Bay through the main channel of the Trinity River. These findings indicate that water likely flows into wetlands and water bodies surrounding the main channel of the Trinity River before reaching the Wallisville site and is being stored or discharged through other channels that flow directly into Galveston Bay.

To characterize suspended-sediment concentrations and loads in Trinity River inflow to Galveston Bay, a regression model was developed to estimate suspended-sediment concentrations by using acoustic backscatter data as a surrogate.
\end{abstract}

The model yielded an adjusted coefficient of determination value of 0.92 and a root mean square error of 1.65 milligrams per liter $(\mathrm{mg} / \mathrm{L})$. The mean absolute percentage error between measured and estimated suspended-sediment concentration was 35 percent. During this study, estimated suspendedsediment concentrations ranged from 2 to $701 \mathrm{mg} / \mathrm{L}$, with a mean of $97 \mathrm{mg} / \mathrm{L}$. Suspended-sediment concentrations varied in response to changes in discharge, with peak suspendedsediment concentrations occurring 1 to 2 days before the peak discharge for each event. The total suspended-sediment load at the Wallisville site during May 2014-December 2015 was approximately $2,200,000$ tons, with a minimum monthly suspended-sediment load of 100 tons in October 2014 and a maximum monthly load of 441,000 tons in November 2015.

Results from nutrient samples collected at the Wallisville site indicate that total nitrogen and total phosphorus concentrations fluctuated at a similar rate, with the highest nutrient concentrations occurring during periods of high flow corresponding to releases from Lake Livingston. The mean concentrations of total nitrogen and total phosphorus were approximately 75 percent higher during high flow releases than during periods of low flow, overshadowing variations in nutrient concentrations caused by seasonality at the Wallisville site.

Results from the study indicate nutrient delivery to Galveston Bay from the main channel of the Trinity River is likely controlled primarily by high-flow releases from Lake Livingston. For most samples collected at the Wallisville site, organic nitrogen was the predominant form of nitrogen; however, when discharge increased because of releases from Lake Livingston, the percentage of organic nitrogen typically decreased and the percentage of nitrate increased. The concentrations of total phosphorus also increased during high-flow events, likely as a result of suspended sediment within Lake Livingston releases and mobilization of sediment particles in the river channel and flood plain during these periods of high flow. The predominant source of phosphorous to Galveston Bay from the Trinity River is in particulate form closely tied to suspended-sediment concentrations. The changes in nutrient concentration and composition caused by releases from Lake 
Livingston during this study indicate the reservoir may play an important role in the delivery of nutrients into Galveston Bay. Further study is required to better understand the processes in Lake Livingston influencing the characteristics of nutrient and sediment inflow to Galveston Bay. With phosphorous concentrations correlated to suspended-sediment concentrations (coefficient of determination value of 0.75 ) and with the concentrations of nutrients changing as the discharge changes, the diversion of water and suspended sediment into surrounding wetlands and channels outside of the main channel of the Trinity River may play a large role in regulating nutrient inputs into Galveston Bay.

\section{Introduction}

Estuarine ecosystems such as Galveston Bay on the Texas Gulf Coast depend on freshwater inflows to maintain adequate levels of salinity, nutrients, and sediment to support healthy ecosystem function and diverse biological communities. The delivery of freshwater into estuaries may be affected by alterations in the river course, including channelization and dam construction, resulting in changes in sedimentation patterns and biogeochemistry (Sklar and Browder, 1998). In Texas, the quantity of water flowing to the bays and estuaries is often influenced by withdrawals, diversions, and retention. The volume and timing of freshwater inflow typically influence nutrient and sediment loading into estuaries, affecting ecosystem communities (Sklar and Browder, 1998; Kimmerer, 2002). During periods of reduced freshwater inflow or drought, primary production and the trophic structure in estuarine systems can be altered as a result of changes in salinity, nutrient loading, or increased light penetration from reduced sediment input (Montagna and Kalke, 1992; Livingston and others, 1997). Reduced sediment supply can also result in degradation and morphologic shifts in deltaic environments (Yang and Others, 2011), particularly when coupled with erosion, sea level rise (Lester and Gonzalez, 2011), and subsidence (Kennish, 2002). Increased sediment and nutrient loading to estuaries can also have detrimental effects in coastal systems. Excess sediment supply to estuarine systems increases turbidity and reduces light penetration (Harding and others, 1986; Cloern, 1987), limiting primary production. Nutrient enrichment in estuaries can cause an increase in the biomass of phytoplankton and algae, shifts in phytoplankton and animal species composition, and nuisance or toxic algal blooms (Smith and others, 1999; Kennish, 2002; Bricker and others, 2008).

The delivery of nutrients to coastal ecosystems has varied historically on a global basis and depends on several physical and biogeochemical factors. Galloway and others (2004) estimated that global nitrogen riverine export to the coast increased by approximately 78 percent between 1860 and the early 1990s primarily as a result of anthropogenic influences. In 1995, the human-induced contribution to total river nitrogen export was estimated to be 37 percent, an increase of
11 percent since 1970 (Bouwman and others, 2005). Nitrogen transported to streams from diffuse and point sources can be retained, transformed into other forms of nitrogen, or removed through physical and biogeochemical processes, such as assimilative uptake of nitrogen and denitrification of nitrate, before reaching the coastal environment (Alexander and others, 2000; Hamilton and others, 2001; Peterson and others, 2001). Seitzinger and others (2005) estimated that approximately 38 percent and 41 percent of the total nitrogen transported to coastal ecosystems from riverine systems in North America are in the forms of dissolved inorganic nitrogen and dissolved organic nitrogen, respectively. The sources of dissolved inorganic nitrogen are mostly anthropogenic nonpoint sources (fertilizers, agricultural fixation, and manure), whereas sources of dissolved organic nitrogen are predominantly natural. Seitzinger and others (2005) also estimated that approximately 82 percent of phosphorus delivered to estuaries from riverine systems in North America occurs in particulate form. Phosphorus has a strong affinity to sediment particulates; therefore, a large amount of the phosphorus load transported in riverine systems is attached to soil particles delivered in surface runoff (Mainstone and Parr, 2002). As a result, phosphorus transport is highest during rainfall events that produce runoff and during periods of high river discharge, when deposition and resuspension of sediment particles from the streambed result in transfer of phosphorus between the water column and the streambed. Other processes, such as adsorption and desorption reactions, are also important mechanisms that influence the concentrations of dissolved and particulate phosphorus in the water column (Sharpley and others, 1981; House, 2003) and phosphorus export to bays and estuaries.

As the largest and most biologically productive estuary in Texas, Galveston Bay is an important resource with a number of environmental challenges, many of which pertain directly or indirectly to the inflows from the heavily populated Trinity River watershed (Galveston Bay Estuary Program, 2016). The ability to accurately estimate the loads of sediment and nutrients entering Galveston Bay from the Trinity River watershed depends on accurate estimates of freshwater inflows and the concentrations of suspended sediment and nutrients associated with those inflows. Population and water demand are projected to continue to increase rapidly in the Trinity River watershed (Texas Water Development Board, 2016), underscoring the need for accurate streamflow, nutrient, and sediment load data. Available data on sediment and nutrient loads in the lower reaches of the Trinity River are scant, and the majority of water-quality samples have been collected in reaches of the river located 30 to 75 river miles upstream from where the river empties into Galveston Bay. To obtain better estimates of the nutrients and sediment entering Galveston Bay from the Trinity River, the U.S. Geological Survey (USGS), in cooperation with the Texas Water Development Board and the Galveston Bay Estuary Program, collected water-quality samples during May 2014-December 2015 at USGS streamflow-gaging station 08067252 Trinity River at Wallisville, Tex. (hereinafter referred to as the "Wallisville site"), approximately 4 miles 
upstream from Galveston Bay. Backscatter data from an Acoustic Doppler velocity meter (ADVM) were also collected and used in a regression model as a surrogate for suspendedsediment concentrations. Surrogate regressions provide an opportunity to obtain data of increased temporal resolution, allowing more accurate estimates of suspended-sediment concentrations and loads compared to discrete water-quality samples.

\section{Purpose and Scope}

This report documents and characterizes freshwater streamflow volume, nutrient concentrations, and sediment concentrations and loads entering Galveston Bay through the main channel of the Trinity River watershed during May 2014-December 2015. Continuous streamflow records from four USGS streamflow-gaging stations are compared to assess changes in streamflow magnitude and to quantify discrepancies in streamflow between upstream and downstream reaches of the Trinity River separated by Lake Livingston. Water quality is characterized from discrete nutrient and sediment samples collected at the Wallisville site over a range of hydrologic conditions. Techniques used to collect and analyze these samples are documented. This report also describes a regression model developed to estimate suspended-sediment concentrations and loads from discharge and acoustic surrogate data in the lower reaches of the Trinity River and presents a continuous record of suspended-sediment concentrations and loads for the Wallisville site. This report helps address the need for discharge and water-quality data in the lower reaches of the Trinity River to improve the understanding of the volume and quality of freshwater inflow to Galveston Bay.

\section{Description of the Study Area}

Galveston Bay covers approximately 600 square miles $\left(\mathrm{mi}^{2}\right)$ and is the largest estuary in Texas (Lester and Gonzalez, 2011). Freshwater inflows into Galveston Bay originate from the Trinity and San Jacinto Rivers and smaller bayous and creeks. Estimates show that the Trinity River is the major source of inflow into Galveston Bay, contributing more than half of the total freshwater inflow (Lester and Gonzalez, 2011). The watershed of the Trinity River covers approximately $18,000 \mathrm{mi}^{2}$ and is the largest watershed entirely in Texas. From its headwaters near Dallas, Tex., the Trinity River flows approximately 715 miles before emptying into Galveston Bay (Trinity River Authority of Texas, 2012). The watershed of the Trinity River is typically divided into upper and lower parts delineated by Lake Livingston (fig. 1). Upstream from Lake Livingston, the Trinity River is hereinafter referred to as "upper Trinity River;" downstream from Lake Livingston, the Trinity River is hereinafter referred to as the "lower Trinity River." The flows in the lower Trinity River are regulated by continuous releases from Lake Livingston. During low-flow conditions in the extreme lowermost part of the Trinity River near Galveston Bay, tides control daily flow patterns (Texas Parks and Wildlife Department, 1974).

The USGS currently (2016) operates four streamflowgaging stations in the lower Trinity River watershed. These stations are: 08066250 Trinity River near Goodrich, Tex. (hereinafter referred to as "the Goodrich site"), 08066500 Trinity River at Romayor, Tex. (hereinafter referred to as "the Romayor site"), 08067000 Trinity River at Liberty, Tex. (hereinafter referred to as the "Liberty site"), and the Wallisville site (table 1). The Wallisville site is approximately 4 river miles upstream from where the Trinity River enters Galveston Bay. The Liberty site is approximately 30 river miles upstream from the Wallisville site; the Romayor site is approximately 40 river miles upstream from the Liberty site; and the Goodrich site is approximately 20 river miles upstream from the Romayor site. The Goodrich site is about 10 river miles downstream from the Livingston Dam.

Because of a lack of streamflow data in the lower reaches of the Trinity River before 2014, most estimates of freshwater inflow made prior to 2014 (Lee and others, 2001; Powell and others, 2002) relied upon data collected at the Romayor site (fig. 1, table 1). Discharge measurements made in the lower reaches of the Trinity River during high-flow events in 2009 and 2010 indicated discrepancies in discharge between the Romayor site and the lower reaches of the Trinity River (Lee, 2010). It is possible that the streamflow data from the Romayor site may not accurately represent the inflow from the main channel of the Trinity River to Galveston Bay. In 2014, the USGS installed an index-velocity gage in the lower reaches of the Trinity River at the Wallisville site to better estimate the inflow from the Trinity River into Galveston Bay and improve the understanding of streamflow patterns in the lower Trinity River watershed.

The lower Trinity River drains a low gradient watershed with land cover characterized by woody wetlands (29 percent), pasture (17 percent), and evergreen forest (13 percent) (Homer and others, 2015). South of the Liberty site, a system of wetlands and lakes are hydrologically connected to the main channel of the Trinity River (fig. 2). Old River Lake and Lost Lake form the nexus of a system of wetlands and lakes referred to in this report as the "Old River system." The Old River system diverges from the main Trinity River channel downstream from the Liberty site and upstream from Interstate 10 and rejoins the main channel of the Trinity River approximately 3 miles upstream from where the Trinity River empties into Galveston Bay. The two main types of wetlands connecting the main Trinity River channel with the Old River system upstream from Interstate 10 are classified as freshwater emergent and freshwater forested/shrub that are seasonally or temporarily flooded conditional to tides and streamflow (U.S. Fish and Wildlife Service, 2016). Near the Wallisville site, as the Trinity River empties into Galveston Bay, the wetlands form a delta consisting of estuarine intertidal and marine wetlands. The Old River system is also hydrologically connected to these estuarine and marine wetlands in the delta adjacent to Galveston Bay. 


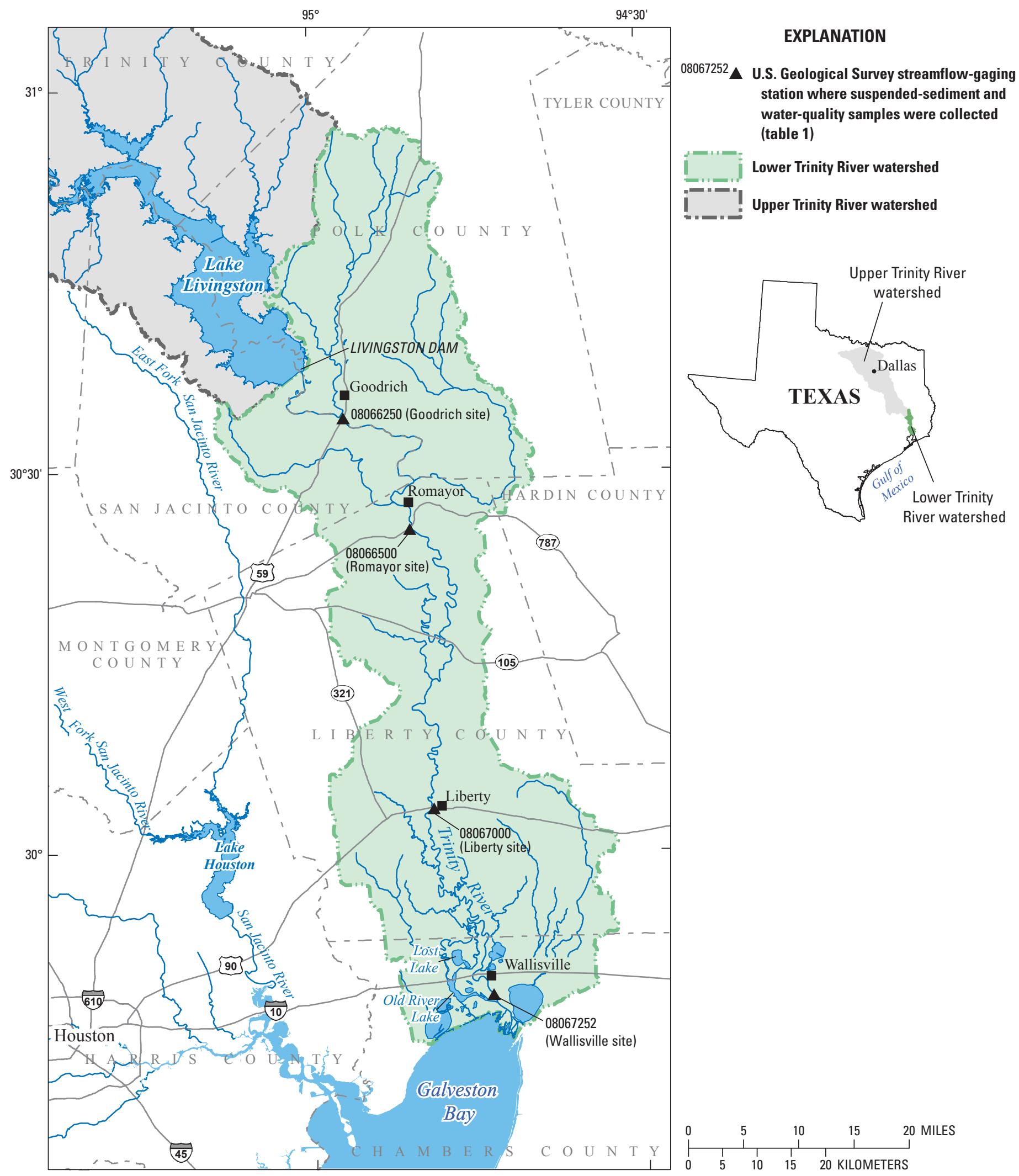

Base modified from U.S. Geological Survey digital data, various scales USA Contiguous Albers Equal Area Projection North American Datum 1983

Figure 1. Location of monitoring sites in the lower Trinity River watershed downstream from Lake Livingston, Texas. 
Table 1. Description of monitoring sites in the lower Trinity River watershed downstream from Lake Livingston, Texas, May 2014-December 2015.

[USGS, U.S. Geological Survey]

\begin{tabular}{cllccc}
\hline $\begin{array}{c}\text { USGS sta- } \\
\text { tion number } \\
\text { (fig. 1) }\end{array}$ & \multicolumn{1}{c}{ USGS station name } & $\begin{array}{c}\text { Short name } \\
\text { (fig. 1) }\end{array}$ & $\begin{array}{c}\text { Latitude } \\
\text { (degrees, min- } \\
\text { utes, seconds) }\end{array}$ & $\begin{array}{c}\text { Longitude } \\
\text { (degrees, min- } \\
\text { utes, seconds) }\end{array}$ & $\begin{array}{c}\text { Drainage area } \\
\text { (square miles) }\end{array}$ \\
\hline 08066250 & Trinity River near Goodrich, Texas & Goodrich site & $30^{\circ} 34^{\prime} 19^{\prime \prime}$ & $94^{\circ} 56^{\prime} 55^{\prime \prime}$ & 16,844 \\
08066500 & Trinity River at Romayor, Texas & Romayor site & $30^{\circ} 25^{\prime} 30^{\prime \prime}$ & $94^{\circ} 51^{\prime} 02^{\prime \prime}$ & 17,186 \\
08067000 & Trinity River at Liberty, Texas & Liberty site & $30^{\circ} 03^{\prime} 27^{\prime \prime}$ & $94^{\circ} 49^{\prime} 05^{\prime \prime}$ & 17,468 \\
08067252 & Trinity River at Wallisville, Texas & Wallisville site & $29^{\circ} 48^{\prime} 44^{\prime \prime}$ & $94^{\circ} 43^{\prime} 52^{\prime \prime}$ & 17,796 \\
\hline
\end{tabular}

\section{Previous Studies}

In 2009, the U.S. Geological Survey, in cooperation with the Texas Water Development Board, began evaluating the variability of sediment and nutrient characteristics in the lower reaches of the Trinity River during a variety of hydrologic conditions. High-flow events were evaluated to demonstrate the variability of sediment and nutrient characteristics caused by differences in flood-discharge magnitude and duration. During high-flow events, discharge was measured at the Wallisville site; however, maximum measured discharge was approximately 35 to 50 percent lower than the discharge computed at upstream streamflow-gaging stations (Lee, 2010). The overall decrease in flow observed at the Wallisville site compared to the flow at upstream streamflow-gaging stations could possibly be attributed to the distribution of water into the wetlands surrounding the river as water levels in high-flow events overtopped the banks of the main channel of the lower Trinity River. Two scenarios could have occurred: (1) water was temporarily stored in wetlands and gradually released to the main channel of the Trinity River when flows were receding or (2) water was directly discharged into Galveston Bay through channels in the delta. If scenario 1 occurred, a continuous record of discharge would show longer periods of high flow in the lower reaches of the Trinity River and a total water volume similar to the volume observed in upstream streamflow-gaging stations. If scenario 2 occurred, a hydrograph would follow a streamflow pattern similar to those observed at upstream streamflow-gaging stations, but discharge and total volume would be of lower magnitude. Each scenario would have potentially different resulting loads of sediment and nutrients ultimately reaching the Galveston Bay ecosystem. Because of these findings, an index-velocity gage was installed in 2014 at the Wallisville site to examine the hydrodynamics in the extreme low reaches of the Trinity River.

\section{Methods}

Discharge, stage, and water-velocity data at the Goodrich, Romayor, Liberty, and Wallisville sites were collected according to USGS methods described by Rantz and others (1982a, b), Sauer and Turnipseed (2010), Levesque and Oberg (2012), and Mueller and others (2013). Discharge at the Goodrich, Romayor, and Liberty gages was computed using stage-discharge rating techniques (Rantz and others, 1982a, b; Sauer and Turnipseed, 2010). At the Wallisville site, discharge was computed by using index-velocity rating techniques (Levesque and Oberg, 2012). The index-velocity method allows the computation of discharge at streamflow-gaging stations where a rating cannot be solely based on stage, such as the tidally affected flows at the Wallisville site. Discrete streamflow measurements were made at the Wallisville site with an acoustic Doppler current profiler according to methods described by Mueller and others (2013) during each visit prior to the collection of water-quality and sediment samples.

During May 2014-December 2015, 34 discrete waterquality samples were collected over a range of hydrologic conditions at the Wallisville site. Samples were analyzed for suspended-sediment concentration, total nitrogen, nitrate plus nitrite, nitrite, ammonia, total phosphorus, and orthophosphate; a sand-fine separation was done to determine the amounts of sand-sized suspended sediment (greater than 0.0625 and less than or equal to 2 millimeters [mm]) and finesized suspended sediment (less than or equal to $0.0625 \mathrm{~mm}$ ) (Guy, 1969).

Water-quality samples for the analysis of total nitrogen, nitrate plus nitrite, nitrite, ammonia, total phosphorus, and orthophosphate were collected at the Wallisville site in accordance with guidelines described in the USGS National Field Manual (U.S. Geological Survey, variously dated). Suspendedsediment samples were collected in accordance with USGS methods described in Edwards and Glysson (1999). During the collection of water-quality and sediment samples, a multiparameter water-quality sonde was used in the field to measure dissolved oxygen concentration, $\mathrm{pH}$, specific conductance, water temperature, and turbidity.

Water-quality and suspended-sediment samples were collected from a boat by either the equal discharge increment (EDI) or the multiple grab sample method (Edwards and Glysson 1999; U.S. Geological Survey, variously dated). When measured mean water velocity exceeded 1.5 feet per second $(\mathrm{ft} / \mathrm{s})$, EDI samples were collected using a cable-suspended 


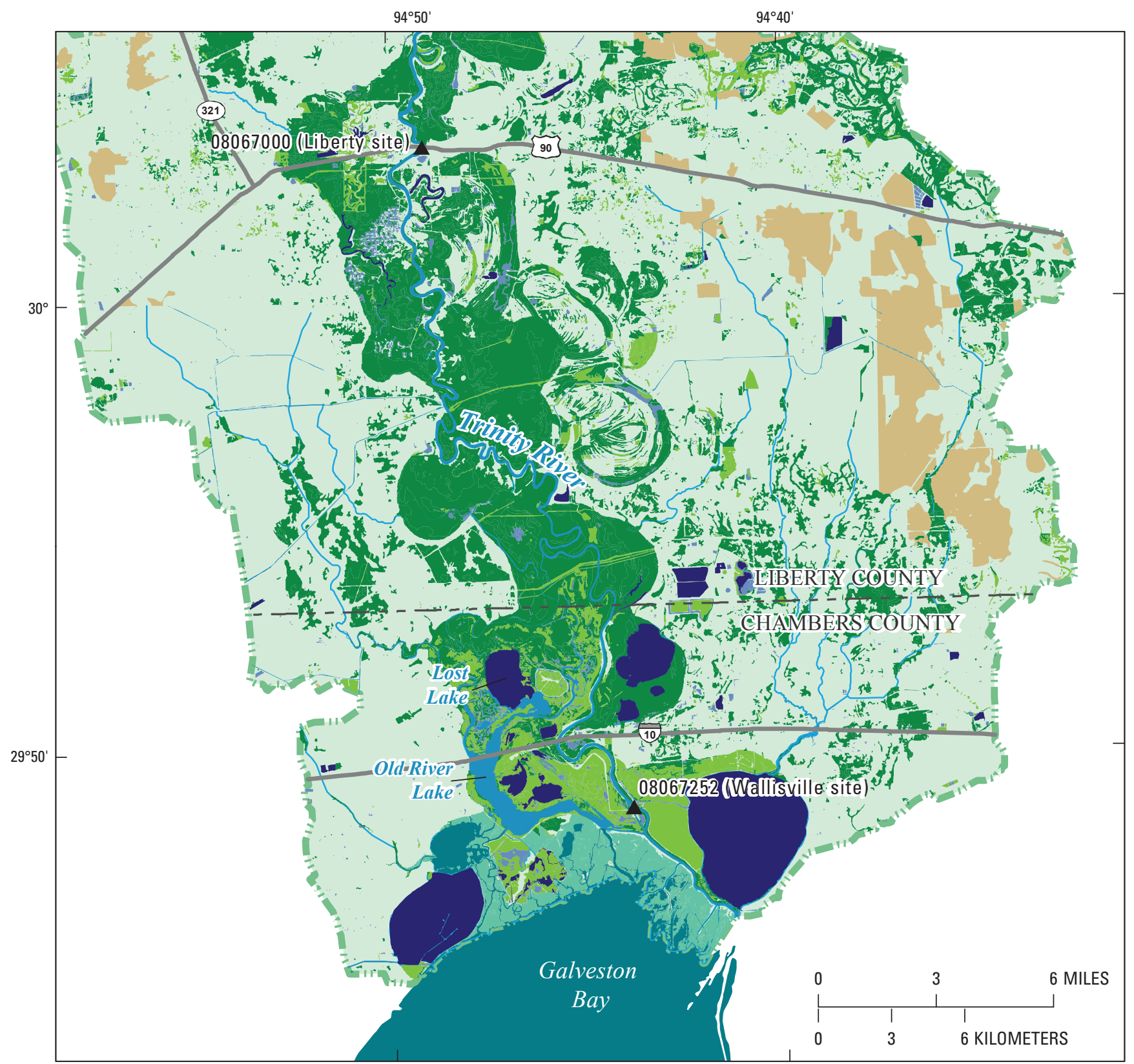

Base modified from U.S. Geological Survey

and U.S. Fish and Wildlife Service, various scales

USA Contiguous Albers Equal Area Projection

North American Datum 1983

\section{EXPLANATION}
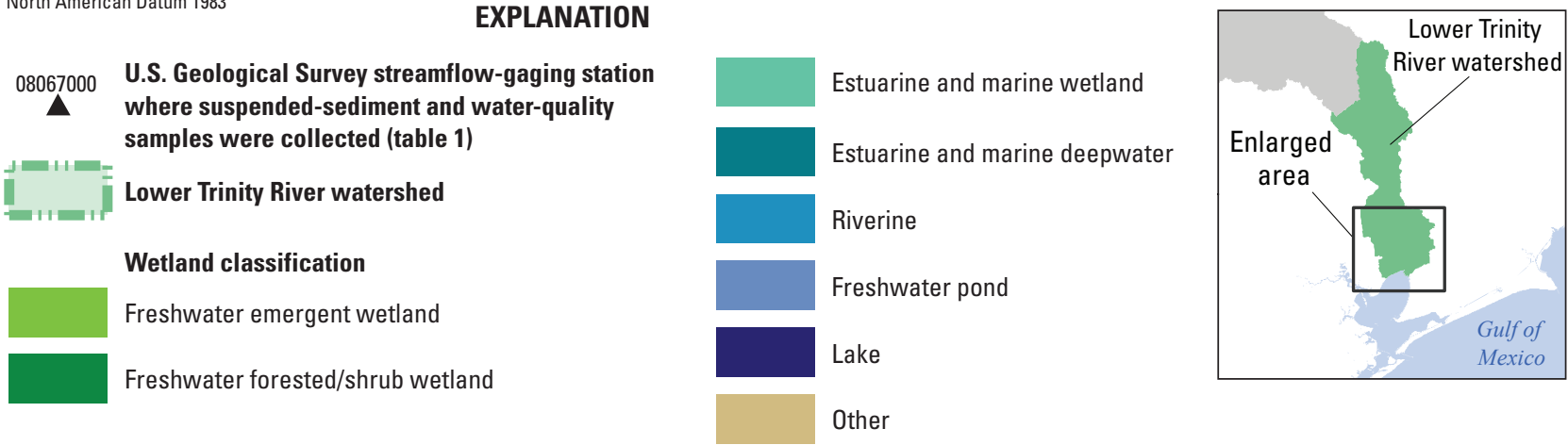

Figure 2. Wetland cover and classification in the lower Trinity River watershed downstream from Lake Livingston, Texas. 
US DH-2 sampler after dividing a cross section into five sections, each representing equal volumes of stream discharge. The EDI method allows the collection of an isokinetic depthintegrated sample that represents the discharge-weighted concentrations of the stream cross section being sampled. When measured mean water velocity was less than $1.5 \mathrm{ft} / \mathrm{s}$, nonisokinetic grab samples were collected at the center of five equal width sections using a weighted bottle sampler (U.S. Geological Survey, variously dated). Of the 34 collected samples, 16 were collected with the EDI method.

Water-quality and suspended-sediment samples for each vertical were composited in a polyethylene churn splitter and subsamples for unfiltered constituents were transferred into sample bottles while mixing at a constant rate. The use of a churn splitter can potentially bias suspended-sediment concentration because sand-sized particles (greater than or equal to $0.625 \mathrm{~mm}$ and smaller than $2.0 \mathrm{~mm}$ ) may not remain uniformly suspended in the churn while obtaining the sample aliquot (Capel and Larson, 1995; Horowitz and others, 1997). However, the accuracy is considered to be acceptable when the churn is used to split samples with particle sizes smaller than $0.250 \mathrm{~mm}$ and suspended-sediment concentration less than 1,000 mg/L (U.S. Geological Survey, variously dated). This potential bias was not expected to substantially influence suspended-sediment concentration results during this study because data from previous samples collected at the Wallisville site indicate fine particles (smaller than $0.0625 \mathrm{~mm}$ ) typically dominate the distribution of suspended-sediment size classes and because during high-flow events, suspendedsediment particles are usually fine sand particles (less than $0.250 \mathrm{~mm}$ ) or smaller. Water-quality samples for dissolved nutrients analysis were filtered using a 0.45 -micron $(\mu \mathrm{m})$ pore size capsule filter and decanted into sample bottles.

\section{Analytical Methods}

Samples for suspended-sediment concentration, sand-fine separation analysis, and full particle-size distribution analysis were shipped to the USGS Kentucky Water Science Center Sediment Laboratory in Louisville, Kentucky. Methods for sediment sample analyses are documented in Guy (1969). Samples for nutrient analysis were preserved, chilled, and shipped overnight to the National Water Quality Laboratory in Lakewood, Colorado, for analysis. Methods for nutrient analysis are documented in Fishman (1993), U.S. Environmental Protection Agency (1993), and Patton and Kryskalla (2003, 2011). Samples were analyzed for nutrients by using approved methods; the analysis method and method detection limit for each constituent are provided in table 2 . Water-quality data are stored in the National Water Information System (NWIS) database (U.S. Geological Survey, 2016) in accordance with USGS protocols.

Experiments at the USGS National Water Quality Laboratory in 2007 and 2009-10 indicate that the alkaline-persulfate digestion of whole water samples resulted in a potential negative bias in total nitrogen concentrations in the presence of suspended sediment (Rus and others, 2013). This negative bias may be site specific and varies in magnitude, depending on the origin and concentration of suspended sediment. At the time of this report (2016), the magnitude of potential bias is unknown at the Wallisville site, and the total nitrogen data from this study are reported as the minimum concentration of this constituent in each sample.

\section{Quality Control}

To evaluate the variability of sample processing and analysis in water-quality constituents, data from field replicate samples collected at the Wallisville site from 2009 to 2015 were used. The dataset consists of 17 split replicates, which are prepared from a single sample that is collected and then subdivided into two samples. Quality-control data collected outside of the study period can be used to increase the size of the dataset and improve the understanding of variability in the environmental data as long as the samples can be considered to be in same inference space (Mueller and others, 2015). It was determined that replicate samples collected at the Wallisville site prior to this study share the same inference space (Lorenzen and Anderson, 1993) as the samples collected during the study because they represent similar conditions in terms of potential variability. This assumption was based on (1) consistent sampling methods and equipment were used for the collection of all samples, (2) hydrologic conditions and concentrations in the quality-control dataset are representative of those observed during the study period, (3) analytical methods for most constituents did not change throughout the sampling period, and (4) sample collection and processing were conducted at the same location.

For nitrate plus nitrite, 4 out of the 17 replicate samples were used in the analysis because of a change in the analytical method in 2011, and because some results were less than the method detection limit, the "minimum concentration of a substance that can be measured and reported with 99 percent confidence that the analyte concentration is greater than zero" (Childress and others, 1999, p. 19). For the rest of the constituents, replicate samples were only used in the analysis when results were greater than or equal to the method reporting limit. 
Table 2. Analytes measured, sample treatment and preservation, analytical methods, and reporting limits for samples collected at U.S. Geological Survey streamflow-gaging station 08067252 Trinity River at Wallisville, Texas.

$\left[\mathrm{mg} / \mathrm{L}\right.$, milligrams per liter; $\mu \mathrm{m}$, micrometer; USGS, U.S. Geological Survey; NWQL, National Water Quality Laboratory; $\mathrm{H}_{2} \mathrm{SO}_{4}$, sulfuric acid ;USEPA, U.S. Environmental Protection Agency; mm, millimeter; WSC, Water Science Center; ASTM, American Society for Testing and Materials]

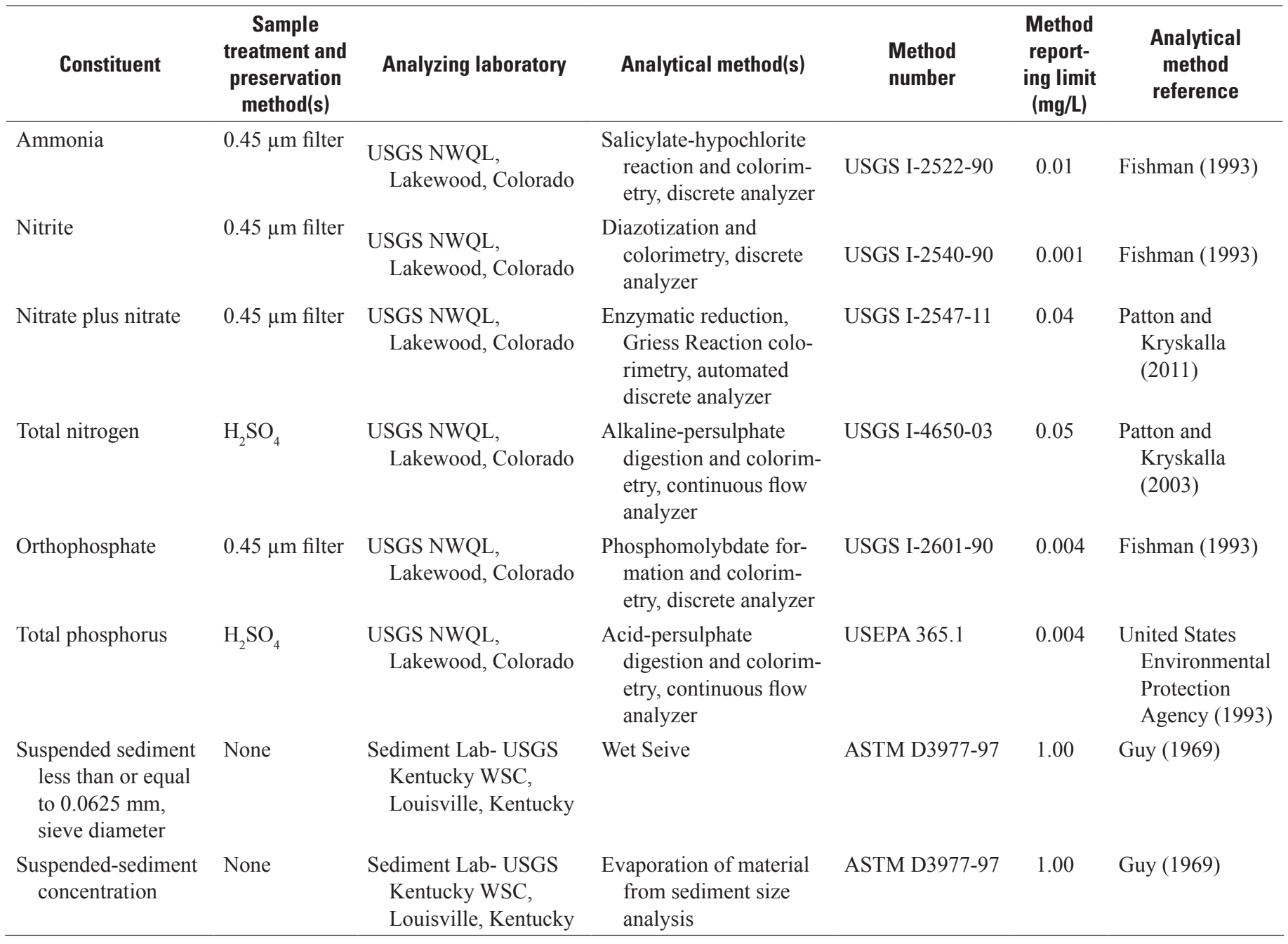


To determine variability in environmental samples, the relative percent difference (RPD) was calculated between each pair of duplicate analyses by the following equation

$$
R P D=\frac{\left|C_{1}-C_{2}\right|}{\left(C_{1}+C_{2}\right) / 2} \times 100,
$$

where

$$
\begin{aligned}
& C_{1} \quad \begin{array}{l}
\text { is the constituent concentration in the } \\
\text { environmental sample, and }
\end{array} \\
& C_{2} \quad \begin{array}{l}
\text { is the constituent concentration in the split } \\
\text { replicate sample. }
\end{array}
\end{aligned}
$$

The mean RPD of replicate concentrations was less than 9 percent for all analytes. This estimate, although low, is also conservative, because high RPD values from low concentration samples with a small absolute difference were used in the analysis. Overall, these replicate samples indicate low variability in nutrient and sediment analyses.

Equipment blanks were collected prior to the study period to determine potential contamination introduced to samples by personnel, sampling equipment, and shipping. The blanks were collected as part of the water-quality monitoring effort at the Wallisville site by using the same equipment that was used to collect environmental samples. Because analytical results for equipment blanks did not indicate that contamination affected environmental data, no additional equipment blanks were collected during the period of this study.

\section{Suspended-Sediment Acoustic Surrogate Methods}

Although Acoustic Doppler velocity meters are primarily used to measure water velocity, the acoustic backscatter measured by ADVMs makes them useful for computing suspended-sediment concentrations in streams. Acoustic backscatter increases as more particles are suspended in the water, reflecting the acoustic pulse emitted by the ADVM (Wood and Teasdale, 2013; Landers and others, 2016; Topping and Wright, 2016). Regression equations that contain acoustic backscatter, turbidity, or streamflow can be used to compute suspended-sediment concentrations at a high temporal resolution (typically every 15 minutes), providing an advantage over discrete suspended-sediment concentration samples. For example, during high-flow events, the concentrations of suspended-sediment can vary considerably within a short time. This temporal variability with discrete samples is difficult to capture because there are typically long gaps between sample collection and analysis. Discrete samples also provide information only for the time in which the sample was collected, resulting in interpolation between sampling points that may not accurately characterize variability in suspendedsediment concentrations.

\section{Instrument Configuration}

The data from an index-velocity gage installed at the Wallisville site, in accordance with USGS guidelines for streamflow and acoustic sediment surrogate data collection (Levesque and Oberg, 2012, Landers and others, 2016), were used to develop an acoustic surrogate for suspendedsediment concentration. The index-velocity gage consists of a 1.5-megahertz (MHz) SonTek Argonaut-SL (Side-Looker) ADVM (Xylem Analytics, 2016) bolted to a 2-inch diameter pipe (fig. 3). The pipe, which can be lowered and raised as needed to access the ADVM, is mounted vertically on the right bank with the ADVM at a fixed position perpendicular to flow. Power is provided by a marine battery charged by a 30 -watt solar panel installed above a gage house. The data are recorded every 15 minutes by a Sutron SatLink2-V2 Data Collection Platform and then transmitted every hour by antenna to the Geostationary Operational Environmental Satellite system, which transmits the data to a downlink at the USGS office for display on the Web and storage in the USGS NWIS database.

The Acoustic Doppler velocity meter is configured to measure velocity and acoustic backscatter as signal-to-noise ratio in five cells of equal size throughout a sample volume that extends from 10 to 60 feet ( $\mathrm{ft}$ ) from the instrument (15-20 percent of channel width). The range of the horizontal sample volume was determined after evaluating the acoustic data for interferences and obstructions along the beam path. This configuration was verified before each water-quality sample was collected to ensure no changes occurred in the sample volume that could affect acoustic backscatter data between site visits. Additional instrument setup details are included (app. 1).

Throughout the duration of the study, two averaging intervals were used to collect backscatter data during sample collection for model calibration. During May 16, 2014 January 15, 2015, acoustic backscatter measurements for the surrogate model calibration dataset were averaged over 10 minutes and reported every 15 minutes. Because discharge measurements for developing the index-velocity rating to estimate streamflow were being made concurrently with the collection of suspended-sediment concentration samples, for calibration samples collected during January 16, 2015December 31, 2015, acoustic backscatter measurements were averaged and recorded every 60 seconds as recommended by index-velocity rating guidelines (Levesque and Oberg, 2012).

\section{Acoustic Surrogate Model Development and Evaluation}

Prior to using acoustic backscatter measurements as input in a surrogate regression model, the raw measured acoustic backscatter data for each cell in the sample volume requires corrections for beam spreading and for acoustic attenuation as the sound signal is transmitted through the water and sediment (Landers and others, 2016). Raw measured acoustic 


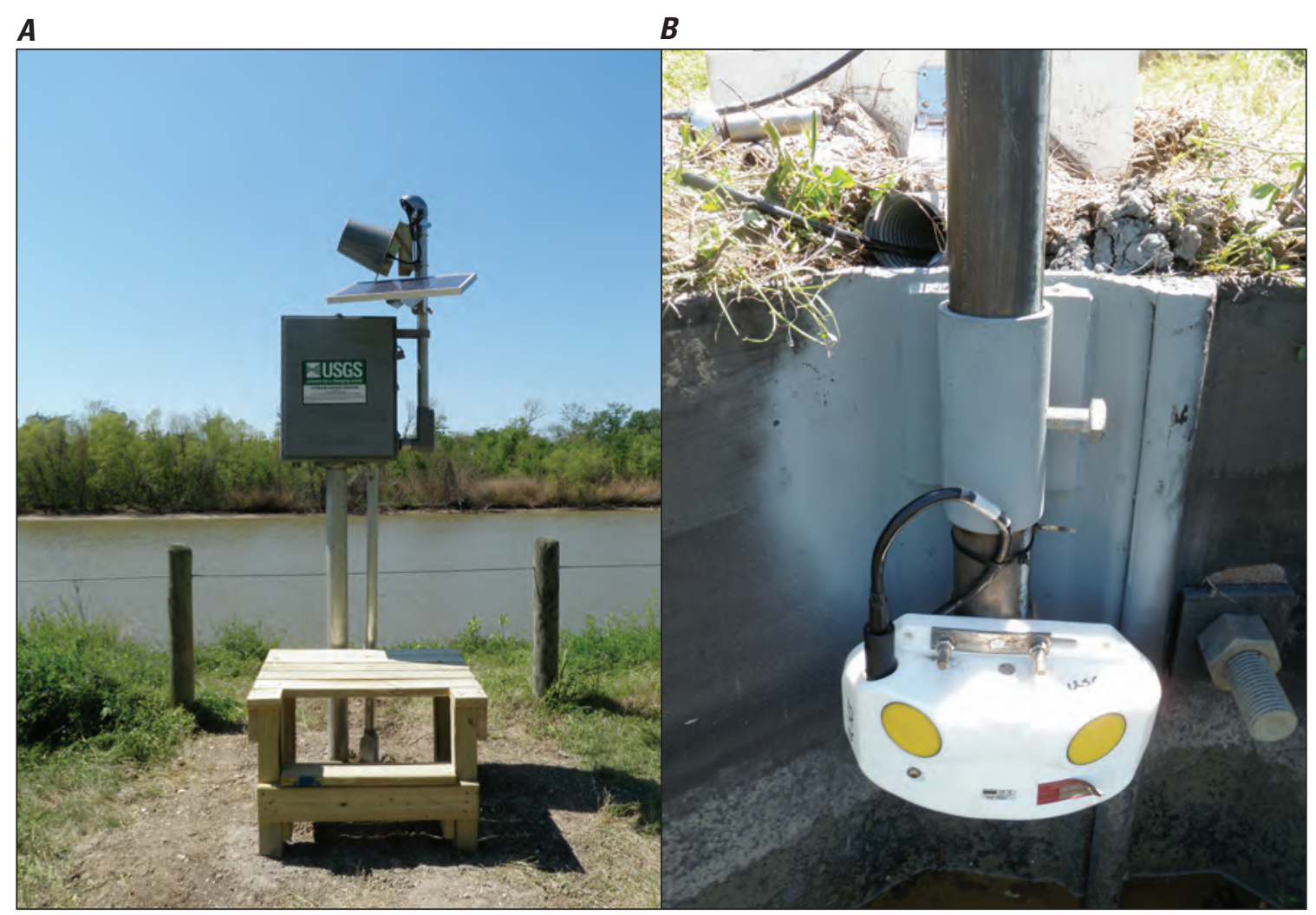

Figure 3. The $A$, data collection platform and $B$, Acoustic Doppler velocity meter installed at U.S. Geological Survey streamflow-gaging station 08067252 Trinity River at Wallisville, Texas.

backscatter (as signal-to-noise-ratio) for each cell was corrected and averaged by using methods described in Landers and others (2016). Data corrections produce a mean sediment corrected backscatter $(\overline{S C B})$ value, which is determined for each measurement in the dataset. The Surrogate Analysis and Index Developer (SAID) tool (Domanski and others, 2015), an application written for the evaluation of acoustic surrogates and the development of a suspended-sediment concentration rating based on acoustic backscatter data, was used to perform these corrections.

A sediment acoustic surrogate linear regression model was developed with suspended-sediment concentration data from discrete samples collected at the Wallisville site and continuous streamflow and corrected acoustic backscatter data recorded at the index-velocity gage. Thirty-one observations were used to calibrate the surrogate model. Although 35 suspended-sediment samples were collected, 2 were removed from the dataset because of data gaps in the acoustic backscatter time series, and 2 were removed because of potential issues with data quality indicated by outlier tests and further evaluation of field measurements. The calibration data, including removed data points, are provided (app. 1).

The SAID tool was used to match discrete suspended-sediment concentration samples with a concurrent measurement and develop an ordinary least squares regression model to predict suspended-sediment concentration from the resulting calibration dataset. Suspended-sediment concentration data were log transformed to improve distribution prior to being included in a regression model. The use of a $\log$ transformation introduces a bias when retransforming data to its original units. This bias was corrected with the nonparametric bias correction factor (BCF) introduced by Duan (1983). The equation to compute the BCF for log transformations is as follows:

$$
B C F=\frac{\sum_{i}^{n} 1^{10^{e_{i}}}}{n},
$$

where

$$
\begin{array}{ll}
n & \text { is the number of samples, and } \\
e_{i} & \text { is the residual, in log units. }
\end{array}
$$

Regression-estimated suspended-sediment concentrations were retransformed and then corrected for bias by multiplying concentrations by the $\mathrm{BCF}$.

The adjusted coefficient of determination $\left(\mathrm{R}_{\mathrm{a}}^{2}\right)$, root mean square error (RMSE), mean absolute percent error (MAPE), 
variance inflation factor (VIF), Cook's distance (Cook's D), and the difference in fit statistic (DFFITS) are some of the statistical measures used to evaluate the regression models in this report (Belsley and others, 1980; Mayer and Butler, 1993; Helsel and Hirsch, 2002). The coefficient of determination $\left(\mathrm{R}^{2}\right)$ is a value from 0 to 1 that describes the variability in the response explained by the regression model (Helsel and Hirsch, 2002). In multiple linear regression, $R^{2}$ will increase as additional explanatory variables are added to the model; thus adjusted $\mathrm{R}^{2}\left(\mathrm{R}_{\mathrm{a}}^{2}\right)$ was determined because this measure compensates for the number of explanatory variables and allows the comparison of models that have different numbers of explanatory variables. The RMSE of the regression is a measure of the variance between regression-computed and measured values (Chai and Draxler, 2014). The RMSE is expressed in the same units as the response variable, which in this case is milligrams per liter once retransformed from $\log _{10}$ Also, as another measure to assess the differences between regression-computed and measured suspendedsediment concentration, the mean absolute percent error (MAPE) (Mayer and Butler, 1993) was determined using the following equation:

$$
M A P E=\frac{100}{n} \sum_{i}^{n}\left|\frac{S S C_{M i}-S S C_{E i}}{S S C_{M i}}\right|,
$$

where

$$
\begin{aligned}
n & \text { is the number of samples, } \\
S S C_{M i} & \text { is the measured suspended-sediment } \\
& \text { concentration, and, } \\
S S C_{E i} & \text { is the regression-computed suspended- } \\
& \text { sediment concentration. }
\end{aligned}
$$

Models with more than one predictive variable were evaluated for multicollinearity to determine if the predictive variables showed any correlation between each other, because this can result in undesirable consequences when making inferences about the model (Helsel and Hirsch, 2002). The variance inflation factor (VIF) was used to measure multicollinearity. An ideal VIF is close to 1 , whereas a VIF larger than 10 indicates multicollinearity between variables and that either variable would explain about the same amount of variability (Helsel and Hirsch, 2002). Cook's D and DFFITS measure the influence of individual observations on the regression equation; compared to other observations that plot more closely to the regression line, those with high leverage, which are large outliers, exert a stronger influence on the position of the regression line (Helsel and Hirsch, 2002, p. 248). To verify if the selected model met assumptions of constant variance and normality of residuals, residuals were plotted against estimated suspended-sediment concentration to determine any issues of nonconstant variance and on a normal-probability plot to evaluate normality of residuals (Helsel and Hirsch, 2002).

\section{Streamflow Characterization in the Lower Trinity River Watershed}

Streamflow measured at the Goodrich site corresponds to outflow from Lake Livingston into the Trinity River. Annual daily mean discharge (annual mean discharge) has been determined for each calendar year since the Goodrich site was installed. The annual mean discharge at the Goodrich site has varied during the 50-year period of record since the start of data collection in 1966; the long-term annual discharge for the 50 -year period of record is 7,960 $\mathrm{ft}^{3} / \mathrm{s}$ (fig. 4). The minimum annual mean discharge for the period of record $(1966-2015)$ is $1,710 \mathrm{ft}^{3} / \mathrm{s}$ in 2011 , followed by $2,240 \mathrm{ft}^{3} / \mathrm{s}$ in 2014. The maximum annual mean discharge is $22,400 \mathrm{ft}^{3} / \mathrm{s}$ in 2015. This study from May 2014 through December 2015 incorporates hydrologic data from periods of extreme low and high streamflow on the lower Trinity River. The dataset for this study includes observations from 2014 and 2015, the year with the second lowest annual discharge and the year with the maximum annual mean discharge, respectively. The large variation in annual mean discharge during the study was caused by below average precipitation in calendar year 2014 followed by above average annual precipitation in the upper Trinity River watershed in calendar year 2015 (National Oceanic and Atmospheric Administration National Centers for Environmental Information, 2016) resulting in the release of a large volume of water from Lake Livingston for extended periods. The water volume measured at the Goodrich site in 2015 accounted for 95 percent of the total volume measured at this site during the study period.

The streamflow patterns from May 2014 through December 2015 at the Goodrich, Romayor, and Liberty sites were similar (fig. 5). Daily mean discharge ranged from 984 to $72,400 \mathrm{ft}^{3} / \mathrm{s}$ at the Goodrich site and from 945 to $71,800 \mathrm{ft}^{3} / \mathrm{s}$ at the Romayor site. Minimum discharge at the Liberty site could not be determined as the station only computes discharge greater than $10,000 \mathrm{ft}^{3} / \mathrm{s}$, when tides do not affect streamflow computations. The maximum discharge at the Liberty site was $76,200 \mathrm{ft}^{3} / \mathrm{s}$, an increase likely attributed to local overland runoff in the lower reaches of the river. However, the distance between Lake Livingston to Galveston Bay is relatively short (100 river miles), so increases in discharge in the lower Trinity River as a result of overland runoff are minor when compared to the volume of water released from Lake Livingston. The peak discharge at the Liberty site in March and May 2015 was approximately $5,000 \mathrm{ft}^{3} / \mathrm{s}$ higher than at the Goodrich and Romayor sites (fig. 5), indicating that only 5-10 percent of the total discharge may be a result of overland runoff.

At the Wallisville site, daily mean discharge ranged from $-669 \mathrm{ft}^{3} / \mathrm{s}$ (a reversal of flow caused by tidal influences) on August 17, 2014, to $24,440 \mathrm{ft}^{3} / \mathrm{s}$ on December 17, 2015. During events in which discharge exceeded approximately $14,000 \mathrm{ft}^{3} / \mathrm{s}$ at the Goodrich, Romayor, and Liberty sites, only part of the 


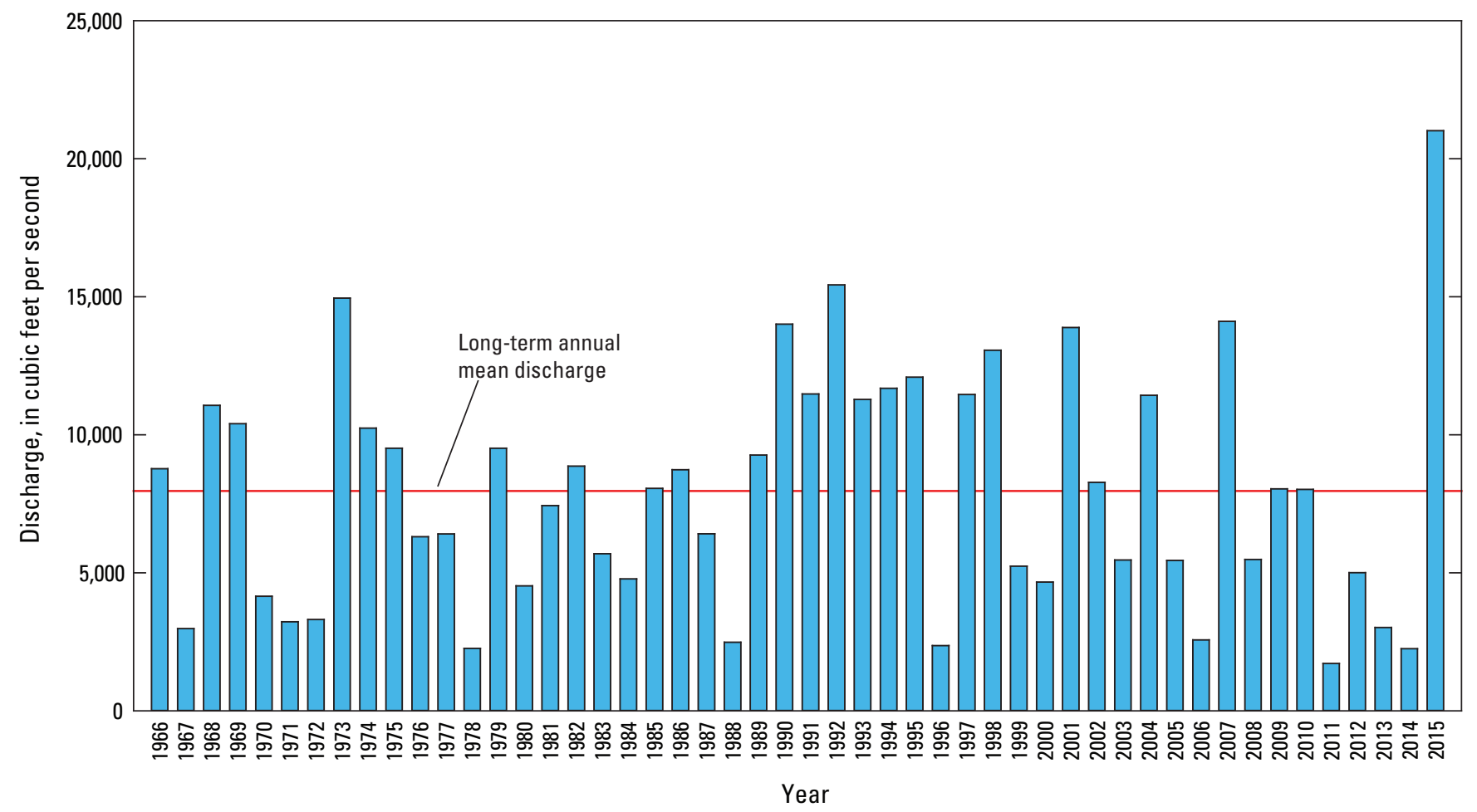

Figure 4. Annual daily mean discharge at U.S. Geological Survey streamflow-gaging station 08066250 Trinity River near Goodrich, Texas, 1966-2015.

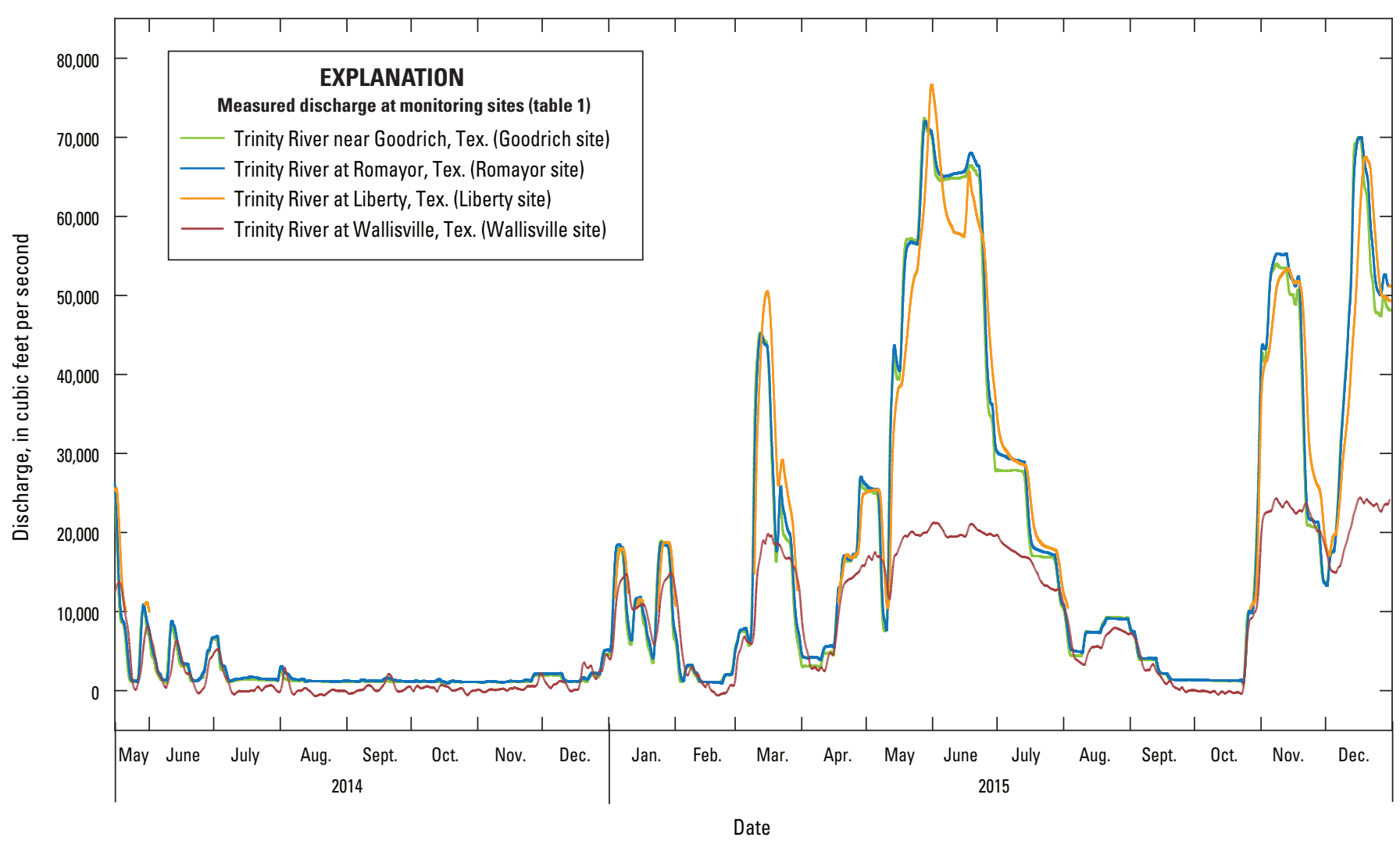

Figure 5. Instantaneous discharge at U.S. Geological Survey streamflow-gaging stations in the lower Trinity River watershed, Texas, May 2014-December 2015. 
volume was measured at the Wallisville site. For example, the peak discharge at the Liberty site during the high-flow event in December 2015 was 67,400 ft $\mathrm{ft}^{3} / \mathrm{s}$, whereas at the Wallisville site peak discharge was $24,440 \mathrm{ft}^{3} / \mathrm{s}$, accounting for only 36 percent of the streamflow measured upstream. The peak discharge at each site for seven high-flow events during the study period in which streamflow exceeded $14,000 \mathrm{ft}^{3} / \mathrm{s}$ and the percentage of the peak discharge measured at the Wallisville site as compared to the Liberty site, the closest upstream USGS streamflow-gaging station, are shown in table 3. The percentage of the peak discharge measured at the Wallisville site ranged from about 28 to 82 percent and decreased with event magnitude.

Differences between upstream stations and the Wallisville site were also observed in total volume computations for the study period. A total of 17,200,000 acre-feet (acre-ft) of water were measured at the Goodrich site, 17,700,000 acre-ft at the Romayor site, 15,400,000 acre-ft at the Liberty site, and 9,270,000 acre-ft at the Wallisville site. The water volume at the Liberty site is likely underestimated because of missing data from periods in which discharge was less than $10,000 \mathrm{ft}^{3} / \mathrm{s}$ and not reported (approximately 38 percent of the study period); however, because the majority of the water volume is transported during events exceeding this discharge, periods of missing data did not account for a large part of the total water volume.

Only about 54 percent of the total water volume released from Lake Livingston during May 2014-December 2015 (as measured at the Goodrich site) was accounted for at the Wallisville site. This difference in water volumes between upstream sites and the Wallisville site indicates that, at high flows, a large percentage of the volume released from Lake Livingston does not reach Galveston Bay through the main channel of the Trinity River. In addition, discharge at the Wallisville site increased and decreased at the same rate as upstream stations but at a lower magnitude; the main channel of the Trinity River at the Wallisville site only accommodated discharges of as much as approximately $24,000 \mathrm{ft}^{3} / \mathrm{s}$, even when discharges at upstream sites were approximately 2 to 4 times higher. These findings indicate that water likely flows into wetlands and water bodies surrounding the main channel of the Trinity River before reaching the Wallisville site and is being stored or discharged through other channels that flow directly into Galveston Bay.

\section{Suspended-Sediment Concentrations and Loads}

Suspended-sediment samples were collected at the Wallisville site at streamflow ranging from 238 to $22,700 \mathrm{ft}^{3} / \mathrm{s}$, accounting for approximately 72 percent of the range in streamflow for the period of record (May 2014-December 2015). A discharge-duration curve was prepared indicating the streamflow at which each sample was collected (fig. 6). This duration curve was developed using data collected during the 20-month period in which the streamflow-gaging station at the Wallisville site had been operating, the same period of this study. Because there were extended periods of both extreme low and high streamflow and a relatively short period of record for the Wallisville site, this duration curve may not be representative of long-term probability of exceedance; however, it is expected to be representative of the observed range of flows.

Table 3. Peak discharges measured at U.S. Geological Survey streamflow-gaging stations in the lower Trinity River watershed, Texas, May 2014-December 2015.

[ $\mathrm{ft}^{3} / \mathrm{s}$; cubic feet per second]

\begin{tabular}{ccccccc}
\hline $\begin{array}{c}\text { High-flow } \\
\text { event } \\
\text { number }\end{array}$ & Start date & \multicolumn{3}{c}{$\begin{array}{c}\text { Short name for sampling site (table 1) } \\
\text { Peak discharge (ft } \mathbf{s} \text { ) }\end{array}$} & $\begin{array}{c}\text { Percentage of peak } \\
\text { discharge measured at } \\
\text { Wallisville site }\end{array}$ \\
\cline { 3 - 6 } & & Goodrich & Romayor & Liberty & Wallisville & 81.7 \\
1 & $1 / 2 / 2015$ & 18,000 & 18,500 & 18,000 & 14,700 & 79.3 \\
3 & $1 / 22 / 2015$ & 18,800 & 18,700 & 18,800 & 14,900 & 39.2 \\
4 & $3 / 7 / 2015$ & 45,300 & 45,200 & 50,500 & 19,800 & 68.9 \\
5 & $4 / 12 / 2015$ & 26,400 & 26,800 & 25,400 & 17,500 & 27.8 \\
6 & $5 / 13 / 2015$ & 72,400 & 71,800 & 76,200 & 21,200 & 45.6 \\
7 & $10 / 24 / 2015$ & 54,000 & 55,300 & 53,300 & 24,300 & 36.2 \\
\hline
\end{tabular}




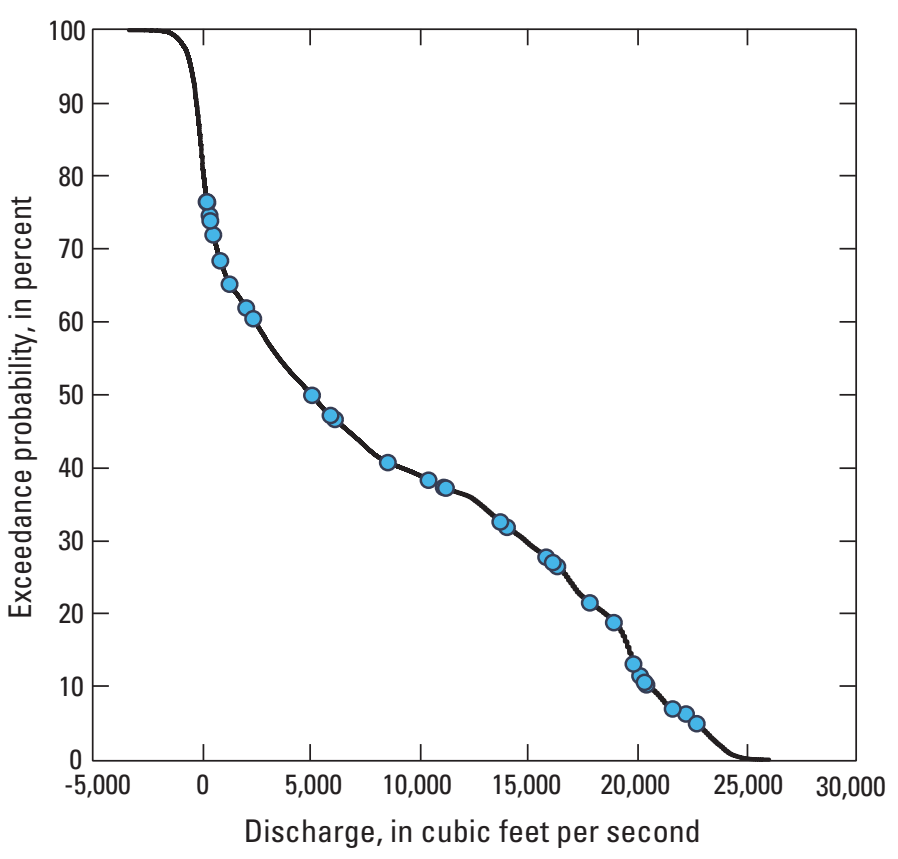

Figure 6. Discharge-duration curve indicating the streamflow at which each sample was collected at U.S. Geological Survey streamflow-gaging station 08067252 Trinity River at Wallisville, Texas, May 2014-December 2015.
Suspended-sediment concentrations measured in samples collected during May 2014-December 2015 ranged from 5 to $453 \mathrm{mg} / \mathrm{L}$, with a median of $65 \mathrm{mg} / \mathrm{L}$. Sand-fine separation analysis was done for 27 samples. In those samples, fine-sized suspended sediment represented 37 to 100 percent of all suspended-sediment particles, with the median composition consisting of 85.5 percent fine-sized particles and 14.5 percent sand-sized particles. The percentage of fine-sized particles decreased as discharged increased, indicating higher transport of sand-size particles at high flows (fig. 7).

A full particle-size distribution analysis was done for six samples collected between April 3, 2015, and June 10, 2015, mostly during high-flow events. In a suspended-sediment full particle-size distribution analysis, the percentages of material of each sediment size class (typically sand, silt, and clay) are determined (Guy, 1969). For the six samples analyzed for fullsize distribution during this study, the percentage of material smaller than $0.0625,0.125,0.250$, and $0.500 \mathrm{~mm}$ was determined. In these samples, all sediment particles were smaller than medium sand particles $(0.500 \mathrm{~mm})$. In addition, the percentage of sediment particles smaller than fine sand (smaller than $0.250 \mathrm{~mm}$ ) ranged from 96 to 100 percent (table 4), indicating that the majority of the suspended-sediment particles were silts, clays, and very fine and fine sand particles.

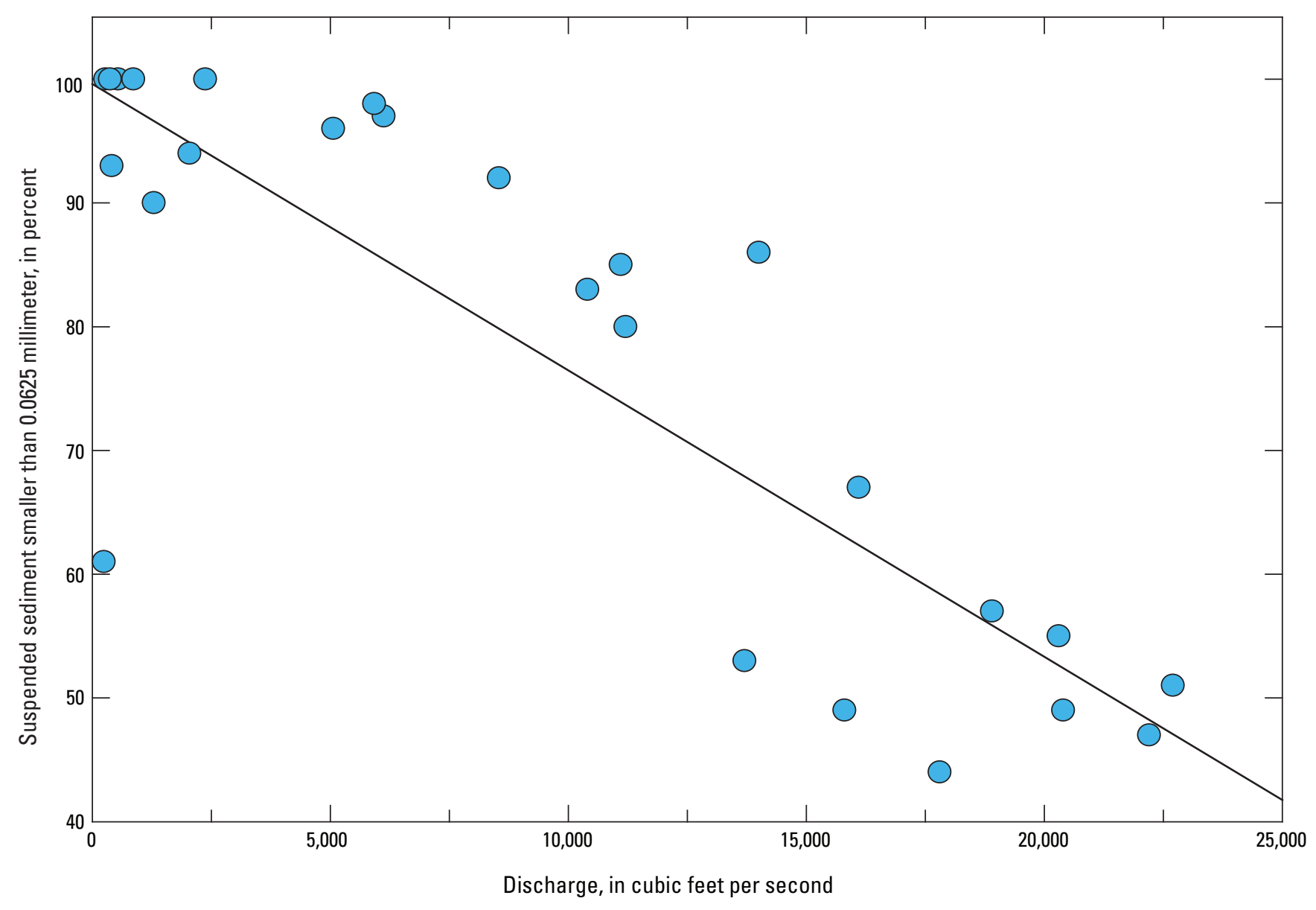

Figure 7. Graph showing relation between sand-fine separation results and discharge measured at U.S. Geological Survey streamflow-gaging station 08067252 Trinity River at Wallisville, Texas, May 2014-December 2015. 
Table 4. Results from suspended-sediment size analysis for selected samples in U.S. Geological Survey streamflow-gaging station 08067252 Trinity River at Wallisville, Texas, April 3, 2015-June 10, 2015.

[ft³ $/ \mathrm{s}$, cubic feet per second; mm, millimeters; -, no data]

\begin{tabular}{cccccc}
\hline Date & $\begin{array}{c}\text { Discharge } \\
(\mathbf{f t} \mathbf{3} / \mathbf{s})\end{array}$ & $\begin{array}{c}\text { Percent finer than } \\
\mathbf{0 . 0 6 2 5} \mathbf{~ m m ;} \\
\text { silt and clay }\end{array}$ & $\begin{array}{c}\text { Percent finer than } \\
\mathbf{0 . 1 2 5} \mathbf{~ m m ;} \\
\text { very fine sand }\end{array}$ & $\begin{array}{c}\text { Percent finer than } \\
\mathbf{0 . 2 5 0} \mathbf{~ m m ;} \\
\text { fine sand }\end{array}$ & $\begin{array}{c}\text { Percent finer than } \\
\mathbf{0 . 5 0 0} \mathbf{~ m m ;} \\
\text { medium sand }\end{array}$ \\
\hline 4/3/2015 & 5,060 & 96 & 99 & 100 & - \\
$5 / 4 / 2015$ & 15,800 & 49 & 70 & 98 & 100 \\
$5 / 18 / 2015$ & 18,900 & 57 & 79 & 98 & 100 \\
$5 / 22 / 2015$ & 20,400 & 49 & 76 & 98 & 100 \\
$5 / 30 / 2015$ & 22,200 & 47 & 66 & 98 & 100 \\
$6 / 10 / 2015$ & 21,600 & 37 & 46 & 96 & 100 \\
\hline
\end{tabular}

\section{Suspended-Sediment Acoustic Surrogate Model Results}

Simple and multiple linear regression models were evaluated to find the best predictor of suspended-sediment concentration. Discharge and $\overline{S C B}$ were used as predictive variables to develop different regression equations with the objective of identifying the regression equation that was the best predictor of suspended-sediment concentration. A log transformed regression model based on the combination of discharge and $\overline{S C B}$ showed the best relation to suspended-sediment concentration. The resultant suspended-sediment concentration equation for the selected model, after transformation to its original units, is:

$$
S S C=0.0269 \times 10^{0.0416 \overline{S C B}+0.000031 Q} \times 1.09,
$$

where

$$
\begin{array}{cl}
\text { SSC } & \begin{array}{c}
\text { is the suspended-sediment concentration, in } \\
\text { milligrams per liter; }
\end{array} \\
& \begin{array}{r}
\text { is the mean sediment corrected backscatter } \\
\text { (signal-to-noise ratio corrected for water }
\end{array} \\
& \text { and sediment attenuation); } \\
Q & \begin{array}{l}
\text { is discharge, in cubic feet per second; and } \\
\text { is Duan's bias correction factor (Duan, 1983). }
\end{array}
\end{array}
$$

The model in equation 4 was determined to be the best predictor of suspended-sediment concentration based on regression evaluation statistical measures. The model yielded an $\mathrm{R}^{2}$ of 0.92 and a RMSE of $1.65 \mathrm{mg} / \mathrm{L}$; the VIF for discharge and $\overline{S C B}$ is 2.41 , indicating little collinearity between variables (table 5 ). Residual and probability plots (fig. 8) indicate that the selected model resulted in residuals that met regression model assumptions of normality and constant variance. A model summary (app. 1) documenting calibration data and additional information on evaluation statistics of the acoustic surrogate model was created and reviewed as recommended by Landers and others (2016).

The relation between regression-estimated suspendedsediment concentrations and measured suspended-sediment concentrations is depicted on figure 9. The MAPE between estimated and measured suspended-sediment concentration was 35 percent. At suspended-sediment concentrations less than $350 \mathrm{mg} / \mathrm{L}$, the regression model generally overestimates suspended-sediment concentration. At suspended-sediment concentrations higher than $350 \mathrm{mg} / \mathrm{L}$, the regression model underestimates suspended-sediment concentration by an average of 48 percent. These patterns were also observed when evaluating other explanatory variables to estimate suspendedsediment concentrations; hence, the use of other explanatory variables was not a solution. A possible explanation for the underestimation at higher concentrations relates to the distribution of suspended sediment in the cross section at higher flows, when high suspended-sediment concentrations are typically observed. Backscatter contour plots from Acoustic Doppler current profiler (ADCP) measurements 
Table 5. Summary of linear regression evaluation statistics for equation using discharge and sediment corrected backscatter to estimate suspended-sediment concentration in U.S. Geological Survey streamflowgaging station 08067252 Trinity River at Wallisville, Texas, May 2014-December 2015.

[mg/L, milligrams per liter]

\begin{tabular}{lr}
\hline \multicolumn{2}{c}{ Model evaluation statistics } \\
\hline Number of observations & 31 \\
Root mean suqare error $(\mathrm{mg} / \mathrm{L})$ & 1.65 \\
Adjusted coefficient of determination $\left(\mathrm{R}_{\mathrm{a}}^{2}\right)$ & 0.92 \\
Nonparametric smearing bias correction factor & 1.09 \\
Variance inflation factor & 2.41 \\
\hline
\end{tabular}

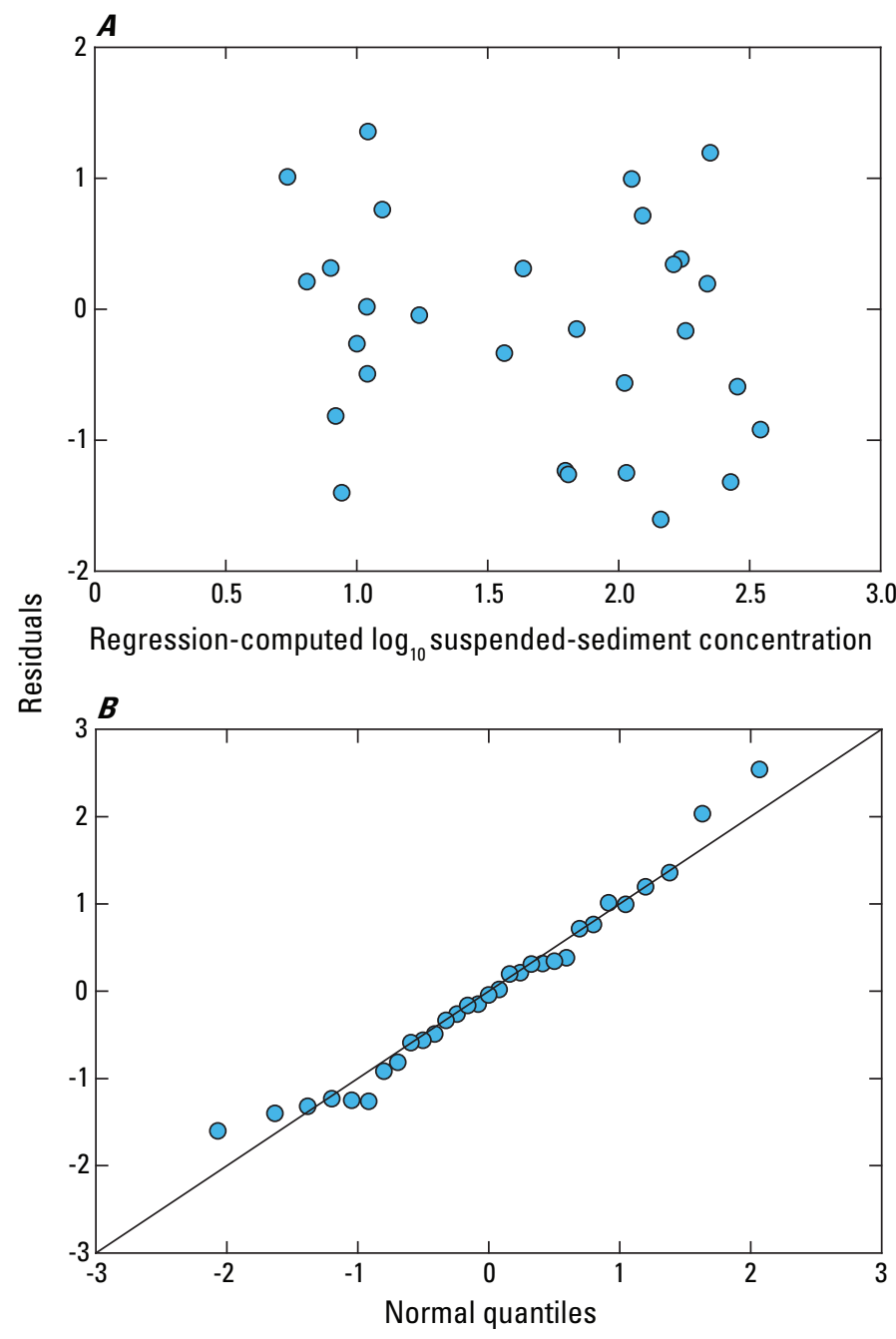

Figure 8. Estimated suspended-sediment concentrations for $A$, residual plot and $B$, normal probability plot for a multiple linear regression model developed for the Trinity River at U.S. Geological Survey streamflow-gaging station 08067252 Trinity River at Wallisville, Texas, May 2014December 2015.

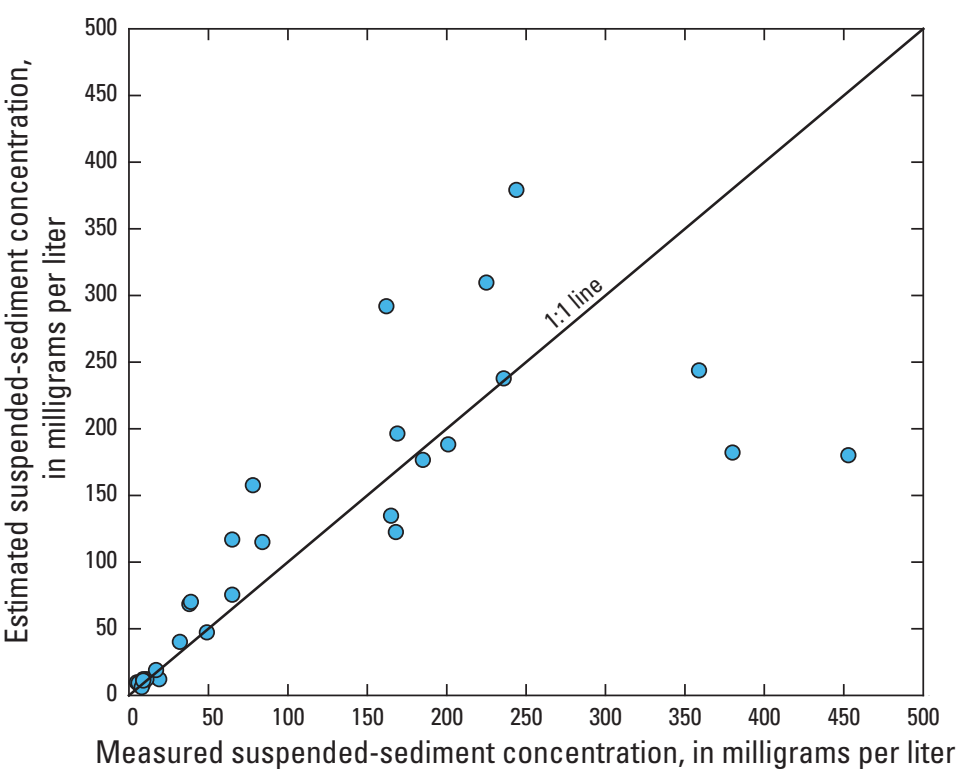

Figure 9. Estimated and measured suspended-sediment concentrations determined from a multiple linear regression model at U.S. Geological Survey streamflowgaging station 08067252 Trinity River at Wallisville, Texas.

(fig. 10) are shown to demonstrate the typical distribution of acoustic backscatter along the sampled cross section at various flow conditions. The backscatter profile is not homogeneous during high flows of more than approximately 6,000 $\mathrm{ft}^{3} / \mathrm{s}$, and the highest acoustic backscatter values typically are observed near the left bank and closer to the riverbed. In the example shown (fig. 10B), the highest backscatter values are measured approximately 200-260 ft from the ADVM, whereas the sample volume measured by the ADVM only extends approximately $60 \mathrm{ft}$. During high flows of approximately $6,000 \mathrm{ft}^{3} / \mathrm{s}$ or larger, suspended-sediment concentrations are estimated from acoustic backscatter data that are not representative of the entire cross section area. In order to represent the entire cross section area during these types of high-flow conditions, a lower frequency ADVM would have to be used; however, lower frequencies would not have the acoustic backscatter resolution to capture the fine-sized sediment particles typically found in the lower reaches of the Trinity River and may potentially underestimate suspended-sediment concentration over a larger range of suspended-sediment concentrations.

\section{Continuous Suspended-Sediment Concentrations}

Corrected acoustic backscatter and computed discharge data collected from May 16, 2014, through December 31, 2015 , were used as input in the regression model to estimate suspended-sediment concentrations at the Wallisville site at 15-minute intervals. Approximately 11 percent of the data used to estimate suspended-sediment concentration were outside the calibration range of the model; thus, these concentrations were extrapolated to obtain estimates of suspendedsediment concentrations for the entire study period. 


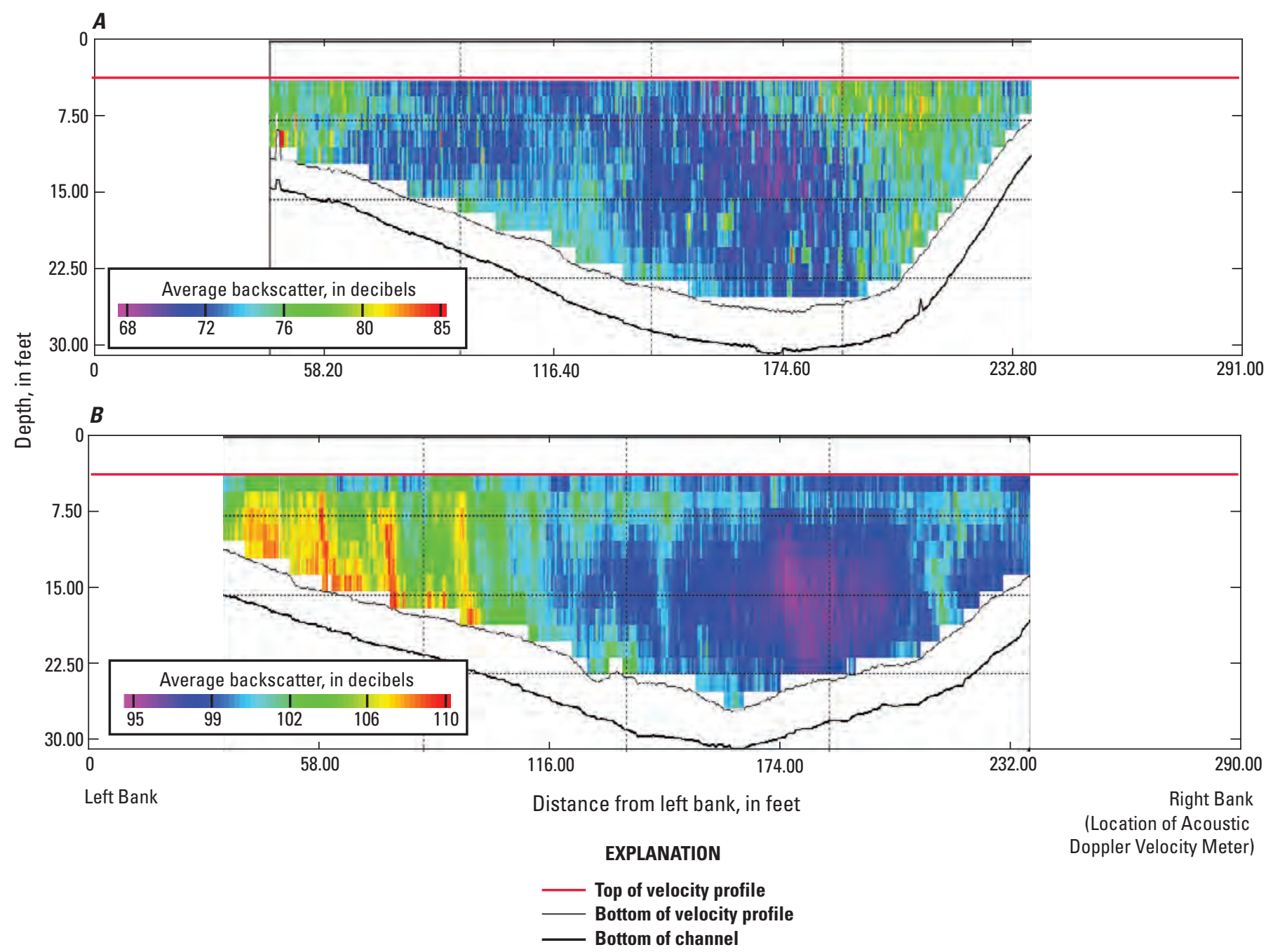

Figure 10. Example of acoustic backscatter profiles from Acoustic Doppler current profiler showing backscatter distributions in cross sections at discharges of $A, 2,370$ cubic feet per second ( $\left.\mathrm{ft}^{3} / \mathrm{s}\right)$, and $B, 13,700 \mathrm{ft}^{3} / \mathrm{s}$. The Acoustic Doppler velocity meter at U.S. Geological Survey streamflow-gaging station 08067252 Trinity River at Wallisville, Texas, is located on the right bank.

A 90-percent prediction interval was calculated for every observation to evaluate the uncertainty of regression-computed suspended-sediment concentrations. The 90-percent prediction interval represents a range of values within which there is a 90-percent certainty that the true suspended-sediment concentration value occurs (Rasmussen and others, 2009). The prediction interval for a single response $\left(y_{i}\right)$ is approximately

where

$$
E\left(y_{i}\right)+/-t \times s,
$$

$$
\begin{gathered}
E\left(y_{i}\right) \quad \begin{array}{l}
\text { is the regression-estimated value, at a single } \\
\text { set of values of the predictors; }
\end{array} \\
\text { is the value of the student's } t \text { distribution } \\
\text { having } \mathrm{n}-2 \text { degrees of freedom ( } \mathrm{n} \text { is } \\
\text { the number of observations) with the } \\
\text { exceedance probability of } \alpha / 2 \text { (alpha value }
\end{gathered}
$$

obtained from student's t distribution tables) for a 90 -percent prediction interval $\alpha=0.10$; and

$s \quad$ is the RMSE of the regression.

A time series of suspended-sediment concentration showing estimated suspended-sediment concentration and prediction intervals from January to December 2015 shows a similar pattern between suspended-sediment concentration and discharge (fig. 11). Suspended-sediment concentrations varied in response to changes in discharge, with peak suspendedsediment concentration occurring 1-2 days before the peak discharge for that event. Suspended-sediment concentrations also showed hysteresis, meaning that suspended-sediment concentrations on the rising limb of the hydrograph were higher than suspended-sediment concentrations at identical discharge on the falling limb. Because of the hysteresis in 


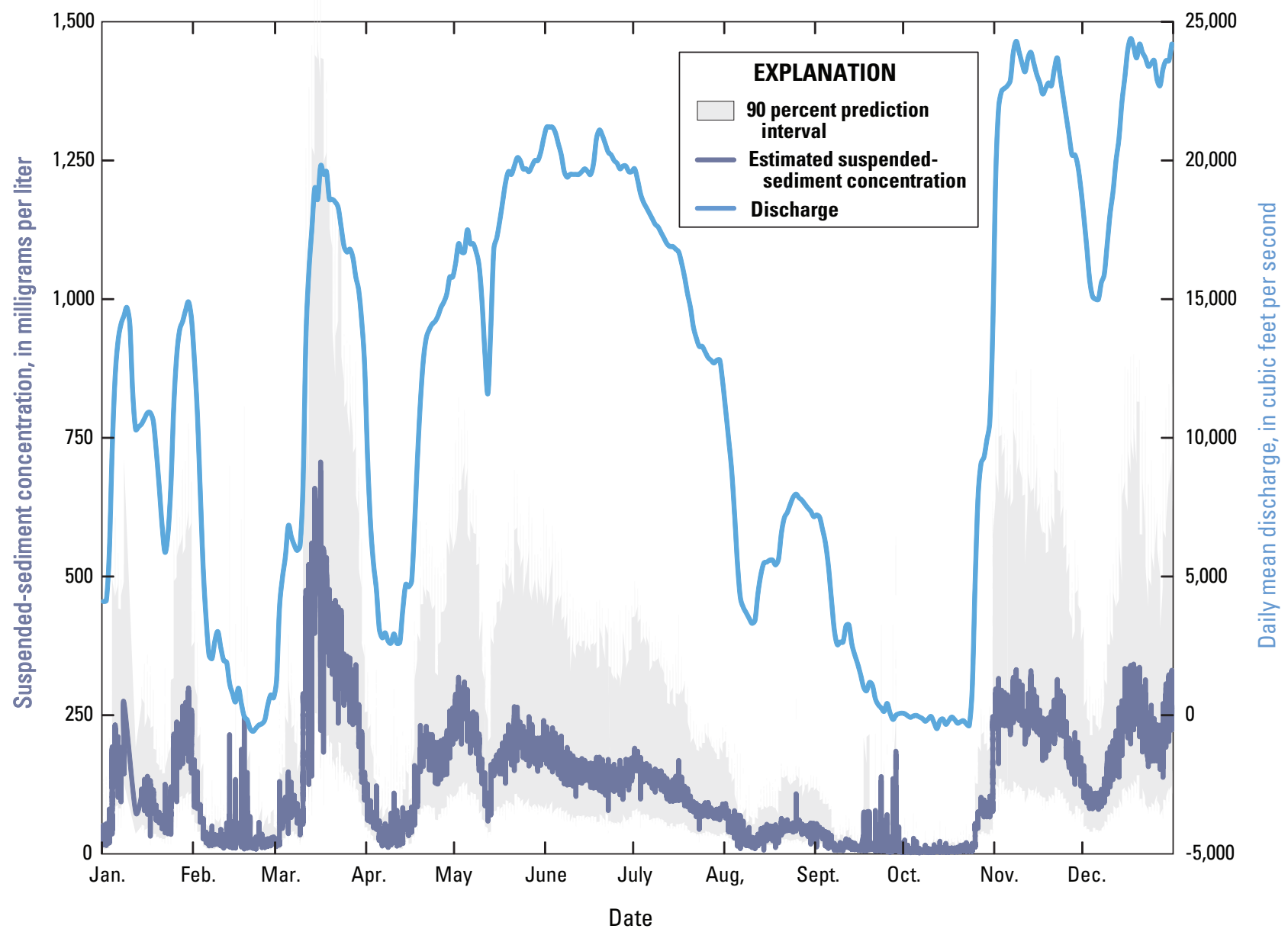

Figure 11. Suspended-sediment concentrations estimated by using a regression model developed for the Trinity River at U.S. Geological Survey streamflow-gaging station 08067252 Trinity River at Wallisville, Texas, January-December 2015.

suspended-sediment concentrations, discharge as the single predictor of suspended-sediment concentration would have overestimated values on the falling limb of the hydrograph.

During this study, estimated suspended-sediment concentration ranged from 2 to $701 \mathrm{mg} / \mathrm{L}$, with a mean of $97 \mathrm{mg} / \mathrm{L}$. The highest suspended-sediment concentrations were observed during the March 2015 event, which is the first event during this study with a large peak discharge similar in magnitude to the maximum discharge measured during the study period at the Wallisville site.

\section{Suspended-Sediment Loads}

Suspended-sediment loads (SSL) were computed from the suspended-sediment concentrations estimated by the regression equation and the corresponding streamflow. Instantaneous sediment load was computed by using the following equation:

$$
S S L_{i}=S S C_{i} \times Q \times c,
$$

where

$$
\begin{gathered}
S S L_{i} \quad \text { is the computed instantaneous suspended- } \\
\text { sediment load, in tons per } 15 \text { minutes, } \\
S S C_{i} \quad \text { is the computed instantaneous suspended- } \\
\text { sediment concentration, in milligrams } \\
\text { per liter, } \\
Q \quad \text { is the streamflow for the } i \text { th value, in cubic } \\
\text { feet per second, and } \\
\text { c is a constant, } 0.000028, \text { to convert the units to } \\
\text { tons per } 15 \text { minutes (Porterfield, 1972). }
\end{gathered}
$$

The resulting 15-minute estimates for a day were summed to determine the total daily SSL. The monthly SSL was computed by summing each daily SSL for that month. Because the estimated suspended-sediment concentrations computed from the regression equation contained error components as indicated by the RMSE and MAPE calculations between estimated and measured concentrations, the computed load estimates are inferred to also include errors. 


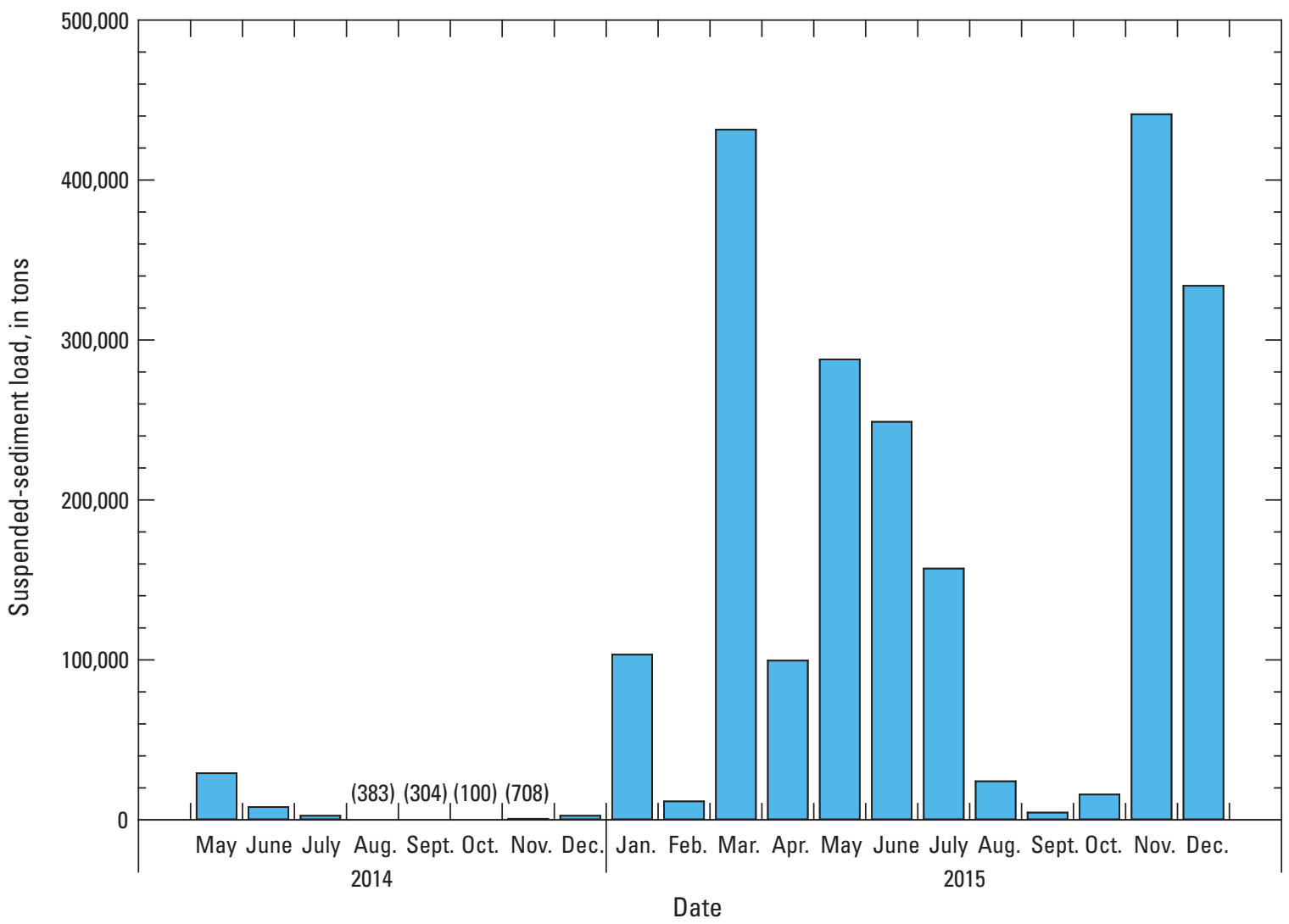

Figure 12. Estimated monthly suspended-sediment loads at U.S. Geological Survey streamflowgaging station 08067252 Trinity River at Wallisville, Texas, May 2014-December 2015.

The estimated minimum monthly SSL was 100 tons in October 2014, and the maximum monthly load was 441,000 tons in November 2015 (fig. 12). The total SSL at the Wallisville site during the study was approximately 2,200,000 tons, with approximately 96 percent of this load measured during the seven high-flow events in 2015 (table 6). High-flow event 5 contributed the largest SSL, approximately 27 percent of the

Table 6. Suspended-sediment load during high-flow events at U.S. Geological Survey streamflow-gaging station 08067252, Trinity River at Wallisville, Texas, May 2014-December 2015.

\begin{tabular}{cccc}
\hline $\begin{array}{c}\text { High-flow } \\
\text { event } \\
\text { number }\end{array}$ & Start date & End date & $\begin{array}{c}\text { Suspended- } \\
\text { sediment load } \\
\text { (tons) }\end{array}$ \\
\hline 1 & $1 / 2 / 2105$ & $1 / 12 / 2015$ & 26,176 \\
2 & $1 / 22 / 2015$ & $2 / 3 / 2015$ & 67,887 \\
3 & $3 / 7 / 2015$ & $4 / 6 / 2015$ & 430,959 \\
4 & $4 / 12 / 2015$ & $5 / 12 / 2015$ & 200,445 \\
5 & $5 / 13 / 2015$ & $8 / 9 / 2015$ & 593,764 \\
6 & $10 / 24 / 2015$ & $12 / 4 / 2015$ & 475,563 \\
7 & $12 / 5 / 2015$ & $12 / 31 / 2015$ & 315,289 \\
\hline
\end{tabular}

total load measured (table 6). This event started in May 2015 and ended in August 2015, making it the longest duration high-flow event during this study.

The water volume measured at the Wallisville site during high-flow events is a percentage of the volume measured at the Goodrich, Romayor, and Liberty sites; thus, the total SSL measured in the main channel of the Trinity River is considered to be a part of the total SSL transported from the Trinity River watershed into Galveston Bay. The remaining volume and SSL are believed to be diverted into adjacent wetlands and channels in the delta, which may be most of the SSLs during some high-flow events. The effect of these wetlands, in particular the Old River system, on the delivery of suspended sediment into Galveston Bay is not well understood; a decrease in water velocity caused by increasing vegetation and channel area could promote deposition of suspended-sediment particles, altering the quantity of SSLs and size distribution of suspended-sediment particles, and an unknown amount of the diverted SSL could be transported to Galveston Bay. Further study is needed to determine if the SSLs decrease and if the size distribution of suspended-sediment particles shifts as the Trinity River traverses the wetlands of the Old River System before emptying into Galveston Bay. 


\section{Characterization of Water-Quality Conditions}

Water-quality samples and field properties were collected at the Wallisville site concurrently with suspended-sediment samples over the range of flows shown in figure 6. Field properties include dissolved oxygen concentration, $\mathrm{pH}$, specific conductance, water temperature, and turbidity that were measured onsite during each sampling event of this study. Summary statistics for field properties at the Wallisville site are provided (table 7).

\section{Field Properties}

Dissolved oxygen concentration ranged from 4.3 to $13.4 \mathrm{mg} / \mathrm{L}$ and followed a seasonal pattern of higher concentrations during winter and spring and lower concentrations during summer and fall. Measured $\mathrm{pH}$ ranged from 7.1 to 8.2 and generally decreased when discharge was higher. Similar to $\mathrm{pH}$, specific conductance also decreased during higher flows, which is to be expected in watersheds where increased runoff dilutes the concentrations of ions. Specific conductance ranged from 276 microsiemens per centimeter at 25 degrees Celsius $\left(\mu \mathrm{S} / \mathrm{cm}\right.$ at $25^{\circ} \mathrm{C}$ ) to $433 \mu \mathrm{S} / \mathrm{cm}$ at $25^{\circ} \mathrm{C}$, a considerably low range for a site affected by tides (Miller, 1962); however, a lock and dam saltwater barrier operated by the U.S. Army Corp of Engineers approximately 2 river miles downstream from the Wallisville site prevents saltwater from entering the Trinity River by opening and closing gates, depending on tides and river flows. Turbidity ranged from 2.7 to 133 Formazin Nephelometric Units and increased with discharge, which is typical when larger amounts of suspended sediment are being transported during higher flows (table 7).

\section{Nutrients}

Water-quality samples were analyzed for ammonia, nitrate plus nitrite, nitrite, total nitrogen, orthophosphate, and total phosphorus. Summary statistics for nutrient samples collected at the Wallisville site are shown in table 8. As explained in the "Analytical Methods" section of this report, concentrations of total nitrogen are considered estimates because of potential method bias..

Concentrations of total nitrogen and total phosphorus in samples collected at the Wallisville site during May 2014December 2015 were plotted as separate time series (figs. $13 \mathrm{~A}$ and $13 B$ ) to evaluate variability of nutrient concentrations resulting from seasonality and changes in discharge (fig. 13C). Total nitrogen and total phosphorus concentrations fluctuated in a similar manner. During periods of low flow during JuneDecember 2014 (fig. 13C), when tidal influences controlled discharge in the lower Trinity River, the mean total nitrogen concentrations and total phosphorus concentrations were 0.66 and $0.092 \mathrm{mg} / \mathrm{L}$, respectively. A small peak in total nitrogen and total phosphorus concentrations is observed during September-October 2014 (figs. $13 A$ and 13B), possibly the result of localized runoff and agricultural activities (fall fertilization of crops, rice field flooding).

Table 7. Summary statistics for water-quality field properties measured at U.S. Geological Survey streamflow-gaging station 08067252 Trinity River at Wallisville, Texas, May 2014-December 2015.

$\left[\mathrm{mg} / \mathrm{L}\right.$, milligrams per liter; $\mu \mathrm{S} / \mathrm{cm}$ at $25^{\circ} \mathrm{C}$, microseimens per cetimeter at 25 degrees Celsius; ${ }^{\circ} \mathrm{C}$, degrees Celsius; FNU, Formazin Nephelometric Units]

\begin{tabular}{cccccc}
\hline & $\begin{array}{c}\text { Dissolved oxygen } \\
\text { concentration } \\
(\mathbf{m g} / \mathbf{L})\end{array}$ & $\begin{array}{c}\mathbf{p H} \\
\text { (standard } \\
\text { units) }\end{array}$ & $\begin{array}{c}\text { Specific con- } \\
\text { ductance }(\boldsymbol{\mu} \mathbf{S} / \\
\left.\mathbf{c m} \text { at } \mathbf{2 5} \mathbf{~}^{\circ} \mathbf{C}\right)\end{array}$ & $\begin{array}{c}\text { Water } \\
\text { temperature } \\
\left({ }^{\circ} \mathbf{C}\right)\end{array}$ & $\begin{array}{c}\text { Turbidity } \\
\text { (FNU) }\end{array}$ \\
\hline Maximum & 13.4 & 8.2 & 433 & 32.5 & 133 \\
Mimimum & 4.3 & 7.1 & 276 & 8.8 & 2.7 \\
Median & 7.5 & 7.6 & 364 & 22.3 & 28 \\
\hline
\end{tabular}

Table 8. Summary statistics for nutrient parameters measured in the Trinity River at Wallisville, Texas, May 2014-December 2015.

[mg/L, milligrams per liter; $\mathrm{N}$, nitrogen; $\mathrm{P}$, phosphorus; <, less than]

\begin{tabular}{ccccccc}
\hline & $\begin{array}{c}\text { Ammonia } \\
(\mathbf{m g} / \mathbf{L} \text { as } \mathbf{~})\end{array}$ & $\begin{array}{c}\text { Nitrate plus } \\
\text { nitrite } \\
(\mathbf{m g} / \mathbf{L} \text { as } \mathbf{~})\end{array}$ & $\begin{array}{c}\text { Nitrite } \\
(\mathbf{m g} / \mathbf{L} \text { as } \mathbf{~})\end{array}$ & $\begin{array}{c}\text { Total nitrogen } \\
(\mathbf{m g} / \mathbf{L})^{\mathbf{1}}\end{array}$ & $\begin{array}{c}\text { Orthophos- } \\
\text { phate } \\
\text { (mg/L as } \mathbf{P})\end{array}$ & $\begin{array}{c}\text { Total } \\
\text { phosphorus }\end{array}$ \\
\hline Maximum & 0.08 & 0.779 & 0.030 & 1.64 & 0.100 & 0.274 \\
Mimimum & $<0.01$ & $<0.040$ & $<0.001$ & 0.56 & 0.006 & 0.067 \\
Median & 0.02 & 0.195 & 0.006 & 0.93 & 0.037 & 0.120 \\
\hline
\end{tabular}

${ }^{1}$ Concentrations of total nitrogent are considered estimates because of potential method bias (Rus and others, 2013). 

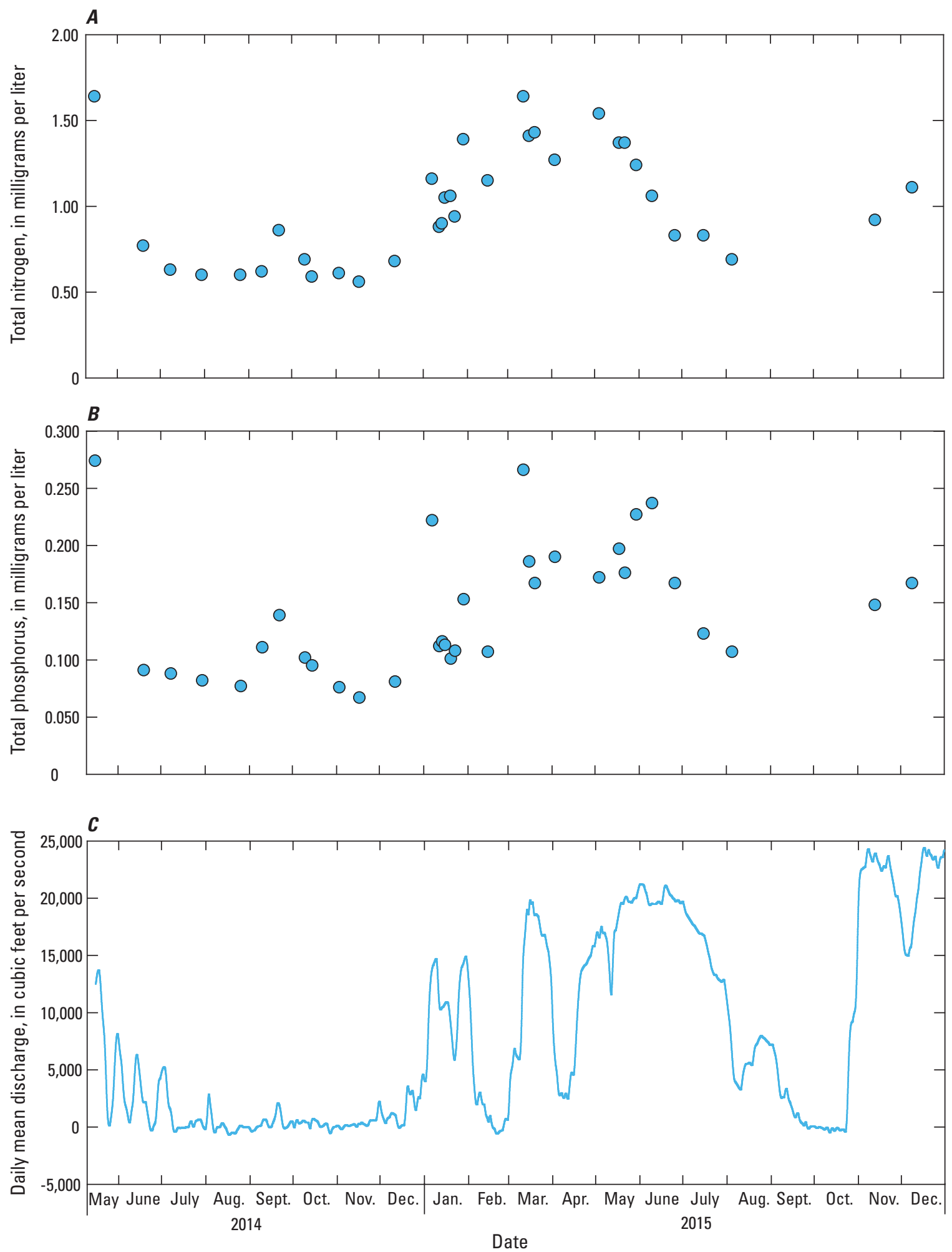

Figure 13. Time series depicting concentrations of $A$, total nitrogen; $B$, total phosphorus; and $C$, associated daily mean discharge for samples collected at U.S. Geological Survey streamflow-gaging station 08067252 Trinity River at Wallisville, Texas, May 2014-December 2015. 
The highest nutrient concentrations are observed during periods of high flow corresponding to releases from Lake Livingston. For samples collected during the seven high-flow events in 2015 (table 3), when releases from Lake Livingston composed most of the discharge in the lower Trinity River, mean total nitrogen and total phosphorus concentrations were $1.15 \mathrm{mg} / \mathrm{L}$ and $0.165 \mathrm{mg} / \mathrm{L}$, respectively, which are approximately 75 percent higher than the mean concentrations measured during periods of low flow. Increases in nutrient concentrations with flow may be caused by (1) transportation of water with high nutrient concentrations from Lake Livingston and the upper Trinity River watershed and (2) mobilization of nutrients stored in the lower Trinity River channel and flood plain during periods of high flow. The small contribution of overland runoff to stream discharge indicates overland runoff within the lower Trinity River watershed is not responsible for increases observed in nutrient concentrations. The high concentrations of nutrients delivered to the Wallisville site because of increased discharge from these releases also overshadow the influence of seasonal effects in nutrient variability at the Wallisville site; as a result, nutrient delivery to Galveston Bay from the main channel of the Trinity River likely is controlled primarily by high-flow releases from Lake Livingston.

To determine the effect of streamflow variability on the relative amounts of ammonia, nitrate, nitrite, and organic nitrogen at the Wallisville site, the percentage of the composition of each form of nitrogen was computed for each sample. Censored values for ammonia, nitrate, and nitrite were substituted by using one-half the method reporting limit (Helsel and Hirsch, 2002). Maximum likelihood and robust methods are recommended over simple substitution for censored values (Helsel and Hirsch, 2002; Helsel, 2012); however, the chosen substitution method was used because censored results represent a relatively small percentage (less than 1 percent for ammonia and nitrite and less than 5 percent for nitrate) of the total nitrogen in each sample and do not appreciably affect the overall proportion of each form of nitrogen.

For most samples collected at the Wallisville site, organic nitrogen was the predominant form of nitrogen, ranging from approximately 44 to 96 percent (fig. 14). Land cover in the lower Trinity River watershed is predominantly forest and wetlands, indicating that natural inputs are likely the main source of organic nitrogen (and total nitrogen) during low-flow conditions. When discharge increases as a result of releases from Lake Livingston, the concentration of organic nitrogen typically decreased and the concentration of nitrate increased. This shift in nitrogen composition may be the result of a change in the source of nitrogen inputs to the lower Trinity River, from natural inputs derived from wetlands and forested areas to nitrogen from fertilizers carried in runoff in the upper Trinity River watershed. Releases from Lake Livingston are typically triggered by rainfall in the upper Trinity River watershed, where approximately half of the land cover is categorized as developed or agricultural (Homer and others, 2015). Runoff in the upper Trinity River watershed likely carries nitrate from fertilizers that flow into Lake Livingston and are transported into the lower Trinity River watershed during releases. Because organic nitrogen and nitrate are the predominant forms of nitrogen in the Trinity River, the proportion of ammonia and nitrite was low, ranging from 0.4 to 9 percent and 0.1 to 5 percent, respectively.

Releases from Lake Livingston also appear to influence the composition of phosphorus being transported in the lower Trinity River. Dissolved phosphorus (predominantly orthophosphate) interacts with sediment particles through adsorption, often causing a proportional increase in particulate phosphorus concentrations with increasing suspended-sediment concentrations (Sharpley and others, 1981, House and others, 1998). This pattern is observed at the Wallisville site (fig. 15), potentially as a result of sediment suspended within releases of water from Lake Livingston and mobilization during periods of high flow of previously deposited sediment particles from the river channel and flood plain (Dorioz, 1995; Withers and Jarvie, 2008). Orthophosphate concentrations do not appear to vary considerably with suspended-sediment concentrations or discharge; however, the difference between orthophosphate concentrations and total phosphorous concentrations increased as suspended-sediment concentrations increased, indicating that the variability of phosphorus concentrations is a result of an increase in particulate phosphorus and not of orthophosphate. Consequently, the predominant source of phosphorous to Galveston Bay from the Trinity River was in particulate form tied closely to suspended-sediment concentrations.

The changes in nutrient concentration and composition during this study, caused by high flow from Lake Livingston releases, indicate that the reservoir likely plays an important role in the delivery of nutrients into Galveston Bay. However, the role of Lake Livingston in the transforming and trapping of nutrients and sediment and the extent of nutrient and sediment mobilization in the lower Trinity River, triggered by releases, are not well understood. Further study is needed to better understand the processes driven by Lake Livingston that could be influencing the characteristics of nutrients and sediments in inflows to Galveston Bay. Additionally, because phosphorous concentrations were correlated with suspended-sediment concentrations ( $\mathrm{R}^{2}$ value of 0.75$)$ and because the relative amounts of phosphorous and some nitrogen forms (organic nitrogen and nitrate) varied with discharge, the diversion of water and suspended sediment into surrounding wetlands and channels outside of the main channel of the Trinity River may play a large role in the regulation of nutrient inputs into Galveston Bay. 


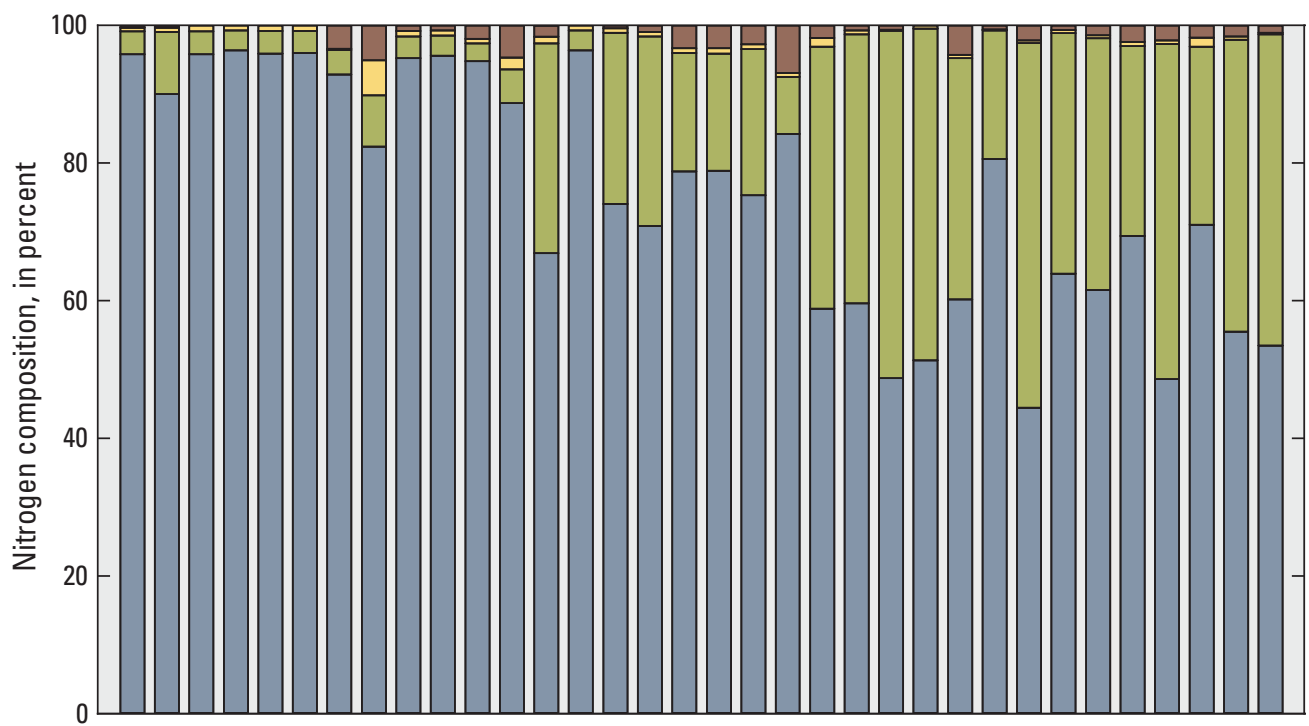

EXPLANATION

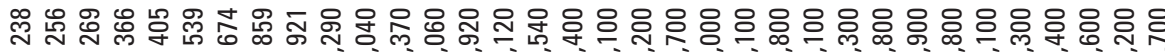

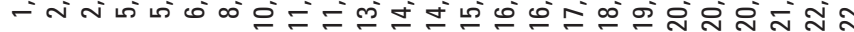

Measured discharge, in cubic feet per second

Figure 14. Percentages of nitrogen constituents in water-quality samples collected at U.S. Geological Survey streamflow-gaging station 08067252 Trinity River at Wallisville, Texas, May 2014-December 2015.

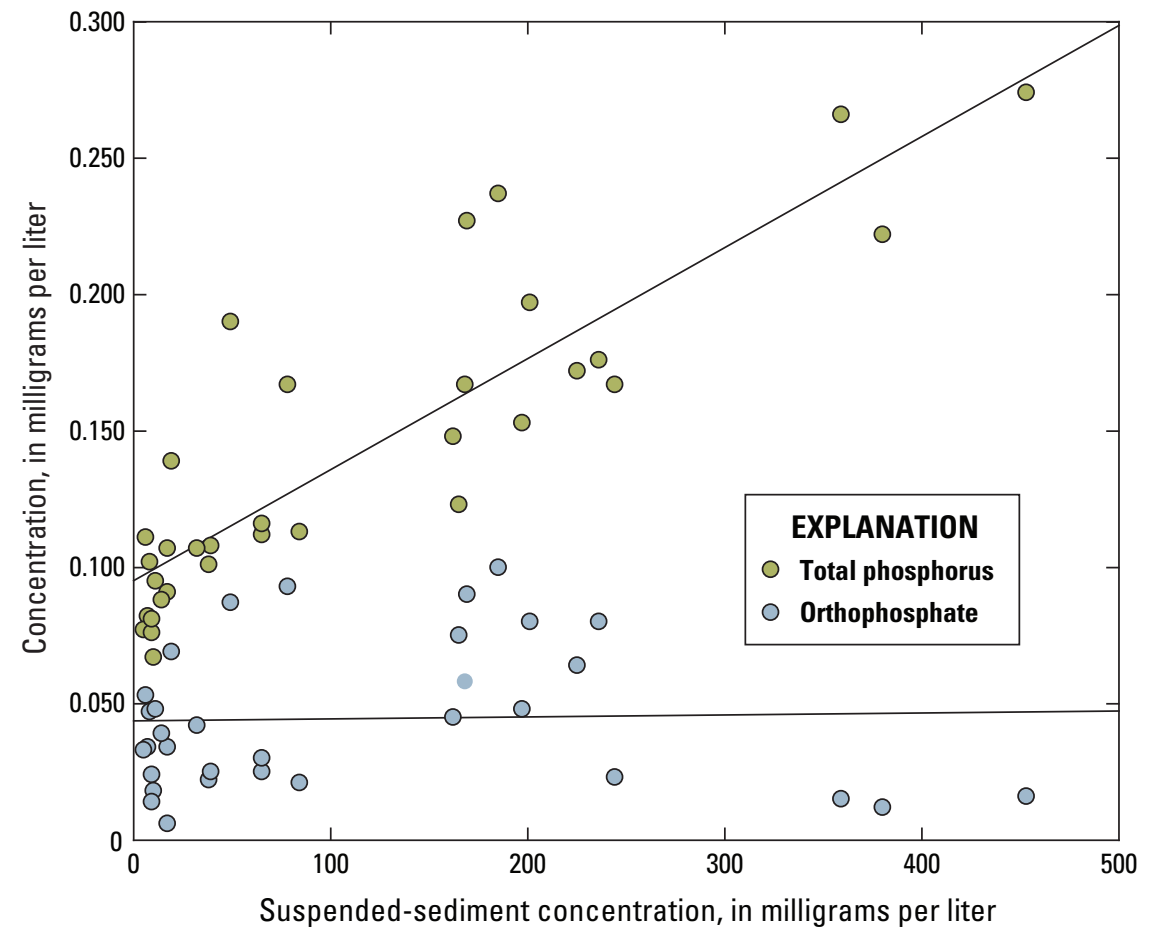

Figure 15. Relation between phosphorus concentrations and suspendedsediment concentrations at U.S. Geological Survey streamflow-gaging station 08067252 Trinity River at Wallisville, Texas, May 2014-December 2015. 


\section{Summary}

The U.S. Geological Survey (USGS), in cooperation with the Texas Water Development Board and the Galveston Bay Estuary Program, collected streamflow and water-quality data at USGS streamflow-gaging stations in the lower Trinity River watershed from May 2014 to December 2015 to characterize and improve the current understanding of the quantity and quality of freshwater inflows entering Galveston Bay from the Trinity River. Continuous streamflow records at four USGS streamflow-gaging stations were compared to assess changes in streamflow magnitude and to quantify discrepancies in streamflow between upstream and downstream reaches of the Trinity River separated by Lake Livingston, and waterquality conditions were characterized from discrete nutrient and sediment samples collected over a range of hydrologic conditions at USGS streamflow-gaging station 08067252 Trinity River at Wallisville, Tex. (hereinafter referred to as "the Wallisville site").

During May 2014-December 2015, 08066250 Trinity River near Goodrich, Tex. (hereinafter referred to as "the Goodrich site"), 08066500 Trinity River at Romayor, Tex. (hereinafter referred to as "the Romayor site"), 08067000 Trinity River at Liberty, Tex. (hereinafter referred to as "the Liberty site"), and at the Wallisville site followed a similar streamflow pattern in which computed discharge was of comparable magnitude; however, during events in which discharge exceeded approximately 14,000 cubic feet per second at the Goodrich, Romayor, and Liberty sites, only part of the volume was measured at the Wallisville site. During this study, only about 54 percent of the total volume released from Lake Livingston was accounted for at the Wallisville site. Additionally, discharge at the Wallisville site increased and decreased at the same rate as upstream stations but at a lower magnitude. This difference in water volume and discharge between upstream sites and the Wallisville site indicates that, at high flows, a large part of the volume released from Lake Livingston did not reach Galveston Bay through the main channel of the Trinity River. It is likely that water flowed into wetlands and water bodies surrounding the main channel of the Trinity River before reaching the Wallisville site and was stored or discharged through channels in the Old River system that flow directly into Galveston Bay.

To characterize suspended-sediment concentrations and loads in Trinity River inflows to Galveston Bay, a regression model was developed to estimate suspended-sediment concentrations using acoustic data as a surrogate. The selected regression was based on the combination of water and sediment corrected backscatter and discharge. Suspended-sediment concentrations varied in response to changes in discharge, where peak suspended-sediment concentrations occurred 1 to 2 days before the peak discharge for that event. Suspendedsediment concentrations also showed hysteresis, meaning that suspended-sediment concentrations on the rising limb of the hydrograph were higher than suspended-sediment concentrations at identical discharge on the falling limb.
Because the water volume measured at the Wallisville site during high-flow events is a percentage of the volume measured at the Goodrich, Romayor, and Liberty sites, the total suspended-sediment load measured at the Wallisville site was considered to be a percentage of the total suspendedsediment load transported from the Trinity River watershed into Galveston Bay. The remaining volume and suspendedsediment load may be diverted into adjacent wetlands and channels in the delta, which may be the majority of the suspended-sediment loads during some high-flow events, and an unknown amount of this diverted load could be transported to Galveston Bay.

Results from nutrient samples collected at the Wallisville site indicated that total nitrogen and total phosphorus concentrations fluctuated at a similar rate, with the highest nutrient concentrations occurring during periods of high flows corresponding to releases from Lake Livingston. The mean concentrations of total nitrogen and total phosphorus were approximately 75 percent higher during high flow releases than during periods of low flow, overshadowing the influence of seasonal effects in nutrient variability at the Wallisville site; as a result, nutrient delivery to Galveston Bay from the main channel of the Trinity River likely is controlled primarily by high flow releases from Lake Livingston from transportation of water with high nutrient concentrations from Lake Livingston and the upper Trinity River watershed and mobilization of nutrients stored in the lower Trinity River channel and flood plain.

Increases in streamflow also appeared to influence the composition of nitrogen and phosphorus constituents. For most samples collected at the Wallisville site, organic nitrogen was the predominant form of nitrogen; however, when discharge increased because of releases from Lake Livingston, the percentage of organic nitrogen typically decreased and the percentage of nitrate increased. This shift in nitrogen composition was attributed to a change in the source of nitrogen, from natural inputs derived from wetlands and forested areas to nitrogen from fertilizers carried in runoff from the upper Trinity River watershed. The concentrations of total phosphorus also increased during high-flow events, likely because of suspended-sediment concentrations within Lake Livingston releases and mobilization of sediment particles in the river channel and flood plain during these periods of high flow. The increase of total phosphorous concentrations with suspendedsediment concentrations, while orthophosphate concentrations remained constant, indicated that the variability of phosphorus concentrations was a result of an increase in particulate phosphorus. Consequently, the predominant source of phosphorous to Galveston Bay from the Trinity River was in particulate form tied closely to suspended-sediment concentrations.

The changes in nutrient concentration and composition caused by releases from Lake Livingston during this study indicated that the reservoir plays an important role in the delivery of nutrients into Galveston Bay, but further study is needed to better understand the processes in Lake Livingston that influence the characteristics of nutrients and sediments in inflows to Galveston Bay. Because phosphorous 
concentrations were correlated with suspended-sediment concentrations (coefficient of determination $\left[\mathrm{R}^{2}\right]$ value of 0.75 ) and because the relative amounts of nutrients responded to changes in discharge, the diversion of water and suspended sediment into surrounding wetlands and channels outside of the main channel of the Trinity River may play a large role in the regulation of nutrient inputs into Galveston Bay.

\section{References Cited}

Alexander, R.B., Smith, R.A., and Schwarz, G.E., 2000, Effect of stream channel size on the delivery of nitrogen to the Gulf of Mexico: Nature, v. 403, p. 758-761.

Belsley, D.A., Kuh, Edwin, and Welsch, R.E., 1980, Regression diagnostics - Identifying influential data and sources of collinearity: New York, Wiley, 300 p. [Available online at http://onlinelibrary.wiley.com/book/10.1002/0471725153].

Bouwman, A.F., Van Drecht, G., Knoop, J.M., Beusen, A.H.W., and Meinardi, C.R., 2005, Exploring changes in river nitrogen export to the world's oceans: Global Biogeochemical Cycles, v. 19, no. 1, accessed November 28, 2016, at http:// onlinelibrary.wiley.com/doi/10.1029/2004GB002314/epdf.

Bricker, S.B., Longstaff, B., Dennison, W., Jones, A., Boicourt, K., Wicks, C., and Woerner, J., 2008, Effects of nutrient enrichment in the nation's estuariesA decade of change: Harmful Algae, v. 8, no. 1, p. 21-32, accessed November 28, 2016, at http://dx.doi. org/10.1016/j.hal.2008.08.028.

Capel, P.D., and Larson, S.J., 1995, Evaluation of selected information on splitting devices for water samples: U.S. Geological Survey Water-Resources Investigations Report 95-4141, 103 p. [Also available at http://pubs.usgs.gov/ wri/1995/4141/report.pdf.]

Chai, T., and Draxler, R.R., 2014, Root mean square error (RMSE) or mean absolute error (MAE)?-Arguments against avoiding RMSE in the literature: Geoscience Model Development, v. 7, p. 1247-1250, accessed November 28, 2016, at http:/www.geosci-model-dev.net/7/1247/2014/.

Childress, C.J.O., Foreman, W.T., Connor, B.F., and Maloney, T.J., 1999, New reporting procedures based on longterm method detection levels and some considerations for interpretations of water-quality data provided by the U.S. Geological Survey National Water Quality Laboratory: U.S. Geological Survey Open-File Report 99-193, 19 p. [Also available online at http://water.usgs.gov/owq/ OFR_99-193/.]

Cloern, J.E., 1987, Turbidity as a control on phytoplankton biomass and productivity in estuaries: Continental Shelf Research, v. 7, p. 1367-1381.
Domanski, M.M., Straub, T.D., and Landers, M.N., 2015, Surrogate Analysis and Index Developer (SAID) tool (version 1.0, September 2015): U.S. Geological Survey Open-File Report 2015-1177, 38 p., accessed November 28, 2016, at http://pubs.usgs.gov/of/2015/1177/ofr20151177.pdf.

Dorioz, J.M., 1995, Phosphorus storage, transport and transformations in river systems of the Lake Leman basin, in Kronvang B., Svendsen L.M., Sibbesen E., eds., Phosphorus and sediment: Ministry of Environment and Energy International Workshop, Silkeborgm Denmark, October 9-12, 1995 [Proceedings], p. 81-88.

Duan, Naihua, 1983, Smearing estimate-A nonparametric retransformation method: Journal of the American Statistical Association, v. 78, no. 383, p. 605-610.

Edwards, T.K., and Glysson, G.D., 1999, Field methods for measurement of fluvial sediment: U.S Geological Survey Techniques of Water-Resource Investigations, book 3, chap. C2 (rev.), 89 p. [Also available at http://pubs.usgs. gov/twri/twri3-c2/.]

Fishman, M.J., ed., 1993, Methods of analysis by the U.S. Geological Survey National Water Quality LaboratoryDetermination of inorganic and organic constituents in water and fluvial sediments: U.S. Geological Survey OpenFile Report 93-125, 217 p. [Available online at http://pubs. usgs.gov/of/1993/0125/report.pdf.]

Galloway, J.N., Dentener, F.J., Capone, D.G., Boyer, E.W., Howarth, R.W., Seitzinger, S.P., Asner, G.P., Cleveland, C.C., Green, P.A., Holland, E.A., and Karl, D.M., 2004, Nitrogen cycles_-Past, present, and future: Biogeochemistry, v. 70, no. 2, p. 153-226.

Galveston Bay Estuary Program, 2016, The Bay's priority problems, accessed October 19, 2017, at http://www.gbep. state.tx.us/the-bays-priority-problems/.

Guy, H.P., 1969, Laboratory theory and methods for sediment analysis: U.S. Geological Survey Techniques of WaterResources Investigations, chap. $\mathrm{Cl}$, book 5, $58 \mathrm{p}$.

Hamilton, S.K., Tank, J.L., Raikow, D.F., Wollheim, W.M., Peterson, B.J., and Webster, J.R., 2001, Nitrogen uptake and transformation in a Midwestern U.S. stream-A stable isotope enrichment study: Biogeochemistry, v. 54, no. 3, p. 297-340, accessed November 28, 2016, at http://link. springer.com/article/10.1023/A:1010635524108.

Harding, L.W., Meeson, B.W., and Fisher, T. R., 1986, Phytoplankton production in two east coast estuariesPhotosynthesis-light functions and patterns of carbon assimilation in Chesapeake and Delaware bays: Estuarine, Coastal and Shelf Science, v. 23, no. 6, p. 773-806. [Also available at http:/www.sciencedirect.com/science/article/ pii/0272771486900740]. 
Helsel, D.R., 2012, Statistics for censored environmental data using Minitab and R (2d ed.): New York, John Wiley and Sons, 344 p. [Also available at http://www.wiley.com/ WileyCDA/WileyTitle/productCd-0470479884.html.]

Helsel, D.R., and Hirsch, R.M., 2002, Statistical methods in water resource: U.S. Geological Survey Techniques of Water-Resources Investigations, book 4, chap. A3, 510 p., accessed September 16, 2016, at https://pubs.usgs.gov/twri/ twri4a3/\#pdf.

Homer, C.G., Dewitz, J.A., Yang, L., Jin, S., Danielson, P., Xian, G., Coulston, J., Herold, N.D., Wickham, J.D., and Megown, K., 2015, Completion of the 2011 National Land Cover Database for the conterminous United StatesRepresenting a decade of land cover change information: Photogrammetric Engineering and Remote Sensing, v. 81, no. 5 , p. 345-354.

Horowitz, A.J., Hayes, T.S., Gray, J.R., and Capel, P.D., 1997, Selected laboratory tests of the whole-water sample splitting capabilities of the 14-liter churn and the Teflon cone splitters: U.S. Geological Survey Office of Water Quality Technical Memorandum No. 97.06, 28 p.

House, W.A., 2003, Geochemical cycling of phosphorus in rivers: Applied Geochemistry, v. 18, no. 5, p. 739-748.

House, W.A., Jickells, T.D., Edwards, A.C., Praska, K.E., and Denison, F.H., 1998, Reactions of phosphorus with sediments in fresh and marine waters: Soil Use and Management, v. 14, p. 139-146.

Kennish, M.J., 2002, Environmental threats and environmental future of estuaries: Environmental Conservation, v. 29, no. 1, p. $78-107$.

Kimmerer, W.J., 2002, Physical, biological, and management responses to variable freshwater flow into the San Francisco Estuary: Estuaries, v. 25, no. 6, p. 1275-1290, accessed October 13, 2016, at http://link.springer.com/ article/10.1007/BF02692224.

Landers, M.N., Straub, T.D., Wood, M.S., and Domanski, M.M., 2016, Sediment acoustic index method for computing continuous suspended-sediment concentrations: U.S. Geological Survey Techniques and Methods, book 3, chap. C5, 63 p., accessed October 3, 2016, at http://dx.doi. org $/ 10.3133 / \mathrm{tm} 3 \mathrm{C} 5$.

Lee, M.T., 2010, A preliminary evaluation of Trinity River sediment and nutrient loads into Galveston Bay, Texas, during two periods of high flow, in Second Joint Federal Interagency Conference, Las Vegas, Nevada, June 27-July 1, 2010, Proceedings: Ninth Federal Interagency Sedimentation Conference and Fourth Federal Interagency Hydrologic Modeling Conference, $12 \mathrm{p}$.
Lee, W., Buzan, D., Eldridge, P., and Pulich, W., 2001, Freshwater inflow recommendation for the TrinitySan Jacinto Estuary of Texas: Austin, Tex., Texas Parks and Wildlife, $59 \mathrm{p}$.

Lester, L.J., and Gonzalez, L.A., eds., 2011, The state of the bay-A characterization of the Galveston Bay ecosystem (3d ed.): Houston, Tex., Texas Commission on Environmental Quality, Galveston Bay Estuary Program, 356 p., accessed November 28, 2016, at http://galvbaydata.org/ StateoftheBay/tabid/1846/Default.aspx.

Levesque, V.A., and Oberg, K.A., 2012, Computing discharge using the index velocity method: U.S. Geological Survey Techniques and Methods, book 3, chap. A23, 148 p., accessed September 16, 2016, at http:// pubs.usgs.gov/ $\mathrm{tm} / 3 \mathrm{a} 23$.

Livingston, R.J., Niu, X., Lewis, F.G., and Woodsum, G.C., 1997, Freshwater input to a gulf estuary-Long-term control of trophic organization: Ecological Applications, v. 7, no. 1, p. 277-299.

Lorenzen, T.J., and Anderson, V.L., 1993, Design of experiments-A no-name approach: New York, Marcel Dekker, $414 \mathrm{p}$.

Mainstone, C.P., and Parr, William, 2002, Phosphorus in rivers-Ecology and management: Science of the Total Environment, v. 282-283, p. 25-47, accessed December 9, 2016, at http://www.sciencedirect.com/science/article/pii/ S0048969701009378.

Mayer, D.G., and Butler, D.G., 1993, Statistical validation: Ecological modelling, v. 68, no. 1-2, p. 21-32, accessed January 9, 2017, at http://www.sciencedirect.com/ science/article/pii/0304380093901052.

Miller, E.G., 1962, Observations of tidal flow in the Delaware River: U.S. Geological Survey Water-Supply Paper 1586-C, 26 p., accessed October 3, 2016, at http://pubs.usgs.gov/ wsp/1586c/report.pdf.

Montagna, P.A., and Kalke, R.D., 1992, The effect of freshwater inflow on meiofaunal and macrofaunal populations in the Guadalupe and Nueces Estuaries, Texas: Estuaries, v. 15, no. 3, p. 307-326.

Mueller, D.K., Schertz, T.L., Martin, J.D., and Sandstrom, M.W., 2015, Design, analysis, and interpretation of field quality-control data for water-sampling projects: U.S. Geological Survey Techniques and Methods, book 4, chap. C4, 54 p., accessed October 3, 2016, at http://dx.doi. org/10.3133/tm4C4. 
Mueller, D.S., Wagner, C.R., Rehmel, M.S., Oberg, K.A, and Rainville, Francois, 2013, Measuring discharge with acoustic Doppler current profilers from a moving boat (ver. 2.0, December 2013): U.S. Geological Survey Techniques and Methods, book 3, chap. A22, 95 p., accessed October 3, 2016, at http://dx.doi.org/10.3133/tm3A22.

National Oceanic and Atmospheric Administration, 2016, National Centers for Environmental InformationClimatological rankings, accessed September 16, 2016, at http://www.ncdc.noaa.gov/temp-and-precip/ climatological-rankings/.

Patton, C.J., and Kryskalla, J.R., 2003, Methods of analysis by the U.S. Geological Survey National Water Quality Laboratory-Evaluation of alkaline persulfate digestion as an alternative to Kjeldahl digestion for determination of total and dissolved nitrogen and phosphorus in water: U.S. Geological Survey Water-Resources Investigations Report 03-4174, 33 p.

Patton, C.J., and Kryskalla, J.R., 2011, Colorimetric determination of nitrate plus nitrite in water by enzymatic reduction, automated discrete analyzer methods: U.S. Geological Survey Techniques and Methods, book 5, chap. B8, 34 p. [Also available at https://pubs.usgs.gov/tm/05b08/.]

Peterson, B.J., Wollheim, W.M., Mulholland, P.J., Webster, J.R., Meyer, J.L., Tank, J.L., Martí, E., Bowden, W.B., Valett, H.M., Hershey, A.E., and McDowell, W.H., 2001, Control of nitrogen export from watersheds by headwater streams: Science, v. 292, no. 5514, p. 86-90.

Porterfield, George, 1972, Computation of fluvial-sediment discharge: Techniques of Water-Resources Investigations of the United States Geological Survey, book 3, chap. C3, 66 p., accessed October 6, 2016, at http://pubs.usgs.gov/ twri/twri3-c3/.

Powell, G. L., Matsumoto, Junji, and Brock, D. A., 2002, Methods for determining minimum freshwater inflow needs of Texas bays and estuaries: Estuaries, v. 25, no. 6, p. 1262-1274, accessed December 9, 2016, at http://link. springer.com/article/10.1007/BF02692223.

Rantz, S.E., and others, 1982a, Measurement and computation of streamflow-Volume 1 measurement of stage and discharge: U.S. Geological Survey Water-Supply Paper 2175, 284 p., accessed December 9, 2016, at http://pubs.usgs.gov/ wsp/wsp2175/pdf/WSP2175_volla.pdf.

Rantz, S.E., and others, 1982b, Measurement and computation of streamflow-Volume 2 computation of discharge: U.S. Geological Survey Water-Supply Paper 2175, 631 p., accessed December 9, 2016, at http://pubs.usgs.gov/wsp/ wsp2175/pdf/WSP2175_vol2a.pdf.
Rasmussen, P.P., Gray, J.R., Glysson, G.D., and Ziegler, A.C., 2009, Guidelines and procedures for computing time-series suspended-sediment concentrations and loads from instream turbidity-sensor and streamflow data: U.S. Geological Survey Techniques and Methods book 3, chap. C4, 53 p., accessed October 12, 2016, at http://pubs.usgs.gov/ $\mathrm{tm} / \mathrm{tm} 3 \mathrm{c} 4 /$.

Rus, D.L., Patton, C.J., Mueller, D.K., and Crawford, C.G., 2013, Assessing total nitrogen in surface-water samplesPrecision and bias of analytical and computational methods: U.S. Geological Survey Scientific Investigations Report 2012-5281, 38 p.

Sauer, V.B., and Turnipseed, D.P., 2010, Stage measurement at gaging stations: U.S. Geological Survey Techniques and Methods, book 3, chap. A7, 45 p., accessed October 3, 2016, at http://pubs.usgs.gov/tm/tm3-a7/.

Seitzinger, S. P., Harrison, J. A., Dumont, Egon, Beusen, A. H.W., and Bouwman, A. F., 2005, Sources and delivery of carbon, nitrogen, and phosphorus to the coastal zoneAn overview of Global Nutrient Export from Watersheds (NEWS) models and their application: Global Biogeochemical Cycles, v. 19, accessed November 28, 2016, at http:// onlinelibrary.wiley.com/doi/10.1029/2005GB002606/epdf.

Sharpley, A.N., Menzel, R.G., Smith, S.J., Rhoades, E.D., and Olness, A.E., 1981, The sorption of soluble phosphorus by soil material during transport in runoff from cropped and grassed watersheds: Journal of Environmental Quality, v. 10 , no. 2 , p. $211-215$.

Sklar, F.H., and Browder, J.A., 1998, Coastal environmental impacts brought about by alterations to freshwater flow in the Gulf of Mexico: Environmental Management, v. 22, no. 4 , p. 547-562.

Smith, V.H., Tilman, G.D., and Nekola, J.C., 1999, Eutrophication - Impacts of excess nutrient inputs on freshwater, marine, and terrestrial ecosystems: Environmental Pollution, v. 100, no. 1, p. 179-196.

Texas Parks and Wildlife Department, 1974, An analysis of Texas waterways - A report on the physical characteristics of rivers, streams, and bayous in Texas, accessed October 3, 2016, at http://tpwd.texas.gov/publications/pwdpubs/ pwd_rp_t3200_1047/index.phtml.

Texas Water Development Board, 2016, 2017 State water plan, water for Texas, 164 p., accessed September 21, 2016, at http://www.twdb.texas.gov/waterplanning/swp/2017/.

Topping, D.J., and Wright, S.A., 2016, Long-term continuous acoustical suspended-sediment measurements in riversTheory, application, bias, and error: U.S. Geological Survey Professional Paper 1823, 98 p., accessed November 28, 2016, at http://dx.doi.org/10.3133/pp1823. 
Trinity River Authority of Texas, 2012, Trinity River Basin master plan, 58 p., accessed September 21, 2016, at http:// www.trinityra.org/downloads/Master_Plan_2012.pdf.

U.S. Environmental Protection Agency, 1993, Method 365.1 determination of phosphorus by semi-automated colorimetry, revision 2.0, in O'Dell, J.W., ed., Methods for the determination of inorganic substances in environmental samples: U.S. Environmental Protection Agency EPA/600/R-93/100.

U.S. Fish and Wildlife Service, 2016, National Wetlands Inventory website, accessed September 21, 2016, at http:// www.fws.gov/wetlands/.

U.S. Geological Survey, variously dated, National field manual for the collection of water-quality data: U.S. Geological Survey Techniques of Water-Resources Investigations, book 9, chaps. A1-A10, accessed October 17, 2016, at http:// water.usgs.gov/owq/FieldManual/index.html.
U.S. Geological Survey, 2016, U.S. Geological Survey National Water Information System, accessed September 21, 2016, at http://dx.doi.org/10.5066/F7P55KJN.

Withers, P.J.A., and Jarvie, H.P., 2008, Delivery and cycling of phosphorus in rivers-A review: Science of the Total Environment, v. 400, no. 1, p. 379-395.

Wood, M.S., and Teasdale, G.N., 2013, Use of surrogate technologies to estimate suspended sediment in the Clearwater River, Idaho, and Snake River, Washington, 2008-10: U.S. Geological Survey Scientific Investigations Report 2013-5052, 30 p.

Xylem Analytics, 2016, YSI-Monitor, analyze, and protect the world's natural resources, accessed November 1, 2016, at http://www.sontek.com/.

Yang, S.L., Milliman, J. D., Li, P., and Xu, K., 2011, 50,000 Dams later-Erosion of the Yangtze River and its delta: Global and Planetary Change, v. 75, no. 1 p. 14-20. 


\section{Appendix 1. Model Archival Summary for Suspended-Sediment Concentration at U.S. Geological Survey Streamflow-Gaging Station 08067252 Trinity River at Wallisville, Texas}

This model archival summary documents the suspendedsediment concentration (SSC) model developed to compute 15-minute suspended-sediment concentration from May 16, 2014, at U.S. Geological Survey (USGS) streamflow-gaging station 08067252 Trinity River at Wallisville, Tex. The methods follow USGS guidance documented in USGS Techniques and Methods, book 3, chapter C5 (Landers and others, 2016).

\section{Site and Model Information}

Wallisville site (USGS streamflow-gaging station 08067252 Trinity River at Wallisville, Tex.)

Location: Latitude $29^{\circ} 49^{\prime} 52.71^{\prime \prime}$, longitude $94^{\circ} 45^{\prime} 14.89^{\prime \prime} \mathrm{W}$ NAD 27

Chambers County, Tex., Hydrologic Unit 12030203, at the Index Velocity gage approximately 2.5 miles upstream from a river-stage gage at the U.S. Army Corps of Engineers river lock and dam structure in the Trinity River, 3.9 river miles upstream from where the Trinity River enters Galveston Bay. Drainage area: 17,796 square miles

Contributing drainage area: 17,796 square miles

Date rating model was created: 05/18/2016

Model calibration data period: 05/16/2014-12/09/2015

Model application date: Starting 05/16/2014

Computed by: Zulimar Lucena, USGS, Houston, Tex.

(zlucena@usgs.gov)

Reviewed by: Mark Landers, USGS, Office of Surface Water, Atlanta, Ga.

Approved by: Robert Joseph, USGS, Texas Water Science Center Director, Austin, Tex.

\section{Physical Sampling Equipment and Sampling Details}

Suspended-sediment samples are collected bimonthly during the first year of model development and monthly during the second year of model calibration. After model calibration, samples are collected at least quarterly during low-flow conditions. During high-flow events, samples are collected at a higher frequency depending on the duration of the event. Samples are collected within each of five vertical sections in a cross section. The location of each vertical section is determined based on discharge and water velocity. When water velocities exceed 1.5 feet per second ( $\mathrm{ft} / \mathrm{s})$, the cross section is divided using the equal discharge increment method, and samples are collected using a US DH-2 sampler. When water velocities are below $1.5 \mathrm{ft} / \mathrm{s}$, grab samples are collected along the cross section using a weighted bottle sampler. Samples are analyzed for suspended-sediment concentrations (SSC) in the USGS Kentucky Water Science Center Sediment Laboratory.

\section{Surrogate Equipment and Setup Details}

A 1.5-megahertz (MHz) SonTek Argonaut-Side-Looker (SL) Acoustic Doppler velocity meter (ADVM) is installed at the site to compute discharge in cubic feet per second and obtain sediment backscatter data (table 1-1). The ADVM is bolted to a Cupronickel 2-inch diameter pipe that is pinned in place to a steel bracket welded onto the stream bulkhead on the right bank of the river. The Acoustic Doppler beams are horizontal and perpendicular to flow. The gage house, containing a battery, solar panel, Data Collection Platform, and regulator, is located on the right bank, approximately 10 feet from the ADVM. The ADVM configuration settings are provided (table 1-2).

\section{Model Calibration Dataset}

All data were collected using USGS protocols and are available on the USGS National Water Information System (NWIS) database (U.S. Geological Survey, 2016). The dataset used to develop the regression model consisted of 35 measurements of SSC (equal discharge increment and grab samples) and ADVM data collected from May 16, 2014, to December 9, 2016. Two samples were excluded because of missing acoustic backscatter data. Two samples were removed based on outlier diagnostic indicators and further evaluation of the data. From the 35 samples, 31 were used in the model calibration dataset.

The 31 samples were collected over the range of continuously observed streamflow conditions as shown in the duration curves below. The duration curves were developed for streamflow and sediment corrected backscatter () data collected in May 2014-December 2015 (fig. 1-1). Summary statistics for SSC data used in the model calibration dataset are provided (table 1-3). 
Table 1-1. Acoustic Doppler velocity meter (ADVM) specifications.

\begin{tabular}{lccccc}
\hline Make & Model & $\begin{array}{c}\text { Frequency } \\
\text { (MHz) }\end{array}$ & Serial number & $\begin{array}{c}\text { Effective trans- } \\
\text { ducer diameter } \\
\text { (meters) }\end{array}$ & $\begin{array}{c}\text { Slant beam angle } \\
\text { (degrees) }\end{array}$ \\
\hline SonTek & Argonaut SL & 1.5 & E3902 & 0.03 & 25 \\
\hline
\end{tabular}

Table 1-2. Acoustic Doppler velocity meter (ADVM) configuration settings.

\begin{tabular}{ccccc}
\hline $\begin{array}{c}\text { Blanking } \\
\text { distance } \\
\text { (meters) }\end{array}$ & $\begin{array}{c}\text { Number } \\
\text { of cells }\end{array}$ & $\begin{array}{c}\text { Cell size } \\
\text { (meters) }\end{array}$ & $\begin{array}{c}\text { Measurement averaging period } \\
\text { (seconds) }\end{array}$ & \multicolumn{1}{c}{$\begin{array}{c}\text { Measurement interval } \\
\text { (seconds) }\end{array}$} \\
\hline 3.05 & 5 & 3.05 & $\begin{array}{l}600(\text { from } 5 / 16 / 2014 \text { to } 1 / 15 / 2015) \\
\text { installed }\end{array}$ & $900($ from $5 / 16 / 2014$ to $1 / 15 / 2015)$ \\
& & & $60($ from $1 / 16 / 2015$ to $8 / 5 / 2015)$ & $60($ from $1 / 16 / 2015$ to $8 / 5 / 2015)$ \\
\hline
\end{tabular}
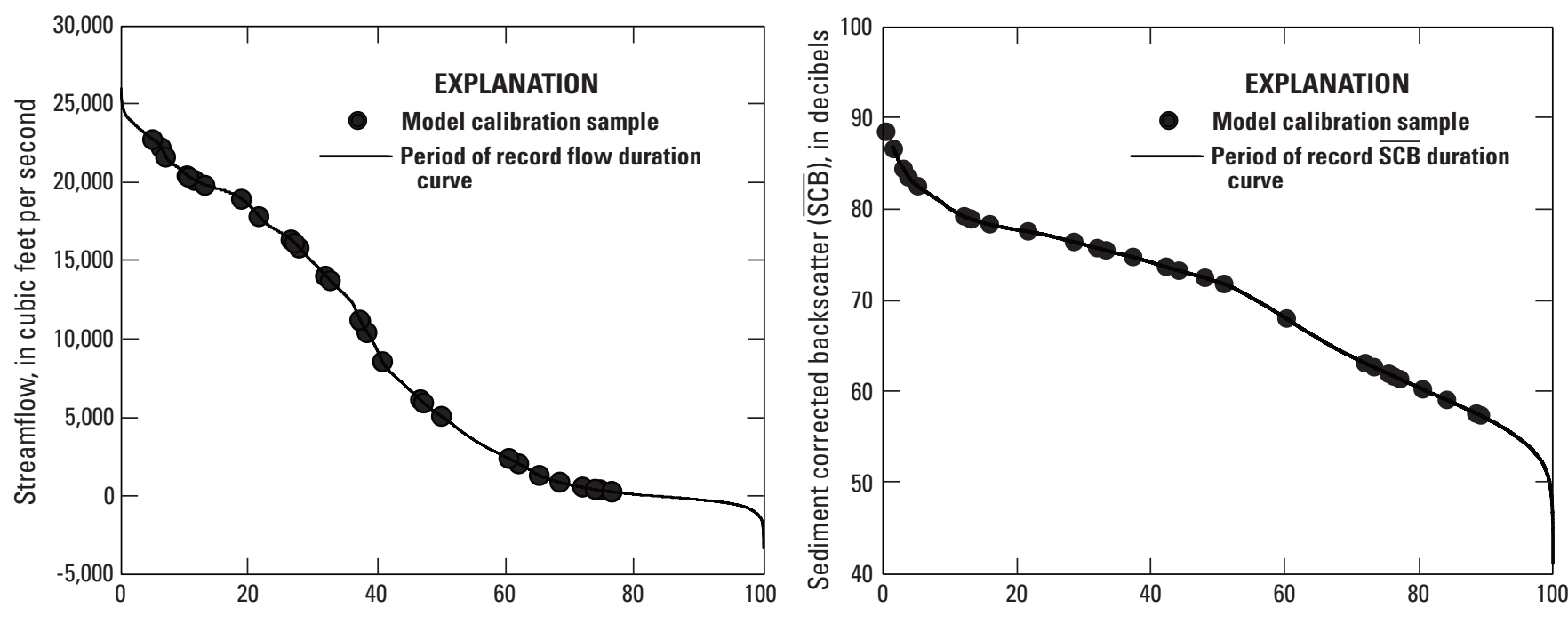

Frequency of exceedance, in percent

Figure 1-1. Streamflow and sediment corrected backscatter duration curves at U.S. Geological Survey streamflowgaging station 08067252 Trinity River at Wallisville, Texas, May 2014-December 2015.

Table 1-3. Summary statistics for suspended-sediment concentration data collected at U.S. Geological Survey streamflow-gaging station 08067252 Trinity River at Wallisville, Texas, May 2014-December 2015.

\begin{tabular}{cc}
\hline Summary statistic & $\begin{array}{c}\text { Suspended sediment concentration } \\
\text { (milligrams per liter) }\end{array}$ \\
\hline Minimum & 5.0 \\
Maximum & 453 \\
Median & 65.0 \\
Mean & 11.3 \\
Count & 31 \\
\hline
\end{tabular}


Suspended-sediment particles smaller than 0.0625 millimeter $(\mathrm{mm})$ were measured for 27 samples and ranged from 37 to 100 percent, with a median of 85.5 . The percentage of fine-sized particles decreased as discharge increased. Full-size analysis was also performed for six samples between April 3, 2015, and June 10, 2015 (table 4). For these samples, the fraction of sediment particles smaller than fine sand (smaller than $0.25 \mathrm{~mm}$ ) ranged from 96 to 100 percent.

\section{Model Development}

Suspended-sediment concentrations at the site are computed from a calibrated regression model between streamflow, SSCs, and continuously measured surrogates. The model was developed by the evaluation of mean sediment corrected backscatter $(\overline{S C B})$, sediment attenuation coefficient (SAC), and streamflow as explanatory variables for SSC.
By using the Surrogate Analysis and Index Developer (SAID) tool (version 1.0), $\overline{S C B}$ was calculated from measured backscatter following the methods described in Landers and others (2016). The processing settings used in the SAID tool are shown (table 1-4).

The SAID tool was also used to develop an ordinary least squares linear regression analysis, which examined streamflow, $\mathrm{SAC}$, and $\overline{S C B}$ as explanatory variables for estimating SSC. Combinations of these three variables were evaluated to determine the best explanatory variables for SSC. A multiple linear regression model with a combination of streamflow and $\overline{S C B}$ as explanatory variables was determined to be the best model based on adjusted coefficient of determination $\left(\mathrm{R}^{2}\right)$, significance tests, model root mean square error, residual plots, and correlation of explanatory variables. All considered models were evaluated using these statistical measures and are included (table 1-5).

Table 1-4. Acoustic Doppler velocity meter settings used to process backscatter data with the Surrogate Analysis and Index Developer tool.

[Avg., average calculated from the two Acoustic Doppler beams; WCB, water corrected backscatter; SNR, signal to noise ratio]

\begin{tabular}{cccccc}
\hline $\begin{array}{c}\text { Acoustic Doppler } \\
\text { beam used }\end{array}$ & $\begin{array}{c}\text { Moving average } \\
\text { span }\end{array}$ & $\begin{array}{c}\text { Backscatter values } \\
\text { (SNR or amplitude) }\end{array}$ & Cells used & Near field correction & $\begin{array}{c}\text { WCB profile } \\
\text { adjustment }\end{array}$ \\
\hline Avg. & 1 & SNR & $1-5$ & Yes & Yes \\
\hline
\end{tabular}

Table 1-5. Alternative models considered for estimating suspended-sediment concentrations at U.S. Geological Survey streamflowgaging station 08067252 Trinity River at Wallisville, Texas.

$\left[\mathrm{R}^{2}\right.$, coefficient of determination; SSC, suspended-sediment concentration; $\overline{S C B}$, mean sediment corrected backscatter; -, not applicable; $\log _{10}$, base-10 logarithm; Q, discharge; SAC, sediment attenuation coefficient]

\begin{tabular}{llcccc}
\hline $\begin{array}{c}\text { Response } \\
\text { variable }\end{array}$ & $\begin{array}{c}\text { Explanatory } \\
\text { variables }\end{array}$ & Root mean square error & $\mathbf{R}^{2}$ & Adjusted $\mathbf{R}^{2}$ & $\begin{array}{c}\text { Variance inflation } \\
\text { factor }\end{array}$ \\
\hline $\mathrm{SSC}$ & $\overline{S C B}$ & 82.0 & 0.58 & 0.57 & - \\
$\log _{10} \mathrm{SSC}$ & $\overline{S C B}$ & 0.229 & 0.87 & 0.87 & - \\
$\log _{10} \mathrm{SSC}$ & $\log _{10} \mathrm{Q}$ & 0.281 & 0.79 & 0.79 & - \\
$\log _{10} \mathrm{SSC}$ & $\mathrm{Q}$ & 0.276 & 0.81 & 0.80 & - \\
$\log _{10} \mathrm{SSC}$ & $\mathrm{SAC}$ & 0.590 & 0.14 & 0.11 & - \\
$\log _{10} \mathrm{SSC}$ & $\overline{S C B}, \mathrm{SAC}$ & 0.223 & 0.88 & 0.87 & $1.0,1.0$ \\
$\log _{10} \mathrm{SSC}$ & $\overline{S C B}, \log _{10} \mathrm{Q}$ & 0.209 & 0.89 & 0.88 & $1.6,1.6$ \\
$\log _{10} \mathrm{SSC}$ & $\overline{S C B}, \mathrm{Q}, \mathrm{SAC}$ & 0.213 & 0.89 & 0.87 & $2.5,2.4,3.9$ \\
\hline
\end{tabular}




\section{Model Summary}

The model of SSC for USGS streamflow-gaging station 08067252 Trinity River at Wallisville, Tex., has an adjusted coefficient of determination of 0.92 and is its equation in linear form is:

$$
\log _{10} S S C=-1.57+0.416 \overline{S C B}+0.000031 Q
$$

where

SSC is the suspended-sediment concentration, in milligrams per liter;

$\overline{S C B}$ is the mean sediment corrected backscatter, in decibels; and

$Q \quad$ is the computed discharge, in cubic feet per second.

The SSC was transformed before regression analysis, and the predicted mean of the variable may be biased. To account for this bias, a nonparametric smearing bias correction factor (BCF) of 1.09 was applied to the predicted variable (table 1-6). Detailed statistical information for the selected model and statistical measures useful for evaluating the model are summarized (table 1-7).

Table 1-6. Suspended-sediment regression model and nonparametric smearing bias correction factor for U.S. Geological Survey streamflow-gaging station 08067252 Trinity River at Wallisville, Texas.

[BCF, nonparametric smearing bias correction factor; SSC, suspended-sediment concentration; $\overline{S C B}$, sediment corrected backscatter; Q, discharge]

\begin{tabular}{cccc}
\hline Start date & End date & Linear regression model & BCF \\
\hline $05 / 16 / 2014$ & - & $S S C=0.0269 \times 10^{0.0416 \overline{S C B}+0.000031 Q} \times B C F$ & 1.09 \\
\hline
\end{tabular}


Table 1-7. Summary statistics for the selected model and statistical measures to evaluate the suspended-sediment regression model for U.S. Geological Survey streamflow-gaging station 08067252 Trinity River at Wallisville, Texas.

[SSC, suspended-sediment-concentration; $\overline{S C B}$, sediment corrected backscatter; $\mathrm{Q}$, discharge; $\mathrm{dB}$, decibels; mg/L, milligrams per liter; $\mathrm{R}^{2}$, coefficient of determination; fts/s, cubic feet per second; E, exponential; Cook's D, Cook's distance; DFFITS, difference in fit statistic]

\begin{tabular}{|c|c|c|c|c|c|c|c|}
\hline \multicolumn{8}{|c|}{ Rating equation form } \\
\hline \multicolumn{8}{|c|}{$\log _{10} \mathrm{SSC}=-1.57+0.000031 \mathrm{Q}+0.0416 \overline{S C B}$} \\
\hline \multicolumn{8}{|c|}{ Explanatory and response variable summary statistics } \\
\hline & & $\mathbf{0}\left(\mathbf{f t}^{3} / \mathbf{s}\right)$ & $\overline{S C B}(\mathrm{~dB})$ & $\log _{10}(S S C)$ & SSC (mg/L) & & \\
\hline Minimum & & -691 & 55.1 & 0.699 & 5 & & \\
\hline 1st quartile & & 1,050 & 62.3 & 1.089 & 12.5 & & \\
\hline Median & & 10,600 & 74.7 & 1.813 & 65 & & \\
\hline Mean & & 9,730 & 71.8 & 1.711 & 113 & & \\
\hline 3rd quartile & & 17,000 & 78.7 & 2.257 & 181 & & \\
\hline Maximum & & 23,700 & 86.5 & 2.656 & 453 & & \\
\hline \multicolumn{8}{|c|}{ Rating calibration } \\
\hline \multicolumn{2}{|c|}{$\begin{array}{l}\text { Number of } \\
\text { observations }\end{array}$} & 31 & & & & & \\
\hline \multicolumn{2}{|c|}{ Error degrees of freedom } & 28 & & & & & \\
\hline \multicolumn{2}{|c|}{ Root mean square error } & 0.181 & & & & & \\
\hline \multicolumn{2}{|c|}{$\mathrm{R}^{2}$} & 0.92 & & & & & \\
\hline \multicolumn{2}{|l|}{ Adjusted $\mathrm{R}^{2}$} & 0.92 & & & & & \\
\hline \multicolumn{2}{|c|}{ F-statistic vs. constant model } & 163 & & & & & \\
\hline \multicolumn{2}{|l|}{ p-value } & $3.87 \mathrm{E}-16$ & & & & & \\
\hline \multicolumn{2}{|c|}{ Variance inflation factor $(\mathrm{Q})}$, & $2.41,2.41$ & & & & & \\
\hline \multicolumn{8}{|c|}{ Estimated coefficients } \\
\hline & \multicolumn{2}{|c|}{ Estimate } & $\begin{array}{l}\text { Standard error of } \\
\text { coefficients }\end{array}$ & Student's t-value & p-value & $\begin{array}{l}\text { Lower value of } \\
90 \text { percent con- } \\
\text { fidence interval }\end{array}$ & $\begin{array}{l}\text { Upper value of } \\
90 \text { percent confi- } \\
\text { dence interval }\end{array}$ \\
\hline (Intercept) & -1.57 & & 0.410 & -3.8206 & 0.0007 & -2.26 & -0.870 \\
\hline Q & $3.01 \mathrm{E}-05$ & & 7.11E-06 & 4.2374 & 0.0002 & 0.0000 & 0.0000 \\
\hline$\overline{S C B}$ & 0.0416 & & 0.00650 & 6.4312 & 0.0000 & 0.0306 & 0.0526 \\
\hline \multicolumn{2}{|c|}{$\begin{array}{l}\text { Nonparametric smearing } \\
\text { bias } \\
\text { correction factor }\end{array}$} & 1.088 & & & & & \\
\hline \multicolumn{2}{|c|}{$\begin{array}{l}\text { Probability plot correlation } \\
\text { coefficient }\end{array}$} & 0.983 & & & & & \\
\hline \multicolumn{8}{|c|}{ Variance-covariance matrix } \\
\hline & (Intercept & Discharge & $\overline{S C B}$ & & & \\
\hline \multicolumn{2}{|l|}{ (Intercept) } & 0.168 & $2.23 \mathrm{E}-06$ & -0.00260 & & & \\
\hline \multirow[t]{2}{*}{ Discharge } & & $2.23 \mathrm{E}-06$ & $5.06 \mathrm{E}-11$ & $-3.79 \mathrm{E}-08$ & & & \\
\hline & & -0.00260 & $-3.79 \mathrm{E}-08$ & $4.18 \mathrm{E}-05$ & & & \\
\hline \multicolumn{8}{|c|}{ Test Criteria } \\
\hline \multicolumn{3}{|c|}{ High leverage } & 0.290 & & & & \\
\hline \multicolumn{3}{|c|}{ Extreme outlier (Standardized residual) } & $\begin{array}{l}3 \\
\text { absolute value) }\end{array}$ & & & & \\
\hline \multicolumn{3}{|c|}{ High influence (Cook's D) } & 2.12 & & & & \\
\hline \multicolumn{3}{|c|}{ High influence (DFFITS) } & 0.622 & & & & \\
\hline
\end{tabular}


Residual plots showing distribution of residuals throughout the period of the calibration dataset and the range of predicted log transformed SSC concentrations and a normal quantile plot are provided (fig. 1-2), along with a scatter plot of observed and computed SSC values (fig. 1-3). Model calibration data, SSC predicted values, and selected statistics for individual observations are provided (table 1-8).

\section{Suspended-Sediment Concentration Record}

The continuous time-series SSC record is computed using the regression model from May 16, 2014, through December 31, 2015. Data are computed at 15-minute intervals. The continuous SSC record at the Wallisville site from January to December 2015 is depicted in figure 1-4.

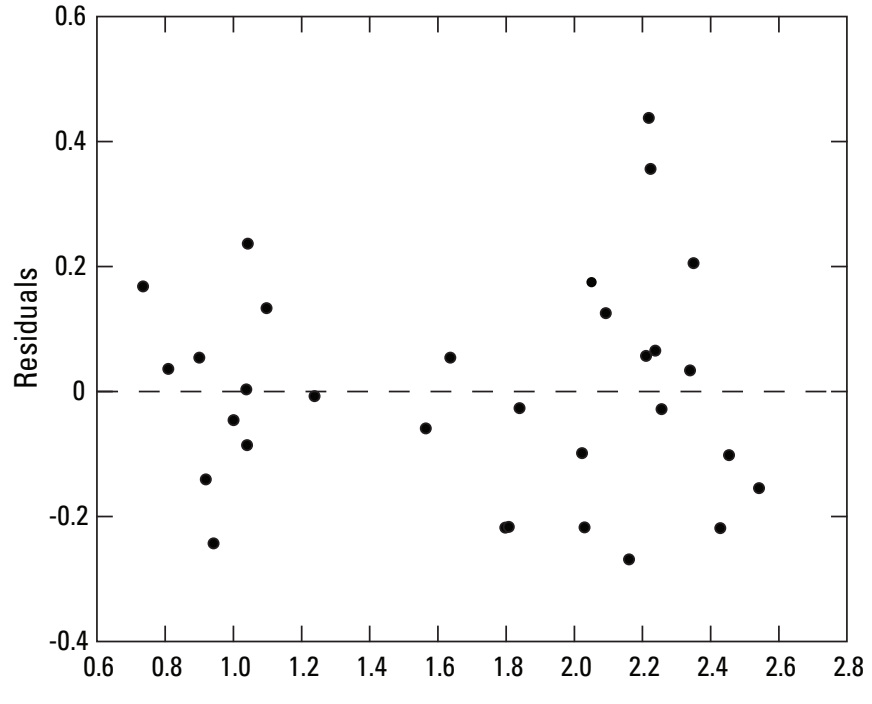

Predicted $\log ^{10}$ of suspended-sediment concentration
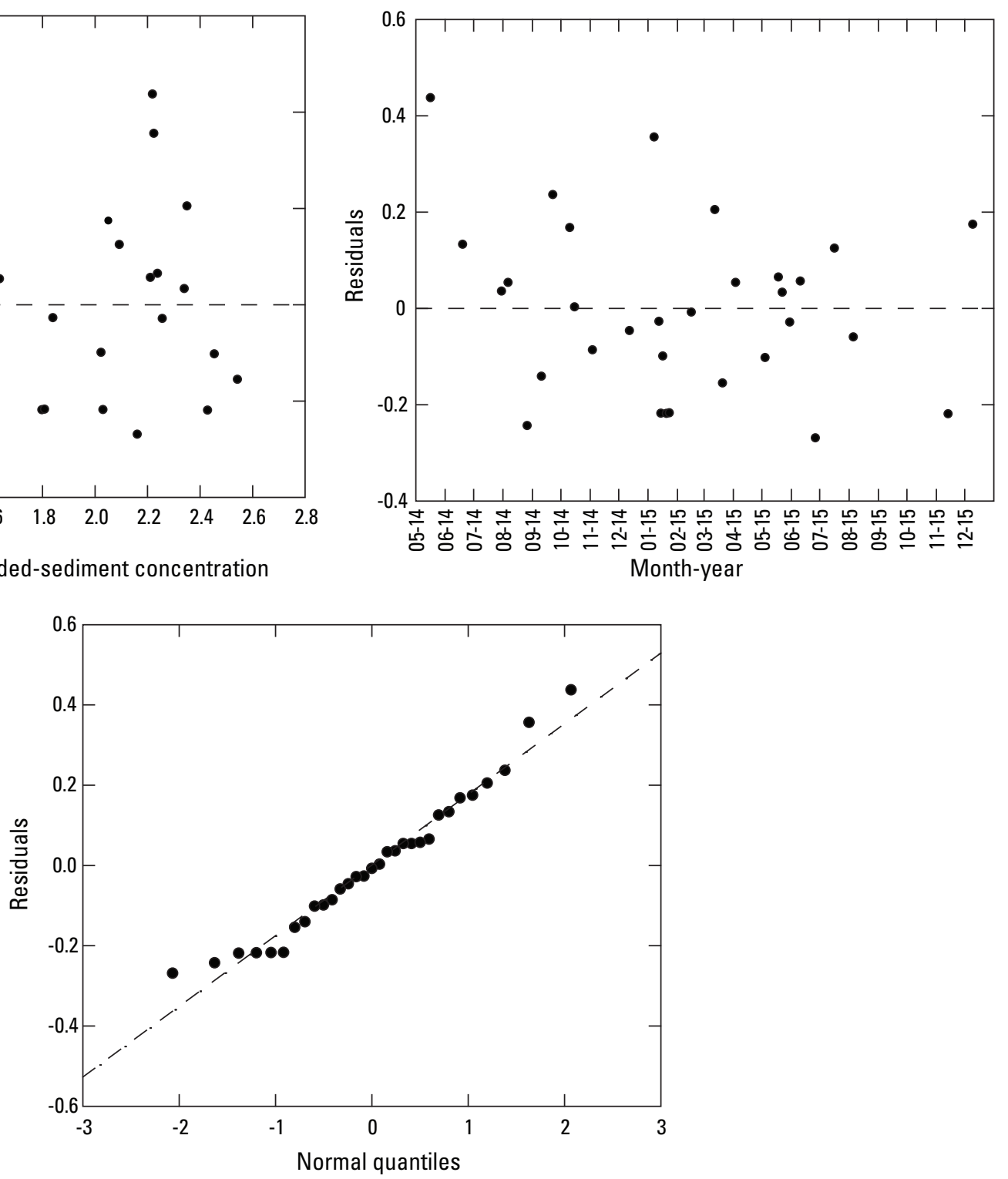

Figure 1-2. Diagnostics plots for selected regression model developed for U.S. Geological Survey streamflow-gaging station 08067252 Trinity River at Wallisville, Texas. 


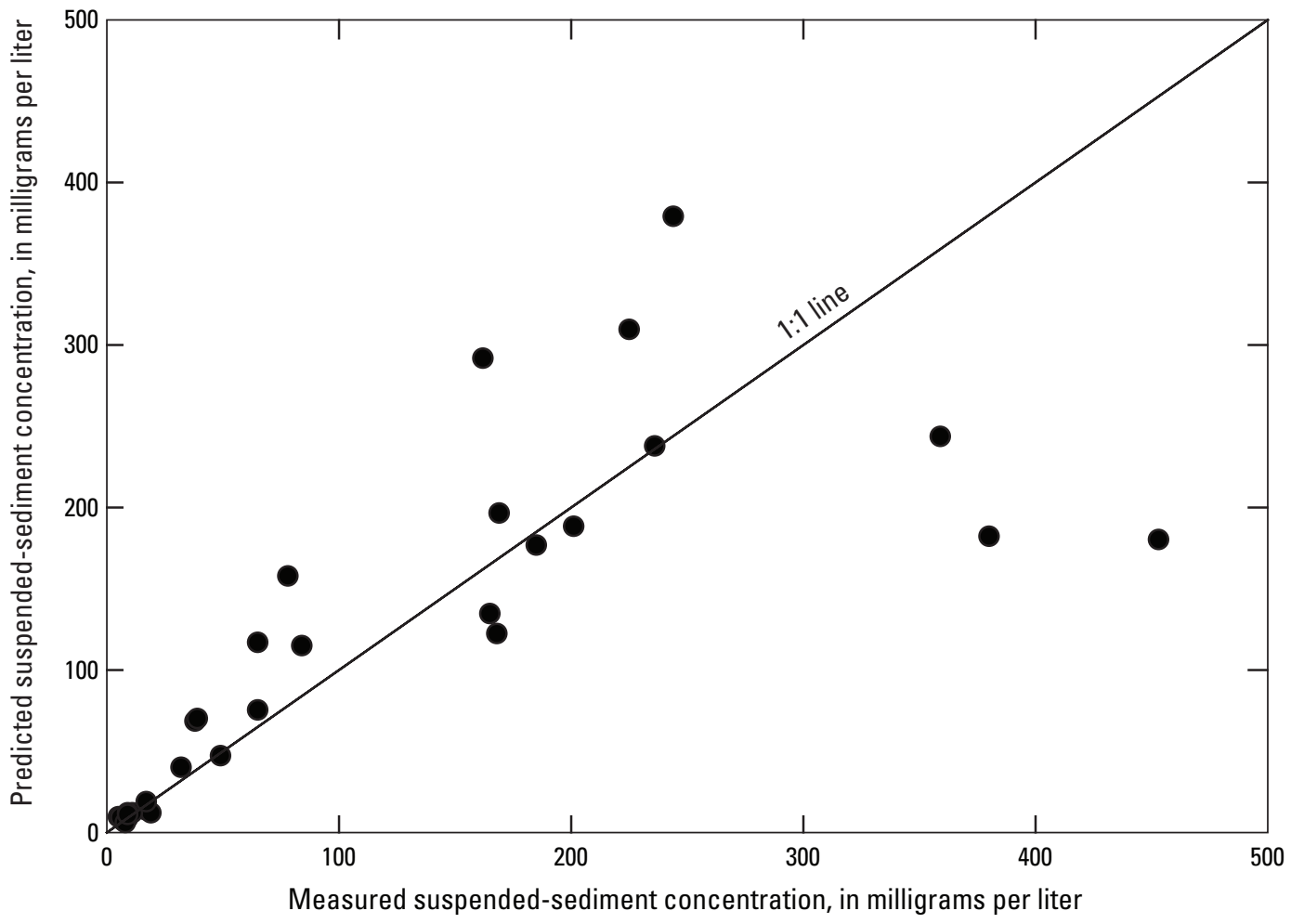

Figure 1-3. Model predicted and measured suspended-sediment concentrations at U.S. Geological Survey streamflow-gaging station 08067252 Trinity River at Wallisville, Texas

Table 1-8. Calibration data used for suspended-sediment model development at U.S. Geological Survey streamflow-gaging station 08067252 Trinity River at Wallisville, Texas, and selected statistical results.

[hr, hour; CST, central standard time; SSC, suspended-sediment concentration; $\mathrm{mg} / \mathrm{L}$, milligrams per liter; $\overline{S C B}$, mean sediment corrected backscatter; $\mathrm{dB}$, decibels; $\mathrm{ft}^{3} / \mathrm{s}$, cubic feet per second; $\mathrm{mg} / \mathrm{L}$, milligrams per liter; $\log _{10}$, base-10 logarithm, Cook's D, Cook's distance; DFFITS, difference in fit statistic]

\begin{tabular}{|c|c|c|c|c|c|c|c|c|c|c|c|c|}
\hline \multirow{2}{*}{\multicolumn{3}{|c|}{$\begin{array}{l}\text { Suspended-sediment sample } \\
\text { Date and } \\
\text { time Measured SSC }\end{array}$}} & \multirow{3}{*}{\multicolumn{2}{|c|}{$\begin{array}{cc}\text { Explanatory variables } \\
\overline{S C B} & \begin{array}{c}\text { Computed } \\
\text { Discharge }\end{array} \\
(\mathrm{dB}) & \left(\mathrm{ft}^{3} / \mathrm{s}\right)\end{array}$}} & \multicolumn{8}{|c|}{ Model results } \\
\hline & & & & & \multicolumn{2}{|c|}{ Predicted } & \multirow{2}{*}{$\begin{array}{l}\text { Residuals } \\
\log ^{10}\end{array}$} & \multirow{2}{*}{$\begin{array}{l}\text { Standard- } \\
\text { ized residu- } \\
\text { als }\end{array}$} & \multirow{2}{*}{$\begin{array}{l}\text { Normal } \\
\text { quantiles }\end{array}$} & \multirow[t]{2}{*}{ Leverage } & \multirow[t]{2}{*}{ Cook's D } & \multirow[t]{2}{*}{ DFFITS } \\
\hline (CST) & $(\mathrm{mg} / \mathrm{L})$ & $\log ^{10}$ & & & $(\mathrm{mg} / \mathrm{L})$ & $\log ^{10}$ & & & & & & \\
\hline $\begin{array}{l}5 / 16 / 2014 \\
11: 35\end{array}$ & 453 & 2.656 & 81.73 & 12,900 & 180 & 2.219 & 0.437 & 2.538 & 2.070 & 0.100 & 0.239 & 0.948 \\
\hline $\begin{array}{l}6 / 19 / 2014 \\
12: 40\end{array}$ & 17 & 1.230 & 62.68 & 1,960 & 14 & 1.097 & 0.133 & 0.759 & 0.801 & 0.067 & 0.014 & 0.203 \\
\hline $\begin{array}{l}7 / 30 / 2014 \\
11: 45\end{array}$ & 7 & 0.845 & 57.40 & -310 & 7 & 0.809 & 0.036 & 0.210 & 0.243 & 0.117 & 0.002 & 0.075 \\
\hline $\begin{array}{l}8 / 6 / 2014 \\
11: 13\end{array}$ & 9 & 0.954 & 59.61 & -337 & 9 & 0.900 & 0.054 & 0.312 & 0.413 & 0.094 & 0.003 & 0.099 \\
\hline $\begin{array}{l}8 / 26 / 2014 \\
11: 38\end{array}$ & 5 & 0.699 & 60.28 & 132 & 10 & 0.942 & -0.243 & -1.402 & -1.633 & 0.088 & 0.063 & -0.443 \\
\hline $\begin{array}{l}9 / 10 / 2014 \\
12: 13\end{array}$ & 6 & 0.778 & 59.13 & 943 & 9 & 0.919 & -0.141 & -0.817 & -0.695 & 0.098 & 0.024 & -0.268 \\
\hline $\begin{array}{l}9 / 22 / 2014 \\
14: 00\end{array}$ & 19 & 1.279 & 61.20 & 2,190 & 12 & 1.042 & 0.236 & 1.355 & 1.383 & 0.078 & 0.052 & 0.401 \\
\hline $\begin{array}{l}10 / 10 / 2014 \\
11: 46\end{array}$ & 8 & 0.903 & 55.06 & 469 & 6 & 0.735 & 0.168 & 1.009 & 0.917 & 0.163 & 0.066 & 0.445 \\
\hline
\end{tabular}


Table 1-8. Calibration data used for suspended-sediment model development at U.S. Geological Survey streamflow-gaging station 08067252 Trinity River at Wallisville, Texas, and selected statistical results.—Continued

[hr, hour; CST, central standard time; SSC, suspended-sediment concentration; mg/L, milligrams per liter; $\overline{S C B}$, mean sediment corrected backscatter; $\mathrm{dB}$, decibels; $\mathrm{ft}^{3} / \mathrm{s}$, cubic feet per second; mg/L, milligrams per liter; $\log _{10}$, base-10 logarithm, Cook's D, Cook's distance; DFFITS, difference in fit statistic]

\begin{tabular}{|c|c|c|c|c|c|c|c|c|c|c|c|c|}
\hline \multirow{2}{*}{\multicolumn{3}{|c|}{$\begin{array}{l}\text { Suspended-sediment sample } \\
\text { Date and } \\
\text { time Measured SSC }\end{array}$}} & \multirow{3}{*}{\multicolumn{2}{|c|}{$\begin{array}{cc}\text { Explanatory variables } \\
\begin{array}{r}\text { Computed } \\
\text { Discharge }\end{array} \\
\text { (dB) } \quad\left(\mathrm{ft}^{3} / \mathrm{s}\right)\end{array}$}} & \multicolumn{8}{|c|}{ Model results } \\
\hline & & & & & \multicolumn{2}{|c|}{ Predicted } & \multirow{2}{*}{$\begin{array}{l}\text { Residuals } \\
\log ^{10}\end{array}$} & \multirow{2}{*}{$\begin{array}{l}\text { Standard- } \\
\text { ized residu- } \\
\text { als }\end{array}$} & \multirow{2}{*}{$\begin{array}{c}\text { Normal } \\
\text { quantiles }\end{array}$} & \multirow[t]{2}{*}{ Leverage } & \multirow[t]{2}{*}{ Cook's D } & \multirow[t]{2}{*}{ DFFITS } \\
\hline (CST) & (mg/L) & $\log ^{10}$ & & & (mg/L) & $\log ^{10}$ & & & & & & \\
\hline $\begin{array}{l}10 / 15 / 2014 \\
12: 27\end{array}$ & 11 & 1.041 & 62.13 & 770 & 12 & 1.039 & 0.003 & 0.016 & 0.080 & 0.075 & 0.000 & 0.005 \\
\hline $\begin{array}{l}11 / 3 / 2014 \\
11: 24\end{array}$ & 9 & 0.954 & 62.68 & 81 & 12 & 1.040 & -0.086 & -0.494 & -0.413 & 0.078 & 0.007 & -0.142 \\
\hline $\begin{array}{l}12 / 12 / 2014 \\
11: 35\end{array}$ & 9 & 0.954 & 60.78 & 1,370 & 11 & 1.000 & -0.046 & -0.265 & -0.243 & 0.082 & 0.002 & -0.078 \\
\hline $\begin{array}{l}1 / 7 / 2015 \\
12: 22\end{array}$ & 380 & 2.580 & 80.55 & 14,700 & 182 & 2.224 & 0.356 & 2.029 & 1.633 & 0.067 & 0.099 & 0.579 \\
\hline $\begin{array}{l}1 / 12 / 2015 \\
11: 29\end{array}$ & 65 & 1.813 & 73.71 & 11,400 & 75 & 1.840 & -0.027 & -0.152 & -0.080 & 0.034 & 0.000 & -0.028 \\
\hline $\begin{array}{l}1 / 14 / 2015 \\
13: 12\end{array}$ & 65 & 1.813 & 78.87 & 10,600 & 117 & 2.031 & -0.218 & -1.252 & -1.047 & 0.083 & 0.047 & -0.380 \\
\hline $\begin{array}{l}1 / 16 / 2015 \\
11: 06\end{array}$ & 84 & 1.924 & 78.33 & 11,100 & 115 & 2.023 & -0.099 & -0.565 & -0.502 & 0.069 & 0.008 & -0.151 \\
\hline $\begin{array}{l}1 / 20 / 2015 \\
12: 20\end{array}$ & 38 & 1.580 & 74.76 & 8,550 & 68 & 1.798 & -0.218 & -1.234 & -1.198 & 0.053 & 0.029 & -0.296 \\
\hline $\begin{array}{l}1 / 23 / 2015 \\
11: 42\end{array}$ & 39 & 1.591 & 76.37 & 6,670 & 70 & 1.808 & -0.217 & -1.263 & -0.917 & 0.105 & 0.062 & -0.438 \\
\hline $\begin{array}{l}2 / 15 / 2015 \\
15: 20\end{array}$ & 17 & 1.230 & 68.00 & -691 & 19 & 1.238 & -0.008 & -0.047 & 0.000 & 0.126 & 0.000 & -0.017 \\
\hline $\begin{array}{l}3 / 12 / 2015 \\
12: 10\end{array}$ & 359 & 2.555 & 83.44 & 14,900 & 244 & 2.350 & 0.205 & 1.193 & 1.198 & 0.107 & 0.057 & 0.415 \\
\hline $\begin{array}{l}3 / 20 / 2015 \\
12: 24\end{array}$ & 244 & 2.387 & 86.54 & 17,000 & 379 & 2.542 & -0.155 & -0.920 & -0.801 & 0.142 & 0.047 & -0.374 \\
\hline $\begin{array}{l}4 / 3 / 2015 \\
10: 55\end{array}$ & 49 & 1.690 & 73.24 & 5,290 & 47 & 1.636 & 0.054 & 0.309 & 0.327 & 0.080 & 0.003 & 0.089 \\
\hline $\begin{array}{l}5 / 4 / 2015 \\
12: 50\end{array}$ & 225 & 2.352 & 84.42 & 17,000 & 310 & 2.454 & -0.102 & -0.594 & -0.596 & 0.104 & 0.014 & -0.200 \\
\hline $\begin{array}{l}5 / 18 / 2015 \\
13: 00\end{array}$ & 201 & 2.303 & 76.76 & 20,400 & 188 & 2.238 & 0.065 & 0.381 & 0.596 & 0.116 & 0.006 & 0.136 \\
\hline $\begin{array}{l}5 / 22 / 2015 \\
11: 45\end{array}$ & 236 & 2.373 & 79.13 & 20,500 & 238 & 2.340 & 0.033 & 0.193 & 0.161 & 0.097 & 0.001 & 0.062 \\
\hline $\begin{array}{l}5 / 30 / 2015 \\
11: 30\end{array}$ & 169 & 2.228 & 77.35 & 20,200 & 196 & 2.257 & -0.029 & -0.167 & -0.161 & 0.106 & 0.001 & -0.056 \\
\hline $\begin{array}{l}6 / 10 / 2015 \\
14: 15\end{array}$ & 185 & 2.267 & 75.44 & 21,300 & 177 & 2.210 & 0.057 & 0.340 & 0.502 & 0.158 & 0.007 & 0.145 \\
\hline $\begin{array}{l}6 / 26 / 2015 \\
12: 57\end{array}$ & 78 & 1.892 & 74.76 & 20,600 & 158 & 2.161 & -0.269 & -1.607 & -2.070 & 0.151 & 0.153 & -0.697 \\
\hline $\begin{array}{l}7 / 16 / 2015 \\
12: 59\end{array}$ & 165 & 2.217 & 75.72 & 17,000 & 135 & 2.092 & 0.125 & 0.714 & 0.695 & 0.067 & 0.012 & 0.190 \\
\hline $\begin{array}{l}8 / 5 / 2015 \\
12: 20\end{array}$ & 32 & 1.505 & 71.77 & 4,920 & 40 & 1.564 & -0.059 & -0.338 & -0.327 & 0.067 & 0.003 & -0.089 \\
\hline
\end{tabular}


Table 1-8. Calibration data used for suspended-sediment model development at U.S. Geological Survey streamflow-gaging station 08067252 Trinity River at Wallisville, Texas, and selected statistical results. - Continued

[hr, hour; CST, central standard time; SSC, suspended-sediment concentration; mg/L, milligrams per liter; $\overline{S C B}$, mean sediment corrected backscatter; dB, decibels; ft $\mathrm{ft}^{3} / \mathrm{s}$, cubic feet per second; $\mathrm{mg} / \mathrm{L}$, milligrams per liter; $\log _{10}$, base-10 logarithm, Cook's D, Cook's distance; DFFITS, difference in fit statistic]

\begin{tabular}{|c|c|c|c|c|c|c|c|c|c|c|c|c|}
\hline \multicolumn{3}{|c|}{ Suspended-sediment sample } & \multirow{2}{*}{\multicolumn{2}{|c|}{$\begin{array}{r}\text { Explanatory variables } \\
\begin{array}{r}\text { Computed } \\
\text { Discharge }\end{array}\end{array}$}} & \multicolumn{8}{|c|}{ Model results } \\
\hline \multirow{2}{*}{$\begin{array}{l}\text { Date and } \\
\text { time } \\
\text { (24hr) } \\
\text { (CST) }\end{array}$} & \multicolumn{2}{|c|}{ Measured SSC } & & & \multicolumn{2}{|c|}{ Predicted } & \multirow{2}{*}{$\begin{array}{c}\text { Residuals } \\
\log ^{10}\end{array}$} & \multirow{2}{*}{$\begin{array}{l}\text { Standard- } \\
\text { ized residu- } \\
\text { als }\end{array}$} & \multirow{2}{*}{$\begin{array}{c}\text { Normal } \\
\text { quantiles }\end{array}$} & \multirow[t]{2}{*}{ Leverage } & \multirow[t]{2}{*}{ Cook's D } & \multirow[t]{2}{*}{ DFFITS } \\
\hline & $(\mathrm{mg} / \mathrm{L})$ & $\log ^{10}$ & (dB) & $\left(\mathrm{ft}^{3} / \mathrm{s}\right)$ & $(\mathrm{mg} / \mathrm{L})$ & $\log ^{10}$ & & & & & & \\
\hline $\begin{array}{l}11 / 13 / 2015 \\
12: 45\end{array}$ & 162 & 2.210 & 78.95 & 23,700 & 292 & 2.429 & -0.219 & -1.322 & -1.383 & 0.167 & 0.117 & -0.600 \\
\hline $\begin{array}{l}12 / 9 / 2015 \\
11: 55\end{array}$ & 168 & 2.225 & 75.22 & 16,300 & 122 & 2.051 & 0.175 & 0.992 & 1.047 & 0.062 & 0.022 & 0.254 \\
\hline
\end{tabular}
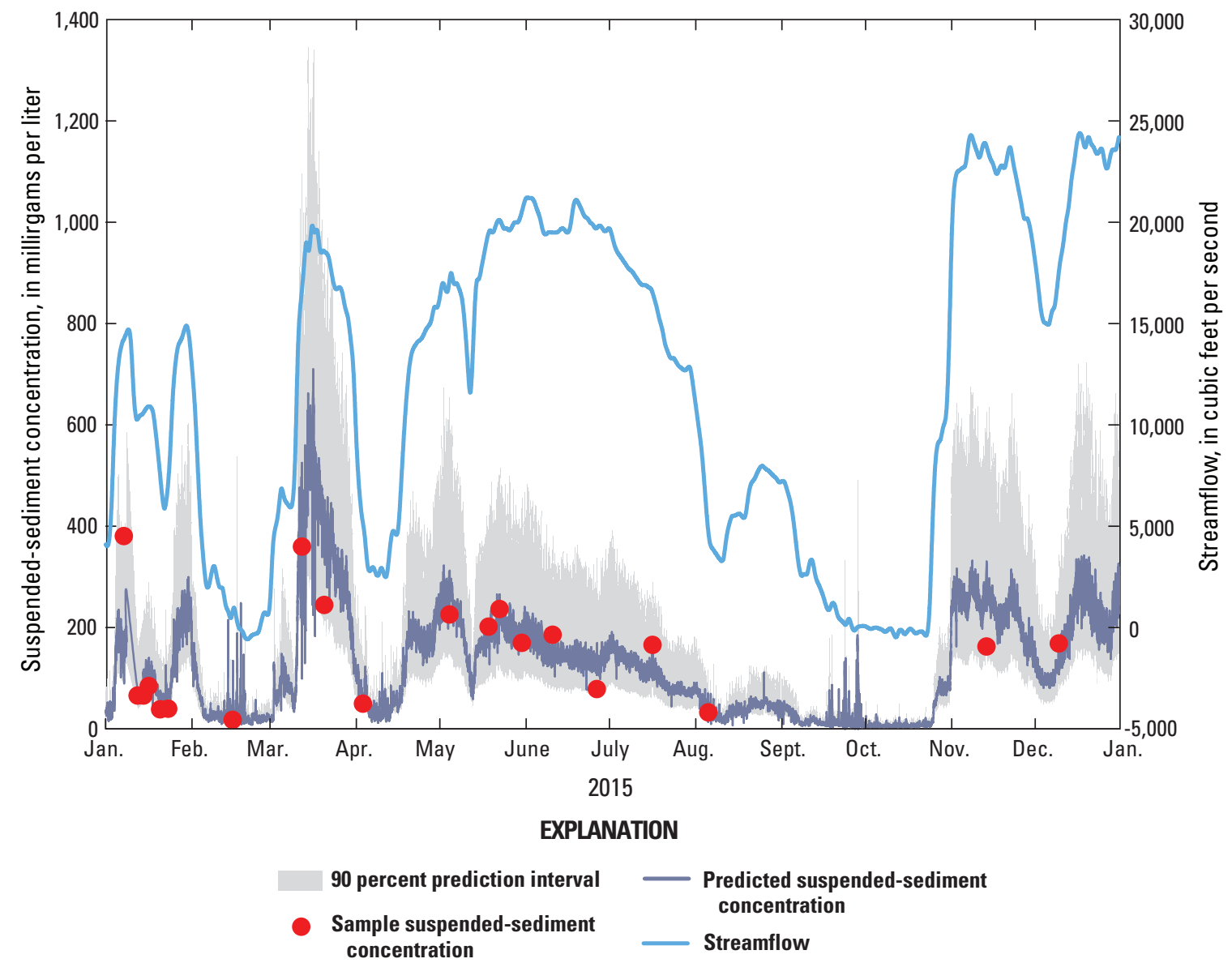

Figure 1-4. Continuous suspended-sediment concentration record at U.S. Geological Survey streamflow-gaging station 08067252 Trinity River at Wallisville, Texas, January-December 2015. 
Publishing support provided by:

Lafayette Publishing Service Center

For more information concerning this publication, contact: Director

U.S. Geological Survey

Texas Water Science Center

1505 Ferguson Lane

Austin, TX 78754-4733

(512) 927-3500

Or visit the Texas Water Science Center Web site at: http://tx.water.usgs.gov/ 


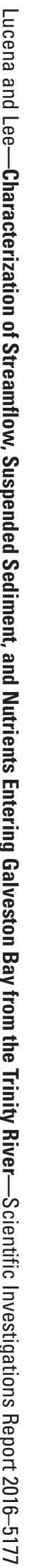

